NBER WORKING PAPER SERIES

\title{
BANKING WITHOUT DEPOSITS: EVIDENCE FROM SHADOW BANK CALL REPORTS
}

\author{
Erica Jiang \\ Gregor Matvos \\ Tomasz Piskorski \\ Amit Seru \\ Working Paper 26903 \\ http://www.nber.org/papers/w26903 \\ NATIONAL BUREAU OF ECONOMIC RESEARCH \\ 1050 Massachusetts Avenue \\ Cambridge, MA 02138 \\ March 2020
}

We thank Anat Admati, Jonathan Berk, Markus Brunnermeier, John Cochrane, Peter DeMarzo, Arvind Krishnamurthy, Amir Sufi, Adi Sunderam, Anjan Thakor, and seminar and conference participants at Berkeley, Colorado, Imperial College London, Kellogg School of Management, Olin, NBER Corporate Finance meeting, Stanford Institute of Theoretical Economics Financial Regulation conference for helpful comments. We also thank Monica Clodius, Cache Ellsworth, and Yilan Zheng for outstanding research assistance. First Version: September 2019. The views expressed herein are those of the authors and do not necessarily reflect the views of the National Bureau of Economic Research.

NBER working papers are circulated for discussion and comment purposes. They have not been peer-reviewed or been subject to the review by the NBER Board of Directors that accompanies official NBER publications.

(C) 2020 by Erica Jiang, Gregor Matvos, Tomasz Piskorski, and Amit Seru. All rights reserved. Short sections of text, not to exceed two paragraphs, may be quoted without explicit permission provided that full credit, including $(\odot$ notice, is given to the source. 
Banking without Deposits: Evidence from Shadow Bank Call Reports

Erica Jiang, Gregor Matvos, Tomasz Piskorski, and Amit Seru

NBER Working Paper No. 26903

March 2020

JEL No. G2,L5

\begin{abstract}
Is bank capital structure designed to extract deposit subsidies? We address this question by studying capital structure decisions of shadow banks: intermediaries that provide banking services but are not funded by deposits. We assemble, for the first time, call report data for shadow banks which originate one quarter of all US household debt. We document five facts. (1) Shadow banks use twice as much equity capital as equivalent banks, but are substantially more leveraged than non-financial firms. (2) Leverage across shadow banks is substantially more dispersed than leverage across banks.(3) Like banks, shadow banks finance themselves primarily with short-term debt and originate long-term loans. However, shadow bank debt is provided primarily by informed and concentrated lenders. (4) Shadow bank leverage increases substantially with size, and the capitalization of the largest shadow banks is similar to banks of comparable size. (5) Uninsured leverage, defined as uninsured debt funding to assets, increases with size and average interest rates on uninsured debt decline with size for both banks and shadow banks. Modern shadow bank capital structure choices resemble those of pre-depositinsurance banks both in the U.S. and Germany, suggesting that the differences in capital structure with modern banks are likely due to banks' ability to access insured deposits. Our results suggest that banks' level of capitalization is pinned down by deposit subsidies and capital regulation at the margin, with small banks likely to be largest recipients of deposit subsidies. Models of financial intermediary capital structure then have to simultaneously explain high (uninsured) leverage, which increases with the size of the intermediary, and allow for substantial heterogeneity across capital structures of firms engaged in similar activities. Such models also need to explain high reliance on short-term debt of financial intermediaries.
\end{abstract}

Erica Jiang

Finance Department

McCombs School of Business

2110 Speedway

Austin, TX 78705

Xuewei.Jiang@mccombs.utexas.edu

Gregor Matvos

Kellogg School of Management

Northwestern University

2211 Campus Drive

Global Hub 4361

Evanston IL, 60208

and NBER

gregor.matvos@kellogg.northwestern.edu
Tomasz Piskorski

Columbia Business School

3022 Broadway

Uris Hall 810

New York, NY 10027

and NBER

tp2252@columbia.edu

Amit Seru

Stanford Graduate School of Business

Stanford University

655 Knight Way

and NBER

aseru@stanford.edu 


\section{Section 1: Introduction}

Traditional banks have substantially more leverage than non-financial firms: the average bank funds almost $90 \%$ of their assets with debt, the vast majority of which is short-term. Capital requirements and other restrictions on bank funding are based on the premise that unconstrained banks would borrow excessively because debt is subsidized through deposits insurance and other safety nets for debtholders. ${ }^{1}$ Because subsidized debt is short term, this further contributes to bank fragility. The extreme version of this view is that banks' capital structure is set up solely to extract subsidies available to financial intermediaries with a bank charter. Intervening in capital structure decisions comes with little social costs, and large benefits to bank stability. The alternative view is that high bank leverage is necessary to efficiently provide financial intermediation services, such as extending loans to households or firms, the creation of safe and liquid debt, or more broadly, for maturity and liquidity transformation. ${ }^{2}$ Tighter capital structure regulations come at the expense of valuable financial services, for example, too little lending to households. Understanding the extent to which subsidies determine bank leverage is therefore essential for setting banking regulation and is a hotly disputed topic.

We approach this question by studying leverage choices of shadow banks. These financial intermediaries provide banking services, but cannot fund themselves with insured deposits, and are not subject to capital requirements. They provide an approximation of how banks would be funded if they did not have access to subsidized deposits nor were subject to capital requirements. We compare their financing structure to banks who engage in similar activities to assess the importance of deposit funding for bank capital structure choices.

To investigate financing choices of shadow banks, we construct, for the first time, shadow bank "Call Reports" from 2011 onwards using the Freedom of Information Act (FOIA) requests from state regulators. We observe detailed balance sheet information the structure of liabilities, both paid in and retained capital, as well as individual credit lines: who provides shadow bank debt, and the amounts drawn. We also observe the asset side of the balance sheets, which we match to the individual loans (mortgages) originated by shadow banks. Our sample comprises more than four hundred largest shadow banks, accounting for about $80 \%$ of shadow bank loans originated during this period, and originating over quarter of all household debt in the U.S.

This paper has two goals. First, we compare the capital structure decisions of shadow banks with those of banks over our sample period and document five main facts about differences and similarities in the capital structures of shadow banks and banks. Second, we discuss some first order implications of these findings for established theories of banking and banking regulation.

Ideally, we would want to compare shadow banks to banks, which engage in similar activities. Shadow banks in our call reports are primarily in the mortgage origination business and sell the

${ }^{1}$ See for instance, Dwyer (1981), Pyle (1984), Admati et al. (2013), Admati and Hellwig (2014), Calomiris and Jaremski (2016), Egan et al. (2017).

${ }^{2}$ See for instance, Diamond and Rajan (2001), DeAngelo and Stulz (2005), Gorton and Pennacchi (1990), Adrian and Shin (2015), Deng et al. (2017). 
majority of the loans they originate. Their business model represents a large fraction of what banks do. Mortgage origination constitutes an important part of bank business: real estate loans account on average for about $80 \%$ of bank loans and half of their assets. Moreover, banks sell the majority of the loans they originate in the mortgage market, as well as in credit cards, auto loans, and corporate loans. ${ }^{3}$ Even at the individual loan level, banks originate mortgages to a similar pool of borrowers as shadow banks. ${ }^{4}$ Nevertheless, to achieve a tighter comparison between banks and shadow banks, we next focus on banks who are primarily in the mortgage origination business and sell the vast majority (over 85\%) of their loans- originate to distribute (OTD) banks. As we show, the construction of the different comparison groups of banks is practically irrelevant. Despite significant differences in the business model and asset holdings across banks, the capitalization differences across banks are tiny relative to the scope of our main facts.

Fact 1: Shadow banks have substantially more equity capital-lower leverage-than banks.

The average equity to asset ratio for banks is approximately $11 \%$. Shadow banks' average asset to equity ratio is more than twice as high at $25 \%$. Only $0.5 \%$ of banks have more capital than the average shadow bank. The more comparable banks-OTD banks-have even less capitalization than the average bank at $10.5 \%$ on average. We find a very robust pattern whether we adjust for differences in lending composition or assets, across bank control groups, and adjusting for risk weights: shadow banks have more than twice as much equity financing than deposit-taking banks, despite no capital requirement for shadow banks. While shadow banks have substantially more capital than banks, it is worth emphasizing that their leverage still substantially exceeds the leverage of non-financial firms, rejecting the idea that banks' capital structure choices would resemble that of non-financial firms in the absence of deposits. Interestingly, the median shadow bank equity capitalization matches well with capital structure of banks in the pre-deposit-insurance era (e.g. Admati and Hellwig 2014, Hanson et al. 2015, Aldunate et al. 2019, Blickle et al. 2019).

\section{Fact 2: Leverage across shadow banks is substantially more dispersed than banks}

Banks leverage is extremely homogenous: the standard deviation in equity to asset ratio across banks is 3 percentage points (pp). Shadow banks' capitalizations, on the other hand, differ widely, with a standard deviation of 18pp. This fact is even more surprising because shadow banks' business models are substantially more homogenous than those of banks. Recall that the shadow banks in our sample are primarily engaged in residential real estate mortgage origination. Banks specialization, on the other hand, can vary substantially as can their asset composition. Some banks may specialize in commercial real estate, others in residential loans, still others in industrial loans or consumer loans. While several of our subsamples directly account for this heterogeneity, the fact remains across various samples we consider: shadow banks are much more capitalized than banks, and the shadow bank capitalization is substantially more dispersed than that of banks.

\footnotetext{
${ }^{3}$ See Buchak et al. (2018) for the similarity in customers of banks and shadow banks in the mortgage market. For banks propensity to sell loans, see Buchak et al. (2019) and Irani et al. (2018).

${ }^{4}$ The average FICO credit score difference between banks' and shadow banks' GSE backed loans is 4 points on the scale ranging from 300 to 850 and the average difference in interest rate is two basis points.
} 
Fact 3: Shadow banks finance themselves primarily with short-term debt and originate long term loans, similar to banks. Shadow bank debt is much more concentrated than bank deposits and is provided primarily by, potentially informed, large banks in the form of credit lines.

Short term debt comprises $85 \%$ of bank debt funding and is largely provided by dispersed uninformed parties (depositors). Shadow banks' debt is almost exclusively (98\%) short-term. Therefore, shadow banks engage in maturity transformation, originating long maturity mortgages using short-term debt funding. On the other hand, the structure of debt differs significantly from banks' debt structure. By definition, all shadow banks debt is uninsured. In comparison, approximately two third of bank deposits are insured. The majority of bank debt is provided by dispersed depositors. Shadow banks debt, in contrast, takes the form of credit lines provided by, on average, 3 to 4 large banks. These results suggest that short-term debt funding is a robust feature of banking irrespective of deposit insurance.

Fact 4: Shadow bank leverage increases substantially with size. Bank leverage, on the other hand, hardly changes with size. Small rather than large banks are significantly undercapitalized relative to their shadow bank counterparts.

As we document above, differences in capitalization across banks are small. This implies that large and small banks have similar equity to asset ratios. In contrast, we document large differences in the capitalization of small and large shadow banks. While both large and small shadow banks have more capital than banks of equal size, the difference is much larger for small institutions. The smallest banks' equity to asset ratios are at least $35 \mathrm{pp}$ lower than those of corresponding shadow. The difference shrinks to 4-8pp for large intermediaries. In other words, small banks are substantially more undercapitalized relative to shadow banks than large banks.

Fact 5: Uninsured leverage, defined as uninsured debt funding to assets, increases with size and average interest rates on uninsured debt decline with size for both banks and shadow banks.

There are two potential reasons why we observe that leverage increases with size of shadow banks, but not banks. One explanation is that the relationship between leverage and size is shadow bank specific, and has little to do with financial intermediation. The second is that the same force is present in banks, but is obscured by banking subsidies and regulation. A substantial share of theories of optimal capital structure require that debt-holders internalize some cost of default, at least off equilibrium. In other words, the theories are about the role of uninsured debt, and have little to say about insured debt. Therefore, the presence of the same frictions in banks would suggest that uninsured debt funding - uninsured leverage-increases with bank size, rather than leverage as whole. We first show that large banks fund themselves with a larger share of uninsured to insured debt than small banks. We then show that uninsured leverage, increases with size for both banks and shadow banks. Therefore, the positive uninsured leverage/size relationship is not a phenomenon unique to shadow banks but extends to banks as well. Second, we find that the average interest rate paid by shadow banks and banks on their uninsured debt decreases with size. This evidence bolsters the idea that the same underlying forces drive uninsured leverage changes 
across banks and shadow banks. This relationship is very robust despite the difference in the type of uninsured debt used by banks and shadow banks.

\section{External Validity: Pre-deposit-insurance banks in U.S and Germany}

Our analysis is based on the idea that shadow banks and banks engage in similar activities, and that the first order difference between these institutions is banks' ability to obtain insured deposits, and accompanying regulatory framework. Then the deviations we observe between modern shadow banks and banks are due to differences in subsidies and regulations. As we argue, we can find several hundred banks who are primarily in the mortgage origination business and sell the vast majority of their loans, making them a good comparison group. We bolster the argument that modern shadow banks differ from banks primarily on their ability to access insured deposits by showing that their capital structure choices resemble those of pre-deposit-insurance banks both in the U.S. and Germany.

We also know from existing literature, that pre-FDIC banks in the U.S. had substantially more capital than modern banks, and much closer to the shadow banks in our sample. Specifically, Aldunate et al. (2019) collect data on more than 6,000 U.S. banks in in 1928, prior to the establishment of the FDIC. We use their data to show that, similar to modern shadow banks, there was substantial dispersion in their capitalization, and their leverage strongly increased with bank size. The same two patterns appear using data from German banks in 1931 collected by Blickle et al. (2019). To summarize, the capital structure of shadow banks in the U.S. post 2011 resembles that of pre-deposit-insurance banks in the U.S. and Germany: they are better capitalized than modern banks, with substantial heterogeneity in leverage across institutions, funded predominantly with short term debt, and leverage increases substantially with size. These patterns suggest that our results are unlikely due to factors, which are specific to shadow banks' business model, the post-crisis period during which we examine them, or the specifics of the modern U.S. in which they operate. Instead, it is much more likely that the differences in capital structures of modern shadow banks and banks are due to differences in subsidies and regulations. This view is also consistent with empirical studies showing that introduction of deposit insurance was associated with a significant increase in bank leverage (see Calomiris and Jaremski 2016, 2019).

\section{Implications}

We conclude by discussing several implications of our facts. Our results suggest that banks' level of capitalization is pinned down by deposit subsidies and capital regulation at the margin. In other words, the most parsimonious model that explains why bank capitalization is about half of shadow banks, and, at the same time why capitalization across banks is so homogenous is the following: banks borrow as much as they can subject to capital requirements, because they have access to subsidized debt funding. ${ }^{5}$ The differences in their capital structure may arise from buffer stock

\footnotetext{
${ }^{5}$ Ratcheting models in the presence of capital requirements can also lead all banks to choose capital levels close to the constraint and leave them with heterogeneous and lower capitalization in the absence of such requirements (see DeMarzo 2019).
} 
considerations (e.g., as in Corbae and D'Erasmo 2018). Shadow bank leverage, however, still substantially exceeds that of non-financials, suggesting that intermediary incentives to fund with (short term) debt are high, even in the absence of subsidies. Because of the extent of the deposit subsidies, however, these incentives are infra-marginal for banks, especially small ones.

Shadow banks' capital structure also reveals the extent to which financial intermediaries are fundamentally "special," i.e. different from non-financial firms. Our results indicate that financial intermediaries are special in two ways: They are funded with substantially more debt than nonfinancials, and rely almost exclusively on short term debt funding. Two other features of bank financing: homogeneity in capital structure, and predominantly dispersed (uninformed) debt, on the other hand, are not robust features of intermediary funding, and likely arise as a consequence of subsidies and regulation. Last, the funding of financial intermediaries' mirrors that of nonfinancial firms in important ways: substantial intra-industry heterogeneity in capital structure, and an increase in (uninsured) leverage with size.

Model of financial intermediary capital structure then have to simultaneously explain high (uninsured) leverage, which increases with the size of the intermediary, and allow for substantial heterogeneity across capital structures of firms engaged in similar activities. Such models also need to explain high reliance on short-term debt of financial intermediaries.

It is difficult to pin down a specific factor, which is responsible for the substantially higher leverage of financial intermediaries relative to non-financial firms. In standard corporate finance models, endogenous leverage reflects various frictions (e.g., Townsend 1979; Diamond 1984; Bolton and Scharfstein 1990; Holmstrom and Tirole 1997; Hart and Moore 1998; DeMarzo and Fishman 2007). Viewed through the lenses of such models the high leverage of financial intermediaries would imply, on average, less risky cashflows or less intense underlying frictions (e.g., monitoring costs, liquidation costs) of financial intermediaries relative to non-financial firms. High leverage of financial intermediaries could be also a byproduct of liquidity production (e.g., see Diamond and Dybvig 1983; Allen and Gale 1998; DeAngelo and Stulz 2015). Such arguments could apply to shadow banks we focus on if one would consider their short-term warehouse credit line debt as a relatively liquid form of investment from the creditors (large banks) perspective.

Our findings point to predominance of short-term debt funding structure among financial intermediaries irrespective of their access to deposit funding. First, the short-term financing could serve as a disciplining device for financial intermediaries (e.g., Calomiris and Kahn 1991; Diamond and Rajan 2001). Since shadow bank debt is highly concentrated and provided by potentially informed lenders (large banks), the broad message of monitoring resonates. However, to the extent the short-term debt indeed plays such role, our findings point out that the fragility induced by highly dispersed (and potentially uninformed) debtholders is not an essential component of such monitoring function. Second, the short-term nature of debt can also facilitate liquidity production, which is viewed as intrinsic function of banking (Diamond and Dybvig 1983; Gorton and Pennacchi 1990; Holmström and Tirole 1998; Diamond and Rajan 2001). Finally, 
contractual externalities among multiple creditors can also result in short-term debt maturity structures (e.g., Brunnermeier and Oehmke 2013).

We document that intermediary (uninsured) debt increases with size. The relationship between interest rates and size can help narrow the scope of potential explanations behind this effect. If uninsured leverage of intermediaries increases in size, then either the benefits of uninsured leverage increase with size, or the costs of uninsured debt financing decline. The declining rates certainly suggest that lenders perceive larger intermediaries, both banks and shadow banks to be safer. One possible driver of this effect could be lower cashflow risk due to risk diversification benefits that increase with size as in Diamond (1984), although measures along these two dimensions do not explain the entirety of the size effect. Viewed through the lens of trade-off models and capital structure models with frictions, our results are also consistent with higher bankruptcy (liquidation) costs, more intense agency frictions or higher monitoring costs for smaller financial intermediaries relative to larger ones. Finally, the substantial heterogeneity across capital structures of shadow banks engaged in similar activities is also consistent with models where leverage is dependent on the history of the firm's realized cashflows (e.g., DeMarzo and Sannikov 2006; DeMarzo and Fishman 2007; Bias et al. 2007; Bolton et al. 2011; He and Krishnamurthy 2011; Brunnermeier and Sannikov 2014; DeMarzo and He 2016; Admati et al. 2018).

Our results also have broad regulatory implications. At its core, regulating bank capital structure trades-off bank stability with ability to finance intermediary activities, such as lending. Our results suggest that when this tradeoff is made by the largest shadow banks, they choose to fund themselves with an average equity to asset ratio of about $17.5 \%$, which is significantly above the current capital requirements for banks. This result suggests that capital requirements do not constrain lending beyond the level chosen by intermediaries without access to deposit subsidies. This observation is also consistent with relatively modest effects of higher capital requirements on aggregate lending volume (Buchak et al. 2019). For substantially higher capital requirements, however, the tradeoff between banks' ability to finance their lending and externalities caused by bank failures may become much more binding.

Second, bank regulations are often dependent on size. Capital requirements, FDIC assessment rates, as well as other forms of regulation are frequently stricter for large banks. We find that the banks' deviation in capital structure choices from those of shadow banks are largest for small banks. Therefore, our results suggest that it is the small banks, which benefit most from the insured deposit subsidy. If this is indeed the case, then, size-based regulations have to be more closely targeted to the frictions they are supposed to resolve. If regulations are in place to prevent spillovers from the failure of banks, then regulations should be stricter for large, and especially systemically important, banks. On the other hand if regulation and implicit taxes on funding are in place to offset deposit subsidies, then our results suggest these should be stricter for smaller banks. 


\section{Institutional Background: Banks vs. Shadow Banks in U.S. Mortgage Market}

Loans are either originated by banks or by shadow banks. Banks as deposit taking corporations, and shadow banks are non-bank lenders. This definition is consistent of the Financial Stability Board, whose members comprise both national regulators of G20 countries, as well as international financial institutions, such as the International Monetary Fund, the World Bank, and the Bank of International Settlements, as well as international standard-setting and other bodies such as the Basel Committee on Banking Supervision. (see Buchak et al. 2019). Deposit taking of banks exposes them to a substantially higher regulatory burden than shadow banks. For example, banks are subject to capital requirements, enhanced supervision from a wide set of regulators, such as the FDIC, FED, OCC, and state regulators, as well as extensive compliance and rules. Shadow banks face limited supervision and regulation, primarily from state regulators.

Our main exercise is to compare the funding structure of shadow banks to banks. Ideally, we would like to compare banks and shadow banks that engage in similar activities. Shadow banks we focus on are in the mortgage origination business and sell the majority of the loans they originate. Banks, on the other hand, engage in a broader set of activities, for example, also providing loans to corporations. Here we compare the business models of shadow banks to those of banks on several key dimensions and show that despite some differences banks and shadow banks engage, on average, in similar activities. When we compare shadow banks to banks in the rest of the paper, we narrow that comparison further by focusing on the banks with the most similar business models to shadow banks.

\section{Lending and Assets Composition}

Lending is a major part of the business for both banks and shadow banks. Loans extended by both types of intermediaries are the largest item on their balance sheet accounting, on average, for a very similar portion of their assets. Using the call report data, which we discuss in the next section, we find that on average loans constitute about $67 \%$ of shadow bank assets, which is very close to $65 \%$ for banks (see Appendix A1, panel a). Since shadow banks specialize in mortgage lending, real estate loans constitute, on average, close to $100 \%$ of loans on the balance sheet. However, even for the average bank, about $80 \%$ of loans on the balance sheet are real estate loans. Moreover, residential mortgage loans are the most common category of real estate loans for both banks and shadow banks (for shadow banks, a vast majority of their loans are residential real estate loans).

\section{Propensity to Sell Loans and OTD model}

Shadow banks sell more than $90 \%$ of their loans (Appendix A1, panel b), relying primarily on the originate-to-distribute (OTD) business model. Despite a common perception that banks hold on to the loans they originate, banks also sell the majority of their loans (Buchak et al. 2019), including about $60 \%$ of the residential real estate loans (Appendix A1, panel b). Moreover, while these are averages, Buchak et al. (2019) find that a substantial share of banks has a similar originate-todistribute (OTD) business model to shadow banks. As we discuss below, we leverage on this observation and compare the capital structure choices of shadow banks to high OTD banks - those 
that sell about $90 \%$ of their loans -- to better account for differences in business models across intermediaries. There are more than half a thousand of such high OTD banks that, like shadow banks, sell almost all loans they originate.

\section{Borrower and Loan Characteristics}

Shadow banks and banks compete head to head for the same borrowers in the same markets and offer similar contract terms over our sample period (see Buchak et al. 2018). Appendix A1 (panel b) compares the borrower characteristics for bank and shadow bank loans. Over the period 2011 to 2017 , banks and shadow banks serve borrowers with similarly sized mortgages ( $\$ 253 \mathrm{~K}$ versus $\$ 225 \mathrm{~K}$ on average) and broadly similar incomes ( $\$ 129 \mathrm{~K}$ versus $\$ 101 \mathrm{~K}$ on average).

To illustrate further the similarity of loans and borrowers across banks and shadow banks, we also use detailed data for the most common loan type during our sample period, those sold to GSEs, which comprise more than half of all loan originations. For such loans, due to GSE data disclosure, we can see detailed borrower and contract level information. We present the results in Appendix A1 (panel c). Borrowers' creditworthiness is very similar, with average FICO score of 755 for shadow bank borrowers and 759 for bank borrowers. ${ }^{6}$ Moreover, these borrowers have very similar average LTV ratios (71.3 versus 71.9 percentage points), debt to income ratios (33.5 versus 32.9 percentage points), interest rates (4.01 versus 3.99 percentage points). Finally, borrowers served by both types of lenders have also very similar average loans amounts ( $\$ 240 \mathrm{~K}$ for shadow banks versus $\$ 231 \mathrm{~K}$ for banks). Overall, this evidence confirms that in the main mortgage market shadow banks and banks serve very similar borrowers and offer very similar loan terms.

\section{Constructing Shadow Bank Call Reports}

\section{A Constructing Shadow Bank Call Reports through FOIA}

We construct a novel data set containing balance sheet information of shadow banks in the US residential mortgage origination market from 2011 to 2017. We use FOIA requests to collect data from shadow banks' quarterly call report filings to state regulators. Pursuant to the S.A.F.E. Mortgage Licensing Act of 2008, shadow banks that hold a state license or state registration to conduct mortgage origination are required to file a call report in each state in which they perform lending activities since 2011. We access these data through FOIA requests of Washington and Massachusetts, the two states, which complied with our request out of all 51 states we sent requests to. As long as a shadow bank is registered or licensed in either of these states, we obtain information on all its operations across all states. Therefore, as we describe below, even sampling two states allows for extensive coverage, especially among the largest shadow banks.

Each shadow bank has a unique ID in the National Mortgage License System (NMLS ID), which is used as an identifier in the call reports. The call report contains two components, Financial Condition (FC) and Residential Mortgage Loan Activity (RMLA). The FC collects data on the

\footnotetext{
${ }^{6}$ These borrowers also have very similar delinquency rates (Buchak et al. 2018).
} 
balance sheet and the income statement at the company level. The RMLA contains detailed information about individual debt facilities. For each debt item, we observe the provider (lender) name, the credit limit, and the amount of remaining limit that has not been drawn on each credit line. Together these components allow us to construct "call report" information for shadow banks in our sample.

Because the majority of lending is done by large shadow banks, which are registered in practically all states, including Massachusetts and Washington, we cover a substantial share of the shadow bank mortgage market. Not surprisingly our sample overweighs large shadow banks. ${ }^{7}$ We combine our sample of shadow banks with loan level data from Home Mortgage Disclosure Act (HMDA), which has information on mortgage originations of virtually all lenders in the economy. In particular, HMDA data collects the vast majority of mortgage applications in the United States, along with their approval status. In addition to the application outcome, the data includes loan type, purpose, amount, year of origination, and location information down to the applicant's census tract. It further contains demographic information on the applicant, including race and income. Important for our analysis, it includes the originator's identity, which we link manually across years. Finally, it documents whether the originator sells the loan to a third party. ${ }^{8}$

We link the HMDA data with shadow bank call report data. Each shadow bank has a unique ID in the National Mortgage License System (NMLS ID), which we use as identifiers in the call reports. The NMLS ID is not publicly disclosed in the HMDA database. Instead each financial intermediary has institution ID. To link the two data sets, we construct a crosswalk table by using the NMLS Consumer Access platform, where consumers can search for shadow bank registration information using company name and address.

Our merge results in 429 shadow banks for whom we have complete call report and HMDA information. These shadow banks originated about \$4 trillion of residential mortgages from 2011 to 2017. This is substantial origination volume and accounts for about a third of all mortgage originations during this period.

In our analysis we compare shadow banks with banks. The data on bank capital structure and interest expenses are obtained from bank regulatory call report filings, Form 031 and Form 041, publicly available on the Federal Financial Institutions Examination Council (FFIEC) website. Since the regulatory filing requirements changed several times post crisis, we check the historical 031 and 041 forms year by year to ensure the consistency of our data.

\section{B Shadow Bank Call Reports: Coverage and Representativeness}

To evaluate our coverage, we also compare the origination volume by shadow banks in our sample with total shadow bank mortgage originations in HMDA data. This allows us to understand which

\footnotetext{
${ }^{7}$ As we show later, capital structure of large banks is more similar to that of shadow banks. Thus our sample averages understate the differences between shadow banks and banks.

${ }^{8}$ An important caveat with the sales data is that if the originator retains the loan through the end of the calendar year and sells it in the subsequent year, it is recorded in HMDA as a non-sale.
} 
shadow banks are missing from our data, because they did not originate in Washington or Massachusetts. Figure 1 (Panel a) compares the origination volume by shadow banks in our sample to origination volume by all shadow banks over time. Except for 2011, about $80 \%$ of total shadow bank mortgage origination in each year is covered by shadow banks in our sample. The pattern in 2011 is not surprising. Since the call reports were not enforced in Massachusetts in 2011, our sample coverage in 2011 is not as comprehensive as in later years. Even so, our sample still covers more than $40 \%$ of the total shadow bank origination in 2011.

Panel (b) of Figure 1 compares the distribution of loan volume by shadow banks in our sample to the entire shadow bank population recorded by HMDA in 2017. Our data contains most shadow banks on the right tail of the entire shadow bank size distribution. As an alternative check, we find that we cover 171 out of the 240 largest U.S. shadow banks identified in Buchak et al. (2018), and observe all shadow banks among the top 10 mortgage lenders in 2017. Small local shadow banks in states other than Washington and Massachusetts are underrepresented. Our call reports miss 464 small shadow banks in in 2017, which comprise approximately $20 \%$ of mortgage origination, and originate on average $\$ 371$ million.

\section{C Summary Statistics: Shadow Bank Assets, Liabilities, Income, Expenses, and Debt Facilities}

We use the two components (FC and RMLA) to present summary information on asset and liability side for shadow banks in our sample. In Table 1 we provide a summary of asset composition, and income and expense composition for shadow banks, averaged across our sample period (2011: Q1 to 2017 Q4). Table 2 provides information on liability and equity composition as well as information on debt providers for shadow banks, averaged, over the same time period.

Assets: In Panel (a) of Table 1 we display the detailed composition of assets for 429 shadow banks in our sample, averaged over our sample period. Here, we list the major categories. As one would expect, the largest asset categories are mortgage related: Mortgages held for sale comprise $64 \%$ of assets; Mortgages held for investment around 4\%; Mortgage servicing rights comprise another $7.5 \%$ of assets. We also have information on other assets. The largest categories are Cash, which comprises $11.7 \%$ of assets, Receivables comprise $3.25 \%$ of assets, Buildings and properties another $2 \%$ and Derivatives' comprising $1.4 \%$.

Liabilities: The liabilities side of the balance sheet contains detailed information on the financing structure of shadow banks. We explore the liabilities structure of shadow banks in substantial detail the body of the paper. In Panel (a) of Table 2, we provide some simple statistics. Equity capital accounts for about $25 \%$ of assets of shadow banks in our sample, averaged over the sample period. Almost half of this equity capital is from retained earnings and the rest is largely from common stock and paid-in capital. We also observe the composition of non-equity long-term and short-term liabilities, that together account for $75 \%$ of assets. Virtually all liabilities of shadow banks are short-term (about 90\%), with short-term debt accounting for majority of this category. Since shadow banks have no deposits, all debt is uninsured. 
Debt Facilities: We have detailed information on individual debt facilities in our data. For each debt item, we observe the provider (lender) name, the credit limit, and the amount of remaining limit that has not been drawn on each credit line. As discussed above, a substantial portion of debt of shadow banks is short-term debt. Panel (b) of Table 2 shows that this funding comes in the form of warehouse lines of credit provided, on average by around 4 lenders (median 3 lenders). These warehouse lines of credit are credit lines which are secured with the mortgages originated by the lender, and generally have to be repaid in less than a year. Lenders to shadow banks fall into two categories, banks, such as Credit Suisse First Boston, JPMorgan Chase, and Bank of America that provide about $93 \%$ of available credit line funding and non-bank financial institutions providing the rest. For a more detailed analysis of credit lines to shadow banks, see Jiang (2019). Interestingly, shadow banks draw only about half of the available credit lines (50.3\%) over the sample period.

Income and Expenses: Panel (b) of Table 1 shows the composition of income and expense statement of shadow banks in our sample, again, averaged over the sample period. Sales of mortgages in the secondary market and origination related income (e.g, fees) account for about $74 \%$ of shadow bank gross income, with secondary market sale accounting for about three fourths of it. This tilt reflects the fact that vast majority of mortgages originated by shadow banks are subsequently sold in the secondary loan market (see Buchak et al 2018a, b). Mortgage servicing fees account for about $9 \%$ of gross income, in large part due to retaining servicing on significant portion of mortgages sold. On the expense side, personnel expenses account for about $56 \%$ of all expenses. Interest expenses account for about $7 \%$ of total expenses of which a large part is interest payment on warehouse credit lines.

\section{D Regulatory Capital for Shadow Banks}

Shadow banks are not subject to capital requirements, and are thus not required to report regulatory measures of capital, or to use risk-weights when evaluating the amount of capital. Since a large part of our analysis focuses on comparing the capital structure of banks and shadow banks, including regulatory measures of capital, we need to construct regulatory capital equivalents for the Tier 1 capital for each shadow bank in our sample.

There are two components to constructing regulatory measures of capital for shadow banks. First, we compute the Tier 1 capital, by adding up common stock, paid-in capital, retained earnings, preferred stock, and noncontrolling interest. Second, we need to construct risk weighted assets. However, we have insufficient information to construct precise risk weighted assets. ${ }^{9} \mathrm{We}$ address this limitation by constructing bounds on risk weighted assets using the range of weights.

The lower bound of the risk-weighted assets assigns $20 \%$ to residential mortgages that are guaranteed or insured by the government (FHA, VA, or RHS), 50\% to non-government insured mortgage loans, $250 \%$ to mortgage servicing rights, $0 \%$ to cash, securities, deferred tax assets, and goodwill and other intangible assets, and $100 \%$ to all other assets, such as receivables and property,

\footnotetext{
${ }^{9}$ We do not observe the exact proportion of Category 1 and Category 2 residential mortgage loans.
} 
equipment and other fixed assets. The upper bound is computed by assigning $100 \%$ weight to nongovernment insured mortgage loans while assigning the same weights as in the calculation of the lower bound on all other assets. We then compute the upper (lower) bound of the asset risk weighted tier 1 capital ratio by dividing the tier 1 capital by the lower (upper) bound of the riskweighted assets.

\section{E Comparable Bank Samples}

The central exercise in the paper is to compare the funding structure of shadow banks to banks. Ideally, such a comparison would use banks, who engage in identical activities as shadow banks. The primary activities of shadow banks in our sample are mortgage lending and servicing, with shadow banks selling the majority of their loans. Banks, on the other hand, engage in a broader set of activities besides mortgage lending and servicing. As we discuss in Section 2, banks and shadow banks are not fundamentally different either in the loans they originate, nor whether they hold these loans on their portfolio. In addition, as Figure 2 (a) and (b) show, there is a substantial overlap in our sample of shadow banks and sample of all banks when we compare them on loan volume and on assets. Having said that, there are differences in the business model of the average bank and average shadow bank. We therefore focus on several comparable sets of banks that mimic shadow banks more closely.

As we show in Sections 4 and 5, the choice of the comparison group of banks turns out to be irrelevant. Despite significant differences in the business model and asset holdings across banks, the capitalization differences across banks are tiny relative to the scope of our main facts. Nevertheless, it is useful to illustrate this fact empirically. Our first two comparison sets focus on banks, which are a closer match for shadow banks, because they are predominantly focused on selling their loans, rather than keeping them for portfolio reasons. In other words, just like shadow bank, they follow the OTD business model. Accordingly, we construct two sets of banks "OTD I" and "OTD II."

The OTD I sample focuses on banks' mortgage lending. These banks are in the top five percent of all banks in the share of mortgages sold in a given year. We obtain this information from HMDA, which tracks loans sold within a year for every lender. Banks in aggregate sell approximately $60 \%$ of retail mortgages (Appendix A1). The average OTD I bank sells about 92.4\%, which is very close to the corresponding percentage for shadow banks which is $94.4 \%$. There are 549 banks in this subsample. The minimum percentage of loans sold for any OTD I banks is $85.5 \%$.

OTD II banks are also selected based on selling of loans, but are not restricted to residential mortgages. We use bank call report and select banks whose shares of loans held for sale (out of total loans held on balance sheet) that are greater than $10 \%$. Loans, which are sold spend much less time on the balance sheet than loans held for investment. Note that, under some reasonable assumptions, ${ }^{10} 10 \%$ rate of is broadly consistent with the minimum $85.5 \%$ of mortgages sold out

\footnotetext{
${ }^{10}$ Suppose loans retained on balance sheet have an effective maturity of 5 years (60 months) due to refinancing and prepayments, but mortgages held for sale are held on the balance sheet for about 1 month (consistent with Buchak et 
of total originations threshold that we had for banks in OTD I set. Indeed, as we show in Appendix A1, about $89 \%$ of mortgages originated by OTD II banks are sold. There are 257 banks in this comparison set. Appendix A2 shows the relation between the measures used to construct the variants of "OTD" banks. It confirms that banks selling almost all their mortgage loans have on average loans held for sale to total loans ratio in excess of $10 \%$.

We also construct "synthetic mortgage banks" as another comparison group to mimic mortgage activities of shadow banks. The idea is the following. Suppose mortgage activities require different types of funding than non-mortgage activities. Then banks, which are primarily engaged in mortgage lending should have different capital structures than banks, which are engaged in other activities. We then use variation across banks to extrapolate what the capital structure of banks would be if they only engaged in mortgage activities. We estimate the following specification:

$$
\text { Ratio }_{i}=\alpha+\beta \text { MortgageShare }_{i}+\Gamma X_{i}+\epsilon_{i}
$$

In which MortgageShare $_{i}$ is the residential mortgage asset share of total assets, and $X_{i}$ includes the logarithm of total assets, cash to total assets ratio, security to total asset ratio, fixed assets to total assets. More importantly, it also includes non-residential real estate asset to assets, commercial and industrial loans to assets, agricultural loans to assets, individual loans to assets, and other loans to assets. The dependent variable, Ratio $_{i}$ is different capital structure ratios such as equity to assets. This specification is then used to construct capital structure ratios of "synthetic banks" that mimic shadow banks -- those whose total assets are entirely made up of mortgage loans. To do so, we compute the predicted $\widehat{R a t l o}_{\imath}$ for each bank while assigning 100-percent weight on mortgage assets and zero on other assets, i.e.

$$
\widehat{\operatorname{Ratlo}}_{\iota}=\alpha+\hat{\beta} \times 100 \%+\widehat{\Gamma} X_{i}+\widehat{\epsilon}_{l},
$$

Our third comparison set has 4,822 synthetic mortgage banks. Notably, we also conduct robustness in how we construct the capital structure ratios for synthetic banks. In particular, we compute MortgageShare $_{i}$ and controls as a function of total loans, rather than assets. That is, MortgageShare $_{i}$ in this specification is now residential mortgage to total loan ratio, and $X_{i}$ includes commercial and industrial loans to total loans, agricultural loans to total loans, individual loans to total loans, and other loans to total loans. Similar to the procedure above, we compute the alternative synthetic comparison group of mortgage banks by replacing all bank loans with mortgage loans while keeping all other assets fixed. We obtain very similar results with this alternative synthetic bank comparison group.

al. 2018). The share of loans held for sale is $10 \%$ out of total loans on balance sheet in a given month. Then, about $86 \%=[1 /(1+(1$ month $/ 60$ month $\times 90 \%))]$ of loans are sold out of total loans originated in that month. 
Finally, we also compare key funding ratios of shadow banks to all the banks ("All Bank" or "Full Bank" sample), regardless of their exposure to activities done by shadow banks.

\section{Section 4: Shadow Bank and Traditional Bank Capitalization}

In this section, we document three facts about how the capital structure of shadow banks compares to that of banks. The idea behind this exercise is simple. Shadow banks perform similar activities to banks, but do not enjoy access to subsidized deposits. Nor are shadow banks subject to capital regulation. We therefore view capital structure choices of shadow banks as indicative of what bank capitalization would be in the absence of deposit insurance and capital regulation. We document two main facts about the difference in capitalization between banks and shadow banks, and one fact about the structure of debt funding.

\section{A Fact 1: Shadow Banks Have Substantially More Capital-Lower Leverage-than Banks}

We start by measuring capitalization - the central measure of bank leverage — of shadow banks and comparing it to banks. Table 3, Panel (a) shows the bank and shadow bank liability and equity composition. Shadow banks have a mean equity to asset ratio equal to $25 \%$. The average bank, on the other hand, has capital of $11 \%$. Since capital regulation is frequently interested in the tradeoff between lending and bank stability, it may also be informative to weigh institutions by the number of loans they originate. The average shadow bank mortgage is originated by a shadow bank with $21 \%$ equity to asset ratio, while the average bank mortgage is originated by a bank with a $11 \%$ equity to capital ratio. In other words, the average shadow bank in our sample funds with over twice as much equity as the average bank.

As we discuss above, one possible concern is that shadow banks sell loans at a higher rate than the average bank, which could be driving the lower capitalization of banks. The data suggests that if anything, the opposite is the case. Banks, which sell more loans are on average less capitalized than other banks, with OTD I banks capital representing $10.2 \%$ of their assets, and $10.5 \%$ for OTD II banks (see Buchak et al. 2019). Therefore, if we compare the capitalization of shadow banks to that of banks, which primarily engage in the same activity, OTD I and OTD II banks, the differences between banks and shadow banks become larger. These results also suggest that the choice of the bank comparison group does not matter: the differences in capitalization between different groups of banks are on the order of $1 \mathrm{pp}$, whereas the difference in the capitalization of banks and shadow banks is around 14pp. The broad point that emerges here is that, regardless of the comparison set, shadow banks have a substantially higher equity capital in their funding structure relative to banks.

Another way to see the disparity between the capital of banks and shadow banks is in Figure 3 and 4 where we focus on the distribution of capital, rather than the average. Figure 3 illustrates the distribution of equity to asset ratio among shadow banks and banks in various comparison sets (see also panel (b) of Table 3). Figure 4 illustrates changes across time. The magnitude of disparity becomes clear when one realizes that only very few (fewer than $0.5 \%$ ) banks have equity capital large than shadow bank average of $25 \%$. Figure 4 suggests that these differences are not driven by 
shadow banks' explosive growth during this period. ${ }^{11}$ The average difference in capitalization of banks and shadow banks was similar at the beginning of the growth period, in 2011, as after, in 2017.

What we have shown so far are simple univariate comparisons. Figure 3 illustrates that banks, which are primarily tilted towards the mortgage origination business and which predominantly sell their loans (panel b-d) have on average very similar leverage to other banks. Thus, it is difficult to see which characteristics could drive a bank to $25 \%$ capitalization. Nevertheless, to formally account for differences in composition of banks and shadow banks that might drive their capitalization, we estimate a more the following specification:

$$
C_{i, t}=\alpha+\beta_{1} \text { ShadowBank }_{i}+X_{\mathrm{i}, \mathrm{t}}^{\prime} \Gamma+\mu_{t}+\epsilon_{i, t},
$$

where $C_{i, t}$ (capitalization) is the equity to asset ratio of institution $i$ at time $t$. The key variable of interest is the shadow bank indicator, ShadowBank $k_{i}$, that takes the value of one if a lender is shadow bank and is zero otherwise. $X_{i, t}$ contains institution and local economic controls. These include the lender's growth (asset growth), the share of refinanced loans out of total loan origination portfolio, the share of government-insured loans out of total loan origination portfolio, the logarithm of annual mortgage volume in dollars, the logarithm of asset size in dollars and the logarithm of the weighted average of income per capita in states of operation of the institution, and a measure of geographic dispersion (diversification) of residential lending activity. ${ }^{12}$ In addition, $\mu_{t}$ is the time fixed effect (year-quarter) which accounts for any time specific shocks that may impact capitalization ratios of all lenders. We estimate this specification across four different bank samples: the sample of all banks, OTD I, OTD II, and synthetic banks, and present the results in Table 4.

The results from the regression mirror those from the simple cuts of the data. On average, even adjusting for differences in their lending and portfolios, shadow banks have between 10pp and $12 \mathrm{pp}$ higher capital ratio than banks across comparison samples. These estimates confirm the simple cuts of the data, suggesting that shadow banks have about twice as much capital as corresponding banks. These results also confirm our intuition that differences in characteristics between banks and shadow banks cannot explain the differences in their capitalization. One diagnostic of how little controlling for observable characteristic matters is to compare the differences in the raw means of shadow banks and banks to the coefficients from the table. The difference is at most 1.6pp, suggesting that controlling for differences between banks and shadow banks has little impact on the estimates. As we noted in Section 2, mortgage market undergone significant changes during our sample period, including more than doubling of shadow bank market share in originations (Buchak et al. 2018). Yet, the addition of time fixed effects barely

\footnotetext{
${ }^{11}$ The patterns shown in Figure 4 are also not driven by changes in sample composition over time. We obtain very similar results when we restrict our attention to shadow banks and banks that are present during our entire sample period.

${ }^{12}$ The geographic dispersion of a lender is measured by the sum of squares of mortgage origination share in each county for that institution.
} 
changes the coefficient estimates, confirming the intuition from Figure 4 that the differences are not isolated to a specific time period.

While capitalization (leverage) of banks is interesting in itself, regulatory attention is frequently focused on risk-based capital ratios. Shadow banks do not report risk-based tier 1 capital ratios. As we noted in Section 2.D, we apply Basel III guidelines and construct risk-based tier 1 capital ratio for shadow banks. Because we do not observe the detailed risk profiles for each type of assets held on shadow bank balance sheet, we calculate the upper bound and lower bounds of tier 1 capital ratio for shadow banks. Figure 5 mimics Figure 3 for different comparison groups of banks and plots tier 1 capital ratios for banks and shadow banks. As before, we continue to find that shadow banks have a significantly higher tier 1 capital ratio relative to banks, even when we apply an extremely stringent lower bound. The lower bound shadow banks' average Tier 1 capital ratio is $29 \%$, while the upper bound is $37 \%$. Even the lower bound substantially exceeds the $16 \%$ average Tier 1 ratio of banks, and the $15 \%$ capital ratio of OTD I and OTD II banks. It even exceeds the synthetic banks Tier 1 capital ratio of $21 \%$.

We formally test this by re-estimating the regressions from Table 4 but using the upper and lower bound of Tier 1 capital ratios as dependent variable instead. Table 5 shows these results. Even at the lower bound and across subsamples, we find that shadow banks are better capitalized than banks. Overall, across all specifications, controls, subsamples, and different ways of measuring capital, we find a very robust pattern: shadow banks have, on average, significantly more equity in their capital and hence much lower leverage than deposit-taking banks.

\section{B Fact 2: Differences in Capitalization across Shadow Banks' are Substantially Larger than those Across Banks}

Banks differ in the sectors to which they lend: some banks tilt substantially to commercial real estate, others towards residential loans, still others to industrial loans or consumer loans. Banks' capitalization is remarkably homogenous despite large differences in their business models, which differentiates them from non-financial firms (Hanson et al. 2015). Another way to state the same fact is that differences in activities on the asset side do little to pin down a specific leverage ratio of banks. If activities on asset side were driving the homogeneity on capital structure decisions of intermediaries, we would observe an even higher amount of homogeneity in the capital structures across shadow banks. The reason is that shadow banks in our sample are substantially more homogenous in their business model, with all focused on retail mortgage origination and OTD. This is not the case in the data. One potential explanation of homogenous capital structure of banks is that target leverage is a first order determinant of banks' value generation (Egan et al. 2019). Therefore, the equilibrium amount of leverage across banks is similar.

We first confirm that bank capitalization is quite homogenous, with a standard deviation of equity to asset ratio of 2.9pp. In Table 3, Panel (b), we focus on the equity to asset ratio for shadow banks and banks in the four comparison groups. We report the asset weighted mean, volume weighted mean, simple mean as well as various percentiles of this ratio. The dispersion in shadow bank capitalization exceeds that of banks by over 6 times, with the standard deviation of $18.3 \mathrm{pp}$. Thus, 
despite more homogenous business models, there is significantly more dispersion in capital ratio across shadow banks relative to banks.

This simple statistic could in principle mask substantial heterogeneity across banks. For example, we have 549 OTD I banks, which are more comparable to shadow banks in terms of their business model. It is possible that the capital structure of these banks is substantially more dispersed than that of other banks, but because they are pooled with all banks, their contribution to overall variance is small. Figure 3 shows this is not the case visually. The differences across OTD I and OTD II banks' capitalizations are small relative to the differences across shadow banks.

Second, it is possible, although not likely, that differences across business models or activities of shadow banks are larger than those across banks, despite strong prima facie evidence to the contrary. We address this concern by estimating differences across the capitalization of shadow banks and of banks using the following specification:

$$
C_{i, t}=\alpha+X_{i, \mathrm{t}}^{\prime} \Gamma+\mu_{i}+\mu_{t}+\epsilon_{i, t}
$$

where $C_{i, t}$ is the equity to asset ratio of institution $i$ at time $t . X_{i, t}$ contains institution and local economic controls, $\mu_{t}$ contains time fixed effects, and $\mu_{i}$ contains institution fixed effects. We estimate this specification separately for banks and shadow banks.

The object of interest is the distribution of institution fixed effects. $\mu_{i}$ measures the time invariant difference in the capitalization of an institution relative to other institutions, controlling for differences in their characteristics (business models) and time. If the fixed effects of shadow banks are more dispersed than those of banks, it confirms that there are larger differences across shadow banks capitalization, even once we condition on differences across them. Fixed effects are measured with error, so differences in their dispersion across banks and shadow banks could be

driven by differences in measurement error. To avoid this concern, we estimate empirical Bayes fixed effects, which account for measurement error, and plot the distribution of fixed effects in Appendix A3.

As is clear from Appendix A3, even once we account for differences in observable characteristics within the samples of banks and shadow banks, the differences in shadow bank leverage substantially exceed those of banks. The standard deviation of the empirical Bayes fixed effects is 3.4 times as large as that of banks, confirming the results from the simple cuts of the data. Overall, we find that the differences in capitalizing and leverage between shadow banks are substantially larger than differences in leverage and capitalization between banks. This fact is striking because shadow banks' business models are substantially more homogenous than those of banks. Differences across shadow banks capitalization are reminiscent of large leverage differences across non-financial firms, even within narrowly defined industries (see Lemmon et al. 2008).

\section{C Fact 3: Shadow Bank and Bank Debt Structure}

Bank debt has several distinctive features. It is primarily short term, and the lenders (depositors) are dispersed. A large portion of the debt is also insured by the FDIC. The short term and dispersed 
nature of debt, combined with high leverage, makes banks potentially prone to runs, i.e. fragile. Here, we examine which features of debt are present in shadow banks, and are thus independent of their ability to funds themselves with deposits.

Almost $100 \%$ of shadow bank debt is short-term compared to about $85 \%$ for banks. ${ }^{13}$ Short-term debt therefore plays an even more important role in the debt structure of shadow banks compared to banks. Figure 6 illustrates this point, and shows the virtual absence of long term debt funding across shadow banks. In contrast, there is more dispersion in how much reliance banks have on short-term debt funding. Table 6 illustrates this more formally by estimating the following specification:

$$
S D_{i, t}=\alpha+\beta_{1} \text { ShadowBank }_{i}+X_{\mathrm{i}, \mathrm{t}}^{\prime} \Gamma+\mu_{t}+\epsilon_{i, t}
$$

where $S D_{i, t}$ is the ratio of short-term debt to all debt of institution $i$ at time $t$. The key variable of interest is the shadow bank indicator, ShadowBank $k_{i}$, that takes the value of one if a lender is shadow bank and is zero otherwise. $X_{i, t}$ contains the same institution and local economic controls as other specifications. $\mu_{t}$ is the time fixed effect (year-quarter) which accounts for any time specific shocks that may impact capitalization ratios of all lenders. We estimate this specification across four different bank samples: the sample of all banks, OTD I, OTD II, and synthetic banks.

The results confirm the observation from summary statistics. The share of short term debt funding in shadow banks' is larger than that of banks, by at least 9-12 pp on average across bank comparison groups. This observation does not imply the maturity of shadow bank debt is shorter than that of banks. It is possible that the maturity banks' short term debt is much shorter than that of shadow banks. Instead, the results point to the absence of long-term debt funding for shadow banks. Overall, this evidence indicates that shadow banks appear to be even more reliant on shortterm debt than banks. Since shadow banks originate long maturity mortgages using short-term debt funding, they engage in liquidity and maturity transformation like banks.

The structure of shadow bank short-term debt differs significantly from that of bank debt on three dimensions. The first is obvious: bank debt is partially insured and shadow bank debt is uninsured. Insured deposits are a substantial fraction of that funding: on average they account for about two thirds of all short-term debt of banks and more than $60 \%$ of all bank debt. In contrast, shadow bank debt is uninsured by definition: shadow banks cannot raise deposits, insured or otherwise.

Second, bank debt is dispersed, and shadow bank is concentrated. Deposits-dispersed debtrepresent about $95 \%$ of short-term debt funding of banks. Shadow banks could also finance themselves with dispersed short-term debt, for example, through commercial paper. Instead, they use credit lines provided by on average by 3.6 lenders (Table 2, panel b). Lender concentration is

\footnotetext{
${ }^{13}$ Total debt excludes all trade-related liabilities, such as account payable and tax liabilities. Specifically, total debt includes debt facilities, commercial papers, mortgage debt, advanced federal home loans, and trusted preferred securities for shadow banks and it includes total deposits (for banks), repo, and an item called other borrowed money in the call report (such as FHLB advances or commercial papers).
} 
not an artifact of our shadow banks being small—recall that our sample is biased towards larger shadow banks, which on average originate about two billion dollars of loans per year. Appendix A4 shows the distribution of the number of lenders across shadow banks; even the $75^{\text {th }}$ percentile bank has only 5 lenders, and very few have more than 10 lenders.

The last differences is in the type of lenders providing loans. The main provider of shadow bank short term funding are large banks. Relative to dispersed depositors, concentrated bank lenders are likely more informed. Therefore, while banks and shadow banks fund themselves predominantly with short-term debt, the structure of shadow-bank debt fundamentally differs in three important aspects from those of banks: (i) shadow bank debt is uninsured and (ii) shadow bank debt is highly concentrated among few creditors (iii) shadow bank lenders are banks.

\section{Section 5: Uninsured Leverage Declines with Size}

We begin this section by showing that shadow bank leverage increases substantially with size. As one would expect, this relationship is not present for banks, given small differences in bank leverage. This result implies small bank capitalization deviates from comparable shadow banks' capitalization substantially more than large bank capitalization does. In the second part of this section we provide evidence that the size leverage relationship is not specific to shadow banks, but is masked by insured deposit funding of banks. We find similar patterns for banks, once we focus on the uninsured part of their debt funding.

\section{A Fact 4: Capitalization Declines with Size for Shadow Banks (and not Banks)}

We begin by showing simple cuts of raw data: we compute the average capitalization across size bins in Figure 7. Two main observations emerge. First, shadow bank capitalization declines substantially with leverage. The smallest shadow banks' average capitalization ranges between approximately $46 \%$ and $58 \%$. The largest shadow banks ranges between $15 \%$ and $20 \%$. This result is robust across different measures of capitalization and size. Capitalization measured by Tier 1 capital also substantially declines with size. The upper bound of Tier 1 capital declines from 57\% to $29 \%$ from the smallest shadow bank to the largest shadow banks; this decline is $56 \%$ to $20 \%$ for the lower bound of Tier 1 capital (Appendix A5). We obtain similar results for equity to asset ratio when use logarithm of assets as the size measure (see Appendix A7). This is not surprising since our two size measures, loan volume and assets, are highly correlated (see Appendix A6).

The second observation is that the difference in capitalization between shadow banks and banks declines with size. For our baseline comparison group (Figure 7, Panel a), the smallest shadow banks' equity to asset ratios is $35 \mathrm{pp}$ to $47 \mathrm{pp}$ higher than the capitalization of banks of equal size, which ranges between $10.8 \%$ and $11 \%$. In other words, the capitalization of the smallest banks is approximately 4.2 to 5.4 times as large as that of similar sized banks. The capitalization of the largest shadow banks, on the other hand, is substantially closer to the capitalization of banks of similar size, exceeding their capitalization by $32 \%$ to $73 \%$. This difference is still sizeable, but it is substantially smaller than that of small banks. The fact that the difference between the capitalizations of shadow banks and similarly sized banks declines with size is robust across 
different bank comparison groups (Figure 7, Panels a-d), adjusting for risk weights in measuring capital (Appendix A5) and different measures of size (Appendix A7 and A8). The only differences arise when we compare the largest shadow banks to the largest banks across specifications. In a few subsamples, and if we assign shadow banks the highest risk weights, then the capitalization of largest shadow banks in the largest subsamples is indistinguishable from large banks. Overall, these results suggest that small banks have substantially less capital than small shadow banks, and capitalization of large banks' is much closer to that of large shadow banks.

In the rest of this subsection, we ensure that this result is robust. We estimate the following specification for the equity to asset ratio:

$$
\text { Ratio }_{i, t}=\alpha+\beta_{1} \text { ShadowBank }_{i}+\beta_{2} \text { ShadowBank }_{i} \times \text { Size }_{i, t}+X_{\mathrm{i}, \mathrm{t}}^{\prime} \Gamma+\mu_{t}+\epsilon_{i, t}
$$

The key variables of interest are the shadow bank indicator, ShadowBank $k_{i}$, and its interaction with size. ShadowBank $k_{i} \times \operatorname{Siz}_{i, t} . \mu_{t}$ is the time fixed effect (year-quarter), which absorbs time series variation in equity to asset ratio. As before, $X_{i, t}$ contains institution and local economic controls, including size, asset growth, the share of refinanced loans out of total loan origination portfolio, the share of government-insured loans out of total loan origination portfolio, the institution's dispersion (diversification) of residential lending activity, and the logarithm of the weighted average of income per capita in states of operation.

The estimated shadow bank dummy for capitalization is positive, while its interaction terms with size is negative across specifications and different bank comparison subsamples (Table 7). A two standard deviation change in size decreases shadow bank capitalization relative to corresponding banks by approximately 12-13pp across specifications. This result is robust across bank comparison groups (columns 2-4 of Table 7), and to different measures of capital and size (Appendix A9-A11). Overall, the results confirm that shadow bank capitalization decreases substantially with size, and that small bank capitalization is substantially smaller than that of comparable shadow banks; the capitalization of the large banks, on average, is only a little lower than that of shadow banks of comparable size.

\section{B Fact 5: Uninsured Leverage, Debt Funding Cost, and Size}

\section{Intermediaries' Uninsured Leverage Increases in Size}

We next try to understand why shadow bank capitalization is decreasing in size, but this phenomenon is absent from banks. There are broadly two alternatives to explain this result. The first is that the relationship would have been there for banks, if it were not for deposit subsidies and other regulations. The alternative is that this is a shadow bank specific phenomenon. Our results suggest the former. We find that banks' uninsured debt financing, which we term "uninsured leverage," increases in size. Since all shadow bank debt is uninsured, this implies that the same phenomenon, an increase in uninsured leverage, is present in both banks and shadow banks. We then show that the average cost of uninsured (but not insured) debt financing declines 
with size for both banks and shadow banks. These results are consistent with the notion that the choice of uninsured leverage is driven by similar factors for banks and shadow banks.

We focus on uninsured bank debt for two reasons. The first is that all shadow bank debt is uninsured, i.e. it bears default risk. Insured deposits-bear no default risk, because insured depositors are insured by the FDIC. Only the uninsured portion of debt-uninsured deposits, foreign deposits, repos, other borrowed money, and subordinated debt—is similar to debt taken up by shadow banks and other firms in the economy. The second reason is theoretical. A substantial share of theories of optimal capital structure require that debt-holders internalize some cost of default, at least off equilibrium. For example, debt holders only have incentives to monitor if they suffer default costs in the absence of monitoring. Similarly, trade-off theories of capital structure require debt-holders to internalize the cost of default. Our previous results show that the overall share of bank debt financing does not change much with size.

To compare the leverage decisions of banks and shadow banks as they relate to uninsured funding, we define "uninsured leverage" $L^{u}$ for banks and shadow banks. Consistent with the banking literature, the main object of our analysis heretofore has been bank capitalization, defined as $C_{i}=$ $\frac{E_{i}}{A_{i}}$, in which $E_{i}$ is the equity and $A_{i}$ are assets of financial institution $i$. The leverage of intermediary $i$ is simply $L_{i}=1-C_{i}$. Therefore, our previous result that capitalization increases with shadow bank size can equivalently be stated as leverage increases with size for shadow banks, but not for banks.

We define "uninsured leverage" of a financial intermediary $i$ as $L_{i}^{u}=\frac{D_{i}^{u}}{A_{i}}$, in which $D_{i}^{u}$ represents the uninsured debt of intermediary $i$ (uninsured deposits, foreign deposits, repos, other borrowed money, and subordinated debt). Uninsured leverage then measures the share of uninsured debt in the capital structure of a financial intermediary. We define the insured leverage for banks as the ratio of insured deposits to bank assets. Since shadow banks have no insured deposits, their uninsured leverage mechanically equals the share of their debt in the capital structure. For banks, the wedge between uninsured leverage and overall leverage is driven by insured deposits.

We illustrate how uninsured leverage evolves with size of banks and shadow banks in Figure 9. As we observe uninsured shadow bank leverage increases from $54 \%$ to $80 \%$, or about $26 \mathrm{pp}$ for shadow banks over the same size range. Uninsured leverage increases from $23 \%$ to $40 \%$, or about $17 \mathrm{pp}$, across the distribution of size in the sample of all banks. We also find a significant increase in uninsured bank leverage across other bank comparison samples (Panels b-d). Larger financial institutions, both banks and shadow banks, finance themselves with more uninsured leverage. This pattern is robust despite the large differences between banks and shadow banks in the type of uninsured debt they use.

How does uninsured leverage of banks increase with size while overall leverage remains fairly stable? Since the overall amount of leverage stays fixed, it implies that the share of insured deposits to other debt funding (uninsured deposits) declines with size. Figure 8 confirms that intuition. 
Large banks rely much less on insured funding than small banks. This change in the composition of debt obscures the large increase in uninsured bank leverage with size.

Since banks' business models can differ significantly, one may be concerned that that larger banks rely more on uninsured debt funding because they engage in fundamentally different activities than banks. A priori, this is not likely, since we observe the same pattern for shadow banks, which are much more homogenous. Nevertheless, we explore this alternative using the following regression specification:

$$
L_{i, t}^{u}=\alpha+\beta \operatorname{Size}_{i, t}+X_{i, t}^{\prime} \Gamma+\mu_{t}+\epsilon_{i, t}
$$

$L_{i, t}^{u}$ is the uninsured leverage of intermediary $i$ in year $t$. Size $e_{i, t}$ is our independent variable of interest. $X_{i, t}$ is a vector of institution and local economic controls, which we have used in our prior specifications. We include the year fixed effect in our regressions and estimate this specification separately for banks and shadow banks.

The results presented in Table 8 confirm the insights from Figure 9. Uninsured leverage substantially increases with size for both banks and shadow banks. A two standard deviation increase in size is correlated with an increase in uninsured leverage between 4.2-8.6pp for banks and about 13-20pp for shadow banks. Within the sample of all banks and shadow banks, this implies a relative increase by about $30 \%$ in the uninsured leverage (relative to their respective means). The results suggest that the (privately) optimal capital structure of financial intermediaries, both banks and shadow banks, tilts towards more (uninsured) debt as size of intermediaries increases. Again, this finding is robust to alternative definition of size (see Appendix A12).

\section{Intermediaries' Uninsured Debt Rates Decline with Size}

We next show that uninsured debt interest rates declines with size for banks and shadow banks. This evidence bolsters the idea that the same underlying forces drives the relationship between size and uninsured leverage changes for banks and shadow banks. Figure 10 shows that the average uninsured debt rates decline with size for both banks and shadow banks. ${ }^{14}$ The decline is significant: the interest rates paid by the largest shadow banks are approximately 300bp lower than that of the smallest shadow banks; for banks, the difference is on the order of 100bp.

One concern is that bank rates, especially on uninsured deposits, decline with size because larger banks provide more services, which are bundled with deposits. Depositors would pay for these services implicitly through lower deposit rates. Since we observe the same decline in rates for shadow banks this is less likely. While larger shadow banks may offer a better service to their borrowers, it is unclear which services they would offer to the providers of their warehouse credit lines. Nevertheless, we address this concern head-on in Figure 10 by examining rates on insured

\footnotetext{
14 The cost of uninsured debt is calculated using an intermediary's total interest expense on uninsured debt in year $\mathrm{t}$ divided by its total uninsured debt outstanding in year $t$.
} 
deposits, which should also capture service provision (Egan et al. 2017). We find no market decline in insured rates; if anything, the cost of insured deposits is increasing in size across a significant range. To probe this idea further, we compute the within bank difference in uninsured and insured debt rates. The idea is that if a bank provides better services, which are priced in deposit rates, it does so for insured and uninsured deposits. We plot how the difference in uninsured an insured debt rates changes with bank size in panel (c) of Figure 9. Consistent with prior evidence, uninsured debt rates decline with bank size, even relative to insured deposit rates. Therefore, it is unlikely that the decline in bank cost of uninsured funding arises because larger banks provide more services. Instead, as we discuss in Section 6, these results are more consistent with the idea that uninsured rates price how various frictions change with intermediary size.

We also formally test the relationship between rates on uninsured debt and intermediary size using the following specification, which we estimate separately for banks and shadow banks:

$$
\text { Rate }_{i, t}^{u}=\alpha+\beta \text { Size }_{i, t}+X_{i, t}^{\prime} \Gamma+\mu_{t}+\epsilon_{i, t}
$$

Rate $_{i, t}^{u}$ is the average interest rate an intermediary $i$ pays on its uninsured debt in year $t$. Size $e_{i, t}$ is our independent variable of interest, which is measured by the logarithm of mortgage origination volume. $X_{i, t}$ is a vector of institution and local economic controls. We include the year fixed effect in our regressions and cluster the standard errors by shadow banks. For banks, we also estimate a separate specification, in which the dependent variable is instead the difference between insured and uninsured rates a bank pays Rate $_{i, t}^{u}-$ Rate $_{i, t}^{i}$.

The results in Table 9 confirm that the average rate on uninsured debt declines significantly with size for both banks and shadow banks. A two standard deviation increase in size is correlated with a 200bp decline in uninsured debt rate for shadow banks and about 46bp decline for banks. Moreover, the within-bank difference between uninsured debt and insured deposit rates declines by about $60 \mathrm{bp}$, suggesting that the majority of the effect is driven by the decline in rates on uninsured debt. In other words, mirroring the results from Figure 9, large banks and shadow banks pay substantially smaller rates on their debt, even after conditioning on their characteristics, such as portfolio diversification, and despite having higher uninsured leverage. We find broadly similar evidence with alternative definition of size (see Appendix A13). To recap, larger financial intermediaries have higher uninsured leverage, and pay lower average rates on their uninsured debt. This is true both for banks, and for shadow banks. These results are consistent with the notion that choice of uninsured leverage may be driven by similar factors for banks and shadow banks.

\section{C External Validity: Pre-deposit-insurance banks in U.S and Germany}

In this section we show that the capital structure of shadow banks in the post 2011 U.S. resembles that of pre-deposit-insurance banks in the U.S. and Germany: they are better capitalized than modern banks, with substantial heterogeneity in leverage across institutions, funded predominantly with short term debt, and leverage increases substantially with size. The resemblance to pre-deposit insurance banks suggest our results are unlikely due to factors, which are specific to shadow banks' 
business model, the post-crisis period during which we examine them, or the specifics of the modern U.S. in which they operate.

Our analysis is based on the idea that shadow banks and banks engage in similar activities, and that the first order difference in the capital structure between these institutions is banks' ability to obtain insured deposits, and the regulatory framework aimed at banks. Then the deviations we observe between shadow banks and banks are due to differences in subsidies and regulations. We provide extensive evidence that supports this interpretation of our facts. On the other hand, we our sample is limited to the post 2011 period shadow banks in the U.S. One concern is that the differences we observe between shadow banks and banks may be limited to the regulatory and economic environment in this period. We next provide further evidence that the capital structure of our shadow banks mimics that of banks without deposit insurance. Since there are no modern U.S. banks without deposit insurance, we look into the pre-deposit insurance period both in the U.S. and Germany.

Specifically, Aldunate et al. (2019) collect data on more than 6,000 U.S. banks in in 1928, prior to the establishment of the FDIC. Using their data, we plot the leverage of these banks as a function of bank size in Appendix B1. ${ }^{15}$ Three facts stand out. First, these banks are substantially better capitalized than modern banks, with average equity to assets of about $18 \mathrm{pp}$, which is close to the capitalization of shadow banks in our sample. Second, there are substantial differences in capitalization across banks before deposit insurance, bolstering our claim that homogeneity in capital structure of modern banks arises as a result of regulation and subsidies, rather than a fundamental intermediation activity. Last, the leverage of pre-FDIC banks strongly increased with bank size. In other words, the pre-FDIC banks display the same (uninsured) leverage and size relationship we document in modern U.S. shadow banks. Given that the funding structure of predeposit insurance banks is similar to modern shadow banks, it is unlikely that shadow banks' capital structure arose as a response to post-financial-crisis circumstances. We observe the same patterns in the data from German banks in 1931 collected by Blickle et al. (2019), which we present in Appendix B2. ${ }^{16}$

To summarize, the capital structure of shadow banks in the U.S. post 2011 resembles that of predeposit-insurance banks in the U.S. and Germany: they are better capitalized than modern banks, with substantial heterogeneity in leverage across institutions, funded predominantly with short term debt, and leverage increases substantially with size. The resemblance to pre-deposit insurance banks suggest our results are unlikely due to factors, which are specific to shadow banks' business model such as originating mortgages - residential mortgages were not the primary activity of the pre-FDIC banks. It also rejects the alternative that our results are specific to the post-crisis period during which we examine them, or the specifics of the modern U.S. in which they operate. Instead,

\footnotetext{
${ }^{15}$ We thank Aldunate et al. (2019) for generously sharing their data.

${ }^{16}$ We thank Marcus Brunnermeier, our discussant at the NBER Corporate Finance Program Meeting, for providing these facts.
} 
it is much more likely that the differences in capital structures of modern shadow banks and banks are due to differences in subsidies and regulations.

\section{Discussion: Capital Structure of Intermediaries, and Implications for Policy}

We started this paper with positing two alterative views of what drives banks' choice of capital structure. One view is that bank capital structure primarily arises from contracting between equity holders and creditors to resolve fundamental frictions, which arise in financial intermediation. These frictions can be specific to intermediation, such as risk sharing of liquidity shocks, or more general, such as informational frictions, or bankruptcy costs. The alternative view is that banks' capital structure is set up to extract subsidies available to intermediaries with a bank charter. Principally, banks have the ability to raise cheap debt, insured deposits, but are subject to capital requirements, which reduces the flexibility of funding choices. We evaluate these views by studying capital structure decisions of shadow banks: intermediaries that provide banking services but are not funded by deposits. We use these intermediaries as a benchmark to evaluate capital structure decisions for banks in the absence of deposit financing and capital requirements. Our results suggest that it is important to distinguish the marginal and infra-marginal determinants of bank capital structure decisions. We conclude this section by discussing broad implications for intermediary regulation.

Before proceeding with the discussion, we want to mention some caveats to our analysis. The first is that shadow banks, which we analyze, are only a good benchmark when considering the loan provision function of banks. We do not speak to banks' function as providers of savings vehicles backed by banks' portfolios, ${ }^{17}$ or their function in the payments system. As we discuss below, we do not think this limitation is particularity problematic for making inferences on capital structure decisions in light of the evidence we observe. Second, shadow banks are not direct recipients of subsidies nor do they face capital regulation. But bank subsidies and regulation could indirectly shape shadow banks' capital structure in equilibrium. This could occur either through competition with banks, or through interactions of shadow banks with banks in the warehouse funding market, in ways similar to non-financial firms. Therefore, it is more appropriate to consider the capital structure of shadow banks as a benchmark of banks' capital structure in a world without direct subsidies to deposits and without capital regulation. With these caveats out of the way, we first turn to some first order implications of our facts.

\section{A Bank Capitalization at the Margin}

Our first two results suggest that banks' level of capitalization is pinned down by deposit subsidies and capital regulation at the margin. First, shadow banks' have much higher capitalization than shadow banks. Second, there are large differences in capitalization across shadow banks, while the capitalization of banks is relatively homogenous. Larger differences among shadow banks arise despite their more homogenous business models and in the types of loans they make. There are

\footnotetext{
${ }^{17}$ Mutual funds may be a better benchmark for this function.
} 
large differences in banks' portfolios, ${ }^{18}$ but their leverage is highly homogenous; the assets of shadow banks, on the other hand, are quite homogenous, but are funded with very different types of leverage. If leverage is pinned down by the desire to minimize frictions that arise in financial intermediation, then we would expect more homogeneity in the capital structures of shadow banks, rather than less.

The level and dispersion of shadow bank capitalization relative to bank capitalization suggests that a substantial proportion of banks take advantage of the deposit subsidy and this drives their capital structure choice. Moreover, the fact that all banks have similar leverage suggests that their leverage ratios are likely pinned down by capital requirements. In other words, the most parsimonious model that explains why bank capitalization is about half of shadow banks, and, at the same time why capitalization across banks is so homogenous is the following: banks borrow as much as they can subject to capital requirements, because they have access to subsidized debt funding. The differences in their capital structure arise from buffer stock considerations (e.g., as in Corbae and D'Erasmo 2018).

These results also imply that very if high leverage were fundamental to the provision of lending, we should have found shadow banks' leverage to be as high as those of deposit-taking banks. Instead, the average capitalization of modern shadow banks (25\%) is in line with substantially higher equity capitalization of some banks prior to deposit insurance (see Admati and Hellwig 2014, Hanson et al. 2015, Aldunate et al. 2019, Blickle et al. 2019). Second, our results reject the argument that homogeneity in leverage across banks is driven by value creating activities, which arise from the optimal provision of intermediary services on the asset side.

\section{B Intermediary Capital Structure in the Absence of Subsidies and Regulation}

Given the importance of subsidies in determining banks' capital structure, one might conclude that the only objective in banks' capital structure decisions is to maximize subsidies. In other words, banks' capital structure differs from that of non-financial firms only because of subsides. Our results suggest this extreme interpretation is not correct for two broad reasons. First, shadow bank leverage substantially exceeds that of non-financials, suggesting that intermediary incentives to fund with (short term) debt are high, even in the absence of subsidies. Because of the extent of the subsidies, however, these incentives are infra-marginal for banks, especially small ones. Second, examining the structure of shadow bank debt, rather than just the level of leverage, we find several commonalities with banks. These results suggest that the structure of debt is at least partly chosen to address underlying, fundamental factors and frictions related to financial intermediation.

It is difficult to pin down a specific friction, which is responsible for the substantially higher leverage of financial intermediaries relative to non-financial firms. These frictions can be specific to banks, such as risk sharing of liquidity shocks in Diamond (1984), or more generic corporate finance frictions such as hidden action, hidden information, liquidation costs, or incomplete

\footnotetext{
${ }^{18}$ Banks differ among others in the share of securities versus loans they hold on the balance sheet, the types of loans they hold, and the securities they hold.
} 
contracting (e.g., Townsend 1979; Bolton and Scharfstein 1990; Holmstrom and Tirole 1997; Hart and Moore 1998; DeMarzo and Fishman 2007). Viewed through the lenses of corporate finance models the high leverage of financial intermediaries would imply, on average, less risky cashflows or less intense underlying frictions of financial intermediaries relative to non-financial firms. High leverage of financial intermediaries could be also a byproduct of liquidity production (e.g., see DeAngelo and Stulz 2015). As we noted in introduction section, such arguments could apply to shadow banks we focus on if one would consider the short-term warehouse credit line debt as a relatively liquid form of investment from the banks' perspective.

The relationship between debt interest rates and intermediary size can help narrow the scope of potential explanations behind this effect. Because uninsured leverage of intermediaries increases in size, then either the benefits of uninsured leverage increase with size, or the costs of uninsured debt financing decline. The declining rates certainly suggest that lenders perceive larger intermediaries, both banks and shadow banks to be safer. One possible driver of this effect could be lower cashflow risk due to risk diversification benefits that increase with size as in Diamond (1984), although measures along these two dimensions do not explain the entirety of the size effect. Viewed through the lens of trade-off models and capital structure models with frictions, our results are also consistent with higher bankruptcy (liquidation) costs, more intense agency frictions or higher monitoring costs for smaller financial intermediaries relative to larger ones. Finally, the heterogeneity across capital structures of shadow banks engaged in similar activities is also consistent with models where leverage is dependent on the history of the firm's realized cashflows (e.g., DeMarzo and Sannikov 2006; DeMarzo and Fishman 2007; Bias et al. 2007; Bolton et al. 2011; He and Krishnamurthy 2011; Brunnermeier and Sannikov 2014; DeMarzo and He 2016; Admati et al. 2018).

\section{C Structure of Debt, Bank Size, and Uninsured Leverage}

As we documented above, the overall level of capitalization (leverage) for banks departs significantly from that of shadow banks. There are at least two features of shadow bank capital structure, which are mirrored in shadow banks. Like banks, shadow banks finance themselves primarily with short-term debt and originate long-term loans. In other words, banks engage in maturity transformation. Second, uninsured leverage is increasing with size, and the average cost of uninsured debt is decreasing in size for both banks and shadow banks. If shadow banks provide a window into bank funding without subsidized deposits, then these results suggest that short term debt is fundamental to financial intermediation. In other words, deposit subsidies do not seem to be the main driver of financial intermediary debt maturity.

Short maturity of debt can either arise because investors who face potential liquidity shocks demand such instruments, and are therefore willing to pay a premium for them (Diamond and Dybvig 1983; Allen and Gale 2007; Goldstein and Pauzner 2005; Gorton and Pennacchi 1990; Holmström and Tirole 1998). While some of these theories are aimed at rationalizing demand by depositors, it is possible that the suppliers of credit lines to shadow banks have such (derived) preferences on their own. Alternatively, short term run-prone debt serves a monitoring function as 
in Diamond (1984), Calomiris and Kahn (1991), Diamond and Rajan, (2001). The incentives to monitor are generated through a sequential service constraint. Finally, contractual externalities among multiple creditors can also result in short-term debt maturity structures (e.g., Brunnermeier and Oehmke 2013).

Despite these commonalities, there are important differences in the structure of short term debt as well. While debtholders funding banks are dispersed (depositors), those funding shadow banks are concentrated. Thus, our results suggest that it is important that intermediary debt is short term, and that uninsured debt increases with bank size. On the other hand, the fact that debt is held by dispersed investors does not seem to be a robust feature of intermediary capital structure.

Both sets of theories have their shortcomings relative to the data. While demand for liquidity may be able to explain the preponderance of short-term funding of financial intermediaries, it has a difficult time explaining the relationship between size and uninsured leverage, unless paired with other factors, such as size-related risk diversification benefits or changes in bankruptcy costs. The monitoring models of Calomiris and Kahn (1991) and Diamond and Rajan, (2001) create incentives to monitor through run-prone debt. Since shadow bank debt is highly concentrated, and provided by (potentially) informed lenders, the broad message of monitoring resonates. The idea, that fragility related to highly dispersed debt holdings is an essential component of this monitoring, however, does not.

\section{D Regulatory Implications}

Capital requirements, FDIC assessment rates, as well as other forms of regulation are frequently stricter for large banks. Perhaps the most surprising result of our paper is that the banks' deviation in capital structure choices from those of shadow banks are the largest for small banks. Small banks are substantially less capitalized than shadow banks of corresponding size, and rely substantially less on uninsured debt funding. In other words, insured deposits present a substantially larger part of funding for small banks than large banks. Moreover, deposit funding substitutes equity funding for such banks, especially relative to shadow banks. Our results suggest that it is the small banks, which benefit most from the insured deposit subsidy.

If small banks are the primary recipients of deposit subsidies, then size-based regulations have to be more closely targeted to the frictions they are supposed to resolve. In other words, if regulations are in place to prevent spillovers from the failure of banks, then regulations should be stricter for large, and especially systemically important, banks. If, on the other hand, regulation and implicit taxes on funding are in place to offset deposit subsidies, then our results suggest that these should be stricter for smaller banks.

Second, as shadow bank activities demonstrate, lower leverage of financial intermediaries is not necessarily an impediment to lending. Therefore, increasing capital requirements may not be very costly from the perspective of lending. This intuition is consistent with significant recent expansion of shadow bank lending (see Buchak et al. 2018) and with relatively modest effects of higher capital requirements on aggregate lending volume (Buchak et al. 2019). However, since banks 
provide bulk of the funding to shadow banks through warehouse lines of credit, there may be an equilibrium funding response to changes in bank capital requirements that one need to consider.

\section{E Bank Fragility and Financial Stability}

One issue, which remains unclear is whether the capital structure of shadow banks, especially large ones, are more or less fragile than that of banks. On the one hand, large shadow banks have similar capital ratios to banks, but have a much higher ratio of potentially run-prone uninsured debt. This might suggest that capital structure of large shadow banks is more fragile than that of banks of similar size. However, the debt holdings of shadow banks are very concentrated and held by a few potentially informed lenders (large banks). In the canonical Diamond and Dybvig (1983) setup fragility of deposit funded banks arises to a large degree because (uninformed) individual small depositors do not internalize the impact of their withdrawals on banks survival. Viewed from this lens, one could argue that capital structure of large shadow banks is less fragile. Resolving whether such considerations shape the capital structure of intermediaries remains an area of future research.

Relatedly, one could also consider the possible spillovers across institutions that can arise from direct contractual funding links between banks and shadow banks or can occur indirectly through price and liquidity effects (Adrian and Brunnermeier 2016). Understanding the role that such effects may have on capital structure of intermediaries is a fruitful avenue for future research. 


\section{References}

Admati, A, R., P. M. DeMarzo, M. F. Hellwig, and P. Pfleiderer, 2013, Fallacies, Irrelevant Facts, and Myths in the Discussion of Capital Regulation: Why Bank Equity Is Not Socially Expensive, Working Paper, Stanford University.

Admati, A. R. and M. F. Hellwig, 2014, "Bankers New Clothes: What's wrong with Banking and what to do about it?" Adrian, T., and A. B. Ashcraft, 2016, Shadow Banking: A Review of the Literature. In Banking Crises, pp. 282-315. Palgrave Macmillan UK.

Admati, A, R., P. M. DeMarzo, M. F. Hellwig, and P. Pfleiderer, 2018, The Leverage Rachet Effect, Journal of Finance 73, 145-198.

Adrian, T., and M. K. Brunnermeier, 2017, CoVaR, American Economic Review 106, 1705-1741.

Adrian, T., and H. S. Shin, 2010, Liquidity and Leverage, Journal of Financial Intermediation 19, 418-437.

Aldunate, F., D. Jenter, A. Korteweg, and P. Koudijs, 2019, Double Liability, Working Paper.

Allen, F., and D. Gale, 2007, Understanding Financial Crises, Oxford: Oxford University Press.

Berndt, A., D. Duffie, and Y. Zhu, 2018, The Decline of Too Big to Fail, Working Paper.

Begenau, J., and T. Landvoigt, 2018, Financial Regulation in a Quantitative Model of the Modern Banking System, Working Paper.

Biais, B., T. Mariotti, G. Plantin, and J.-Ch. Rochet, 2007, Dynamic Security Design: Convergence to Continuous Time and Asset Pricing Implications, Review of Economic Studies 74, 345-390.

Blickle, K., M. Brunnermeier, and S. Luck, 2019, Micro-Evidence from a System Wide Financial Meltdown: The German Crisis of 1931, working paper.

Bolton, P., and D. Scharfstein, 1990, A Theory of the Predation Based on Agency Problems in Financial Contracting, American Economic Review 80, 93-106.

Bolton, P., H. Chen, and N. Wang, 2011, A Unified Theory of Tobin's q, Corporate Investment, Financing, and Risk Management, Journal of Finance 66, 1545-1578.

Brunnermeier, M. K., and Y. Sannikov, 2014, A Macroeconomic Model with a Financial Sector, American Economic Review 104, 379-421.

Brunnermeier, M. K, and M. Oehmke, 2013, The Maturity Rat Race, Journal of Finance 68, 483521.

Buchak, G., G. Matvos. T. Piskorski, and A. Seru, 2018, Fintech, Regulatory Arbitrage and the Rise of Shadow Banks, Journal of Financial Economics 130, 453-483.

Buchak, G., G. Matvos. T. Piskorski, and A. Seru, 2019, Beyond the Balance Sheet Model of Banking: Implications for Bank Regulation and Monetary Policy, Working Paper.

Calomiris, C., and C. M. Kahn, 1991, The Role of Demandable Debt in Structuring Optimal Banking Arrangements, American Economic Review 81, 497-513.

Calomiris, C., and M. Jaremski, 2016, Deposit Insurance: Theories and Facts, Annual Review of Financial Economics 8, 97-120. 
Calomiris, C., and M. Jaremski, 2019, Stealing Deposits: Deposit Insurance, Risk-Taking, and the Removal of Market Discipline in Early 20th-Century Banks, Journal of Finance 74, 711-754.

Corbae, D., and P. D’Erasmo, 2019, Capital Requirements in a Quantitative Model of Banking Industry Dynamics, Working Paper.

DeAngelo, H., and R. M. Stulz. 2013, Why Hgh Leverage Is Optimal for Banks, National Bureau of Economic Research Working Paper 19139.

DeMarzo, P. M., and M. J. Fishman, 2007, Optimal Long-Term Financial Contracting, Review of Financial Studies 20, 2079-2128.

DeMarzo, P. M., and Y. Sannikov, 2006, Optimal Security Design and Dynamic Capital Structure in a Continuous-Time Agency Model, Journal of Finance 61, 2681-2724.

DeMarzo, P. M., and Z. He, 2016, Leverage Dynamics without Commitment, Working Paper.

DeMarzo, P. M., 2019, Collateral and Commitment, Journal of Finance, 74, 1587-1619.

DeAngelo, H., and R. M. Stulz, 2015, Liquid-claim Production, Risk Management, and Bank Capital Structure: Why High Leverage is Optimal for Banks, Journal of Financial Economics 116, 219-236.

Deng, T., G. Gorton and B. Holmstrom, 2017, Information Sensitivity of a Security, Working Paper.

Diamond, D. W., and P. H. Dybvig, 1983, Bank Runs, Deposit Insurance, and Liquidity, Journal of Political Economy 91, 401-419.

Diamond, D. W, 1991, Debt Maturity Structure and Liquidity Risk, Quarterly Journal of Economics 106, 709-737

Diamond, D. W., and R. G. Rajan, 2000, A Theory of Bank Capital, Journal of Finance 55, 24312465.

Diamond, D. W., and R. G. Rajan, 2001, Liquidity Risk, Liquidity Creation, and Financial Fragility: A Theory of Banking, Journal of Political Economy 109, 287-327.

Dwyer, G. P., 1981, The Effects of the Banking Acts of 1933 and 1935 on Capital Investment in Commercial Banking, Journal of Money, Credit and Banking 13, 192-204.

Egan, M., A. Hortascu, and G. Matvos, 2017, Deposit Competition and Financial Fragility: Evidence from the US Banking Sector, American Economic Review 107, 169-216.

Egan, M., S. Lewellen, and A. Sunderam, 2019, The Cross Section of Bank Value, Working Paper. Gennaioli, N., A. Shleifer, and R. W. Vishny, 2013, A Model of Shadow Banking, Journal of Finance 68, 1331-1363.

Goldstein, I. and A. Pauzner, 2005, Demand-Deposit Contracts and Probability of Bank Runs, Journal of Finance, 60, 1293-1327

Gorton, G., and G. Pennacchi. 1990, Financial Intermediaries and Liquidity Creation, Journal of Finance 45, 49-71. 
Hanson, S. G., A. Shleifer, J. C. Stein, and R. W. Vishny, 2015, Banks as Patient Fixed-Income Investors, Journal of Financial Economics, 449-469.

Hart, O., and J. Moore, 1998, Default and Renegotiation: A Dynamic Model of Debt, Quarterly Journal of Economics 113, 1-41.

He, Z., and A. Krishnamurthy, 2011, A Model of Capital and Crises, Review of Economic Studies 79, 735-777.

Holmström, B. and Jean. Tirole, 1997, Financial Intermediation, Loanable Funds, and the Real Sector, Quarterly Journal of Economics, 112, 663-691.

Irani, R.M., R. Iyer, R.R. Meisenzahl and J.L. Peydro, 2018. The Rise of Shadow Banking: Evidence from Capital Regulation, Working Paper.

Jensen, M., and W. H. Meckling, 1976, Theory of the Firm: Managerial Behavior, Agency Costs and Ownership Structure, Journal of Financial Economics 3, 305-360.

Jiang, E., 2019, Financing Competitors, Working Paper.

Keys, B. J., T. Mukherjee, A. Seru, and V. Vig, 2010, Did Securitization Lead to Lax Screening? Evidence from Subprime Loans, Quarterly Journal of Economics 125, 307-362.

Keys, B. J., T. Piskorski, A. Seru, and V. Vig, 2013, Mortgage Financing in the Housing Boom and Bust. In Housing and Financial Crisis, Edited by Edward L. Glaeser and Todd Sinai, 143-204, University of Chicago Press and NBER.

Leland, H., 1994, Corporate Debt Value, Bond Covenants, and Optimal Capital Structure, Journal of Finance 49, 1213-1252

Lemmon, M. L., Roberts, M. R., and J. F. Zender, 2008, Back to the Beginning: Persistence and the Cross-Section of Corporate Capital Structure, Journal of Finance 63, 1575-1608.

Pyle, D.,1984, Deregulation and Deposit Insurance Reform, 1984, Economic Review, Federal Reserve Bank of San Francisco, Spring Issue, 5-15.

Townsend, R. M., 1979, Optimal Contracts and Competitive Markets with Costly State Verification, Journal of Economic Theory 21, 265-293. 


\section{Table 1: Shadow Bank Call Reports - Asset and Income Composition}

This table reports the mean asset composition (panel a) and income statement (panel b) of shadow banks active in the US mortgage market in our sample ranging from 2011 Q1 to 2017 Q4. We restrict attention to mortgage companies that are required to file HMDA reports and originate mortgage loans. This restriction leaves us with 429 shadow banks that have a license in the two states that provided us data. Data Sources: Shadow banks' quarterly call report filings to state regulators.

Panel A: Asset composition as percentage of total assets

\begin{tabular}{lc}
\hline & Mean \\
\hline Cash & $11.66 \%$ \\
Receivable & $3.24 \%$ \\
Securities & $0.34 \%$ \\
Mortgages Held for Sale & $63.61 \%$ \\
Mortgages Held for Investment & $3.55 \%$ \\
Mortgage Servicing Rights & $7.56 \%$ \\
Real Estate Owned & $0.28 \%$ \\
Building and Properties & $2.00 \%$ \\
Good will and Intangible Assets & $0.33 \%$ \\
Derivatives & $1.43 \%$ \\
Technology Capital & $0.40 \%$ \\
\hline No. of Institutions & 429 \\
\hline \hline
\end{tabular}

Panel B: Income and expense composition as percentage of total income and expenses

\begin{tabular}{lc|lc}
\hline \hline Gross Income & Mean & Total Expenses & Mean \\
\hline Total Interest Income & $8.48 \%$ & Total Interest Expenses & $7.13 \%$ \\
Mortgages Held for Sale & $5.16 \%$ & Warehouse Interest Expense & $5.48 \%$ \\
Mortgages Held for Investment & $1.90 \%$ & MBS Prepayment Interest Shortfall & $0.10 \%$ \\
Securities & $0.10 \%$ & MSR Assets & $0.15 \%$ \\
Other Interest Income & $0.69 \%$ & Debt Issuance & $0.48 \%$ \\
Total Origination-Related Income & $17.89 \%$ & Other Interest Expense & $0.91 \%$ \\
Origination Fees & $11.25 \%$ & Total Personnel Expenses & $55.64 \%$ \\
Fees Received from Correspondents & $2.15 \%$ & Total Origination Compensation & $40.31 \%$ \\
Other Origination-Related Income & $3.22 \%$ & Total Servicing Compensation & $1.95 \%$ \\
Total Secondary Market Gains on Sale & $55.79 \%$ & Other Personnel & $6.77 \%$ \\
Mortgages Sold with Servicing Retained & $18.50 \%$ & Total Other Non-Interest Expenses & $27.36 \%$ \\
Capitalized Servicing Rights & $7.19 \%$ & Equipment Depreciation & $4.30 \%$ \\
Mortgages Soldwith Servicing Released & $27.09 \%$ & Technology-Related Expenses & $1.65 \%$ \\
Other Gains from Loan Sale & $-2.25 \%$ & Consulting/Legal Fees & $2.04 \%$ \\
Total Servicing-Related Non-Interest Income & $7.62 \%$ & & \\
Servicing Fees & $9.22 \%$ & & \\
Subservicing Fees & $1.22 \%$ & & 429 \\
Late Fees & $0.70 \%$ & & \\
Change in MSR Value & $-1.65 \%$ & & \\
MSR Sale & $0.05 \%$ & & \\
\hline No. of Institutions & 429 & & \\
\hline
\end{tabular}




\section{Table 2: Shadow Bank Call Reports - Liability and Equity Composition}

This table reports the liability and equity composition of shadow banks active in the US mortgage market in our sample ranging from 2011 Q1 to 2017 Q4. We restrict attention to mortgage companies that are required to file HMDA reports and originate mortgage loans. This restriction leaves us with 429 shadow banks that have a license in the two states that provided us data. The table shows the average liability and equity shares and 25 th, median and 75 th percentiles for liability and asset shares. Panel (b) presents statistics on the providers of the short-term warehouse line of credit to shadow banks. These lines of credit account for most of the shadow banks' debt. Panel (b) reports the number of creditors, the percentage of credit used (drawn) relative to the overall credit limit, and the dollar-weighted composition of creditors among credit lines provided and the credit lines used grouped by banks, government sponsored enterprises (GSEs), non-bank financial institutions, and other category. Data Sources: Shadow banks' quarterly call report filings.

Panel A: Shadow banks' liability and equity composition

\begin{tabular}{lcccc}
\hline \hline & Mean & $25^{\text {th }}$ & Median & $75^{\text {th }}$ \\
\cline { 2 - 5 } Total Liabilities & 74.98 & 69.59 & 80.89 & 87.18 \\
Short-term Liabilities & 66.18 & 56.91 & 75.45 & 83.78 \\
Debt Facilities & 59.42 & 48.28 & 69.45 & 78.8 \\
Commercial Papers & 0 & 0 & 0 & 0 \\
Other Account Payables & 1.98 & 0 & 0.02 & 1.23 \\
Accrued Expenses & 2.91 & 1.13 & 2.3 & 3.77 \\
Other Short-term Liabilities & 1.37 & 0 & 0.25 & 1.46 \\
Long-term Liabilities & 8.17 & 0.55 & 1.91 & 5.44 \\
Mortgage Debt & 1.65 & 0 & 0 & 0 \\
Trust Preferred Securities & 0 & 0 & 0 & 0 \\
Other Long-term Liabilities & 3.27 & 0 & 0 & 0.8 \\
Servicing Liabilities & 0.47 & 0 & 0 & 0 \\
Derivative Liabilities & 0.28 & 0 & 0 & 0.24 \\
Repurchase Reserves & 0.97 & 0 & 0.34 & 1.17 \\
Subordinated Debt & 0.07 & 0 & 0 & 0 \\
& & & & 30.32 \\
Total Equity & 24.9 & 12.68 & 19 & 0 \\
Preferred Stock & 0.24 & 0 & 0 & 8.78 \\
Common Stock (Partner's Capital) & 6.29 & 0 & 0.1 & 5.18 \\
Paid-in Capital & 6.75 & 0 & 0.71 & 0 \\
Non-control Interest & 0.01 & 0 & 0 & 0 \\
Other Comprehensive Income & 0.07 & 0 & 0 & 17.85 \\
Retained Earnings & 11.33 & 0 & 8.74 & 0 \\
Treasury Stocks & -0.1 & 0 & & \\
\hline No. of Institutions & 429 & & & \\
\hline \hline
\end{tabular}

Panel B: Providers of short-term warehouse lines of credit to shadow banks

\begin{tabular}{|c|c|c|c|c|}
\hline & Mean & $25^{\text {th }}$ & Median & $75^{\text {th }}$ \\
\hline Number of Creditors & 3.62 & 2 & 3 & 5 \\
\hline Credit Lines Used/ Credit Limit & $50.29 \%$ & $35.02 \%$ & $51.13 \%$ & $67.07 \%$ \\
\hline \multicolumn{5}{|c|}{ Credit Lines Limit: Lender Composition } \\
\hline Banks & $93.11 \%$ & $100 \%$ & $100 \%$ & $100 \%$ \\
\hline GSE & $0.70 \%$ & $0 \%$ & $0 \%$ & $0 \%$ \\
\hline Non-Bank Financial Institution & $5.78 \%$ & $0 \%$ & $0 \%$ & $0 \%$ \\
\hline Other & $0.42 \%$ & $0 \%$ & $0 \%$ & $0 \%$ \\
\hline \multicolumn{5}{|c|}{ Credit Lines Used: Lender Composition } \\
\hline Banks & $94.58 \%$ & $100 \%$ & $100 \%$ & $100 \%$ \\
\hline GSE & $0.40 \%$ & $0 \%$ & $0 \%$ & $0 \%$ \\
\hline Non-Bank Financial Institution & $4.59 \%$ & $0 \%$ & $0 \%$ & $0 \%$ \\
\hline Other & $0.43 \%$ & $0 \%$ & $0 \%$ & $0 \%$ \\
\hline No. of Institutions & 413 & & & \\
\hline
\end{tabular}




\section{Table 3: Summary Statistics - Shadow Bank versus Bank Funding Composition}

Panel (a) of this table compares average funding composition of shadow banks and banks during our sample period ranging from $2011 \mathrm{Q} 1$ to $2017 \mathrm{Q} 4$. We restrict attention to mortgage companies that are required to file HMDA reports and originate mortgage loans. Removing companies that do not show up in HMDA database, this restriction leaves us with 429 shadow banks that have a license in the two states that provide us data. Column (1) shows the statistics for the shadow bank sample. Column (2) for the full bank sample. Column (3) for originate-to-distribute (OTD) banks version I defined as banks whose percentage of mortgages sold in less than 1 year as recorded in HMDA is in the top five percent among all banks. The average percentage of mortgages sold of OTD banks is $92.4 \%$, while the minimum percentage of mortgages sold is $85.5 \%$. The average percentage of mortgages sold of shadow banks is $94.4 \%$. Column (4) shows these statistics for version II OTD banks defined as banks whose shares of loans held for sale out of total loans held on balance sheet are greater than $10 \%$ based on their call report data. We note that $10 \%$ share of loans held for sale threshold is broadly consistent with about $85.5 \%$ minimum threshold of mortgages sold out of total originated for OTD banks of version 1 (see Section 2E). Column (5) shows the statistics for the synthetic mortgage bank sample created by replacing all bank loans with mortgage loans while keeping all the other assets fixed. Panel (b) shows the distribution of equity to asset ratio for shadow banks and the above bank comparison groups. Data Sources: Shadow banks' quarterly call report filings to state regulators, bank regulatory call report filing, and HMDA.

Panel A: Funding composition of shadow banks and banks

\begin{tabular}{lccccc}
\hline \hline & $(1)$ & $(2)$ & $(3)$ & $(4)$ & $(5)$ \\
\hline & $\begin{array}{c}\text { Shadow } \\
\text { Bank } \\
\text { Sample }\end{array}$ & $\begin{array}{c}\text { Bank } \\
\text { Full } \\
\text { Sample }\end{array}$ & $\begin{array}{c}\text { OTD } \\
\text { Bank } \\
\text { I }\end{array}$ & $\begin{array}{c}\text { OTD } \\
\text { Bank } \\
\text { II }\end{array}$ & $\begin{array}{c}\text { Synthetic } \\
\text { Mortgage } \\
\text { Bank }\end{array}$ \\
\hline Total Liabilities & 75.0 & 89.1 & 89.3 & 89.6 & 88.1 \\
Short-term Liabilities & 66.2 & 76.5 & 76.0 & 76.9 & 60.7 \\
Debt Facilities & 59.4 & 73.1 & 71.4 & 69.7 & 54.6 \\
$\quad$ Insured & 0.0 & 49.6 & 48.5 & 45.4 & 50.4 \\
$\quad$ Uninsured & 59.4 & 23.4 & 22.8 & 24.4 & 4.3 \\
Long-term Liabilities & 8.2 & 12.6 & 13.3 & 12.5 & 27.2 \\
Equity & 24.9 & 10.9 & 10.7 & 10.4 & 11.9 \\
Preferred Stock & 0.2 & 0.1 & 0.1 & 0.1 & 0.0 \\
Common Stock & 6.3 & 1.0 & 1.0 & 1.0 & -1.2 \\
Paid-in Capital & 6.7 & 5.0 & 5.0 & 6.0 & 0.8 \\
Retained Earnings & 11.3 & 4.8 & 4.4 & 3.0 & 12.5 \\
\hline No. of Institutions & 429 & 4,822 & 549 & 257 & 4,822 \\
\hline \hline
\end{tabular}

Panel B: Distribution of equity to asset ratio for shadow banks and banks

\begin{tabular}{lccccccccc}
\hline \hline & $\begin{array}{c}\text { Asset- } \\
\text { Weighted } \\
\text { Mean }\end{array}$ & $\begin{array}{c}\text { Volume- } \\
\text { Weighted } \\
\text { Mean }\end{array}$ & Mean & S.D. & 10th & 25 & 50th & 75th & 90th \\
\hline Shadow Bank & 17.0 & 20.7 & 24.9 & 18.3 & 9.2 & 12.7 & 19.0 & 30.3 & 50.3 \\
Bank Full Sample & 11.5 & 11.2 & 10.9 & 2.9 & 8.2 & 9.2 & 10.4 & 12.1 & 14.3 \\
OTD Bank I & 10.2 & 10.5 & 10.7 & 2.8 & 7.9 & 9.1 & 10.2 & 11.8 & 13.9 \\
OTD Bank II & 10.5 & 10.6 & 10.4 & 2.9 & 7.4 & 8.8 & 10.1 & 11.6 & 13.3 \\
Synthetic Mortgage Bank & 11.6 & 11.4 & 11.9 & 2.8 & 9.1 & 10.2 & 11.5 & 13.1 & 15.2 \\
\hline \hline
\end{tabular}




\section{Table 4: Equity to Asset Ratio - Shadow Banks versus Banks}

This table reports results of OLS regression of equity to asset ratio on shadow bank indicator. The sample consists of shadow banks and all banks (Column 1 and 2), shadow banks and (originate-to-distribute) OTD banks of version I (Column 3 and 4), shadow banks and OTD banks of version II (Column 5 and 6), shadow banks and synthetic mortgage banks (Column 7 and 8). The OTD banks of version I are defined as banks whose percentage of mortgages sold in less than 1 year as recorded in HMDA in a given year is in the top five percent among all banks. The average percentage of mortgages sold among OTD banks I is $92.4 \%$, while the minimum percentage of mortgages sold is $85.5 \%$. The average percentage of mortgages sold of shadow banks is $94.4 \%$. In column (3) and (4) we also remove a few shadow banks whose percentage of mortgages sold is less than the OTD bank I threshold of $85.5 \%$. The OTD banks II are defined as banks whose shares of loans held for sale out of total loans held on balance sheet are greater than $10 \%$ based on their call report data. We note that $10 \%$ share of loans held for sale threshold is broadly consistent with the $85.5 \%$ minimum threshold of mortgages sold out of total originated among OTD banks I (see Section 2E). The synthetic mortgage bank sample is created by replacing all bank loans with mortgage loans while keeping all the other assets fixed. The year-quarter time fixed effects (Date FE) are included in all specifications. Institution controls include the asset growth, the share of refinanced mortgages out of total mortgage origination volume, the share of government-insured mortgages out of total mortgage origination volume, the logarithm of annual mortgage origination volume in dollars, the logarithm of asset size in dollars, the geographic loan dispersion, and the logarithm of the weighted average of income per capita in states of operation, where each state income per capita is weighted by the share of institution $i$ 's loan origination in this state out of total loan origination of institution $i$, as reported in HMDA. Standard errors in the parentheses are clustered by institution. Data Sources: Shadow banks' quarterly call report filings to state regulators, bank regulatory call report filings, and HMDA.

\begin{tabular}{|c|c|c|c|c|c|c|c|c|}
\hline \multirow[b]{3}{*}{ Shadow Bank } & \multicolumn{2}{|c|}{$\begin{array}{c}\text { Shadow Bank vs } \\
\text { All Bank }\end{array}$} & \multicolumn{2}{|c|}{$\begin{array}{c}\text { Shadow Bank vs } \\
\text { OTD Bank I }\end{array}$} & \multicolumn{2}{|c|}{$\begin{array}{l}\text { Shadow Bank vs } \\
\text { OTD Bank II }\end{array}$} & \multicolumn{2}{|c|}{$\begin{array}{l}\text { Shadow Bank vs } \\
\text { Synthetic } \\
\text { Mortgage Bank }\end{array}$} \\
\hline & (1) & (2) & (3) & (4) & (5) & (6) & (7) & $(8)$ \\
\hline & $\begin{array}{l}10.92 \\
(0.67) \\
\end{array}$ & $\begin{array}{l}11.26 \\
(0.85) \\
\end{array}$ & $\begin{array}{l}10.93 \\
(0.69) \\
\end{array}$ & $\begin{array}{l}12.30 \\
(1.17) \\
\end{array}$ & $\begin{array}{r}11.06 \\
(0.70) \\
\end{array}$ & $\begin{array}{l}11.85 \\
(1.22) \\
\end{array}$ & $\begin{array}{c}9.97 \\
(0.67) \\
\end{array}$ & $\begin{array}{l}10.12 \\
(0.85) \\
\end{array}$ \\
\hline Date FE & Yes & Yes & Yes & Yes & Yes & Yes & Yes & Yes \\
\hline Institution Controls & No & Yes & No & Yes & No & Yes & No & Yes \\
\hline Observations & 115,167 & 109,411 & 11,724 & 10,947 & 8,992 & 8,401 & 115,167 & 109,411 \\
\hline R2 & 0.253 & 0.258 & 0.230 & 0.292 & 0.157 & 0.242 & 0.223 & 0.230 \\
\hline Y-Variable Mean & 11.56 & 11.56 & 16.71 & 16.73 & 19.02 & 18.99 & 12.46 & 12.47 \\
\hline Shadow Banks & 21.91 & 21.97 & 21.93 & 22.02 & 21.91 & 21.97 & 21.91 & 21.97 \\
\hline Banks & 10.92 & 10.94 & 10.64 & 10.68 & 10.33 & 10.37 & 11.88 & 11.89 \\
\hline
\end{tabular}




\section{Table 5: Tier 1 Capital Ratio - Shadow Banks versus Banks}

This table reports results of OLS regressions of risk-based tier 1 capital ratio on shadow bank indicator. The sample consists of shadow banks and all banks (Column 1 and 2), shadow banks and OTD banks of version I (Column 3 and 4), shadow banks and OTD banks of version II (Column 5 and 6), shadow banks and synthetic mortgage banks which (Column 7 and 8). Since shadow banks do not report risk-based tier 1 capital ratios, we compute this ratio by applying the Basel III risk-based tier 1 capital ratio formula. Since we do not observe the detailed risk profiles for each type of assets held on the shadow banks' balance sheet, we use the upper bound and lower bound of shadow banks' tier 1 capital ratios in panel (a) and (b), respectively. These bounds are computed as described in Section 2.D. The OTD banks of version I are defined as banks whose percentage of mortgages sold in less than 1 year as recorded in HMDA in a given year is in the top five percent among all banks. The average percentage of mortgages sold among OTD banks I is $92.4 \%$, while the minimum percentage of mortgages sold is $85.5 \%$. The average percentage of mortgages sold of shadow banks is $94.4 \%$. In column (3) and (4) we also remove a few shadow banks whose percentage of mortgages sold is less than the OTD bank I threshold of $85.5 \%$. The OTD banks II are defined as banks whose shares of loans held for sale out of total loans held on balance sheet are greater than $10 \%$ based on their call report data. We note that $10 \%$ share of loans held for sale threshold is broadly consistent with the $85.5 \%$ minimum threshold of mortgages sold out of total originated among OTD banks I (see Section 2E). The synthetic mortgage bank sample is created by replacing all bank loans with mortgage loans while keeping all the other assets fixed. The year-quarter time fixed effects (Date FE) are included in all specifications. Institution controls include asset growth, the share of refinanced mortgages out of total mortgage origination volume, the share of governmentinsured mortgages out of total mortgage origination volume, the logarithm of annual mortgage origination volume in dollars, the logarithm of asset size in dollars, the geographic loan dispersion, and the logarithm of the weighted average of income per capita in states of operation, where each state income per capita is weighted by the share of institution $i$ 's loan origination in this state out of total loan origination of institution $i$, as reported in HMDA. Standard errors in the parentheses are clustered by institution. Data Sources: Shadow banks' quarterly call report filings to state regulators, bank regulatory call report filings, and HMDA.

Panel A: Tier 1 capital ratio (upper bound)

\begin{tabular}{|c|c|c|c|c|c|c|c|c|}
\hline \multirow[b]{3}{*}{ Shadow Bank } & \multicolumn{2}{|c|}{$\begin{array}{l}\text { Shadow Bank vs } \\
\text { All Bank }\end{array}$} & \multicolumn{2}{|c|}{$\begin{array}{c}\text { Shadow Bank vs } \\
\text { OTD Bank I }\end{array}$} & \multicolumn{2}{|c|}{$\begin{array}{l}\text { Shadow Bank vs } \\
\text { OTD Bank II }\end{array}$} & \multicolumn{2}{|c|}{$\begin{array}{c}\text { Shadow Bank vs } \\
\text { Synthetic } \\
\text { Mortgage Bank }\end{array}$} \\
\hline & (1) & (2) & (3) & (4) & (5) & (6) & (7) & $(8)$ \\
\hline & $\begin{array}{l}20.84 \\
(0.83)\end{array}$ & $\begin{array}{l}21.05 \\
(1.08)\end{array}$ & $\begin{array}{l}21.54 \\
(0.92)\end{array}$ & $\begin{array}{l}21.47 \\
(1.41)\end{array}$ & $\begin{array}{l}21.30 \\
(0.94)\end{array}$ & $\begin{array}{l}19.39 \\
(1.61)\end{array}$ & $\begin{array}{l}15.48 \\
(0.82)\end{array}$ & $\begin{array}{l}14.57 \\
(1.06)\end{array}$ \\
\hline Date FE & Yes & Yes & Yes & Yes & Yes & Yes & Yes & Yes \\
\hline Institution Controls & No & Yes & No & Yes & No & Yes & No & Yes \\
\hline Observations & 115,167 & 109,411 & 11,724 & 10,947 & 8,992 & 8,401 & 115,167 & 109,411 \\
\hline R2 & 0.255 & 0.289 & 0.357 & 0.410 & 0.245 & 0.311 & 0.202 & 0.234 \\
\hline Y-Variable Mean & 17.35 & 17.33 & 27.19 & 27.18 & 31.65 & 31.59 & 22.36 & 22.37 \\
\hline Shadow Banks & 37.06 & 37.20 & 37.24 & 37.37 & 37.06 & 37.20 & 37.06 & 37.20 \\
\hline Banks & 16.12 & 16.13 & 15.50 & 15.53 & 15.41 & 15.40 & 21.45 & 21.47 \\
\hline
\end{tabular}

Panel B: Tier 1 capital ratio (lower bound)

\begin{tabular}{|c|c|c|c|c|c|c|c|c|}
\hline \multirow[b]{3}{*}{ Shadow Bank } & \multicolumn{2}{|c|}{$\begin{array}{l}\text { Shadow Bank vs } \\
\text { All Bank }\end{array}$} & \multicolumn{2}{|c|}{$\begin{array}{c}\text { Shadow Bank vs } \\
\text { OTD Bank I }\end{array}$} & \multicolumn{2}{|c|}{$\begin{array}{l}\text { Shadow Bank vs } \\
\text { OTD Bank II }\end{array}$} & \multicolumn{2}{|c|}{$\begin{array}{c}\text { Shadow Bank vs } \\
\text { Synthetic } \\
\text { Mortgage Bank }\end{array}$} \\
\hline & $(1)$ & $(2)$ & (3) & (4) & (5) & (6) & (7) & $(8)$ \\
\hline & $\begin{array}{l}10.98 \\
(0.72)\end{array}$ & $\begin{array}{l}11.01 \\
(0.94)\end{array}$ & $\begin{array}{l}11.52 \\
(0.83)\end{array}$ & $\begin{array}{l}11.32 \\
(1.28)\end{array}$ & $\begin{array}{l}11.37 \\
(0.85)\end{array}$ & $\begin{array}{c}9.68 \\
(1.47)\end{array}$ & $\begin{array}{c}5.62 \\
(0.71)\end{array}$ & $\begin{array}{c}4.53 \\
(0.91)\end{array}$ \\
\hline Date FE & Yes & Yes & Yes & Yes & Yes & Yes & Yes & Yes \\
\hline Institution Controls & No & Yes & No & Yes & No & Yes & No & Yes \\
\hline Observations & 115,167 & 109,411 & 11,724 & 10,947 & 8,992 & 8,401 & 115,167 & 109,411 \\
\hline R2 & 0.098 & 0.138 & 0.189 & 0.251 & 0.128 & 0.204 & 0.042 & 0.077 \\
\hline Y-Variable Mean & 16.77 & 16.77 & 21.85 & 21.85 & 24.26 & 24.20 & 21.79 & 21.80 \\
\hline Shadow Banks & 27.20 & 27.25 & 27.32 & 27.37 & 27.20 & 27.25 & 27.20 & 27.25 \\
\hline Banks & 16.12 & 16.13 & 15.50 & 15.53 & 15.41 & 15.40 & 21.45 & 21.47 \\
\hline
\end{tabular}




\section{Table 6: Short-Term Debt to Total Debt - Shadow Banks vs Banks}

This table reports results of OLS regressions of short-term debt to total debt on shadow bank indicator. Short-term debt is defined as funding with less than 1-year time to maturity or repricing. For shadow banks we treat all debt items that are classified as "short-term liabilities" in the call reports as short-term debt. When computing short-term debt for banks, we add short-term deposits (time deposits with more than 1-year maturity are excluded), repo, shortterm borrowings and trading liabilities. The sample consists of shadow banks and all banks (Column 1 and 2), shadow banks and OTD banks of version I (Column 3 and 4), shadow banks and OTD banks of version II (Column 5 and 6), shadow banks and synthetic mortgage banks which (Column 7 and 8). The OTD banks of version I are defined as banks whose percentage of mortgages sold in less than 1 year as recorded in HMDA in a given year is in the top five percent among all banks. The average percentage of mortgages sold among OTD banks I is $92.4 \%$, while the minimum percentage of mortgages sold is $85.5 \%$. The average percentage of mortgages sold of shadow banks is $94.4 \%$. In column (3) and (4) we also remove a few shadow banks whose percentage of mortgages sold is less than the OTD bank I threshold of $85.5 \%$. The OTD banks II are defined as banks whose shares of loans held for sale out of total loans held on balance sheet are greater than $10 \%$ based on their call report data. We note that $10 \%$ share of loans held for sale threshold is broadly consistent with the $85.5 \%$ minimum threshold of mortgages sold out of total originated among OTD banks I (see Section 2E). The synthetic mortgage bank sample is created by replacing all bank loans with mortgage loans while keeping all the other assets fixed. The year-quarter time fixed effects (Date FE) are included in all specifications. Institution controls include the asset growth, the share of refinanced mortgages out of total mortgage origination volume, the share of government-insured mortgages out of total mortgage origination volume, the logarithm of annual mortgage origination volume in dollars, the logarithm of asset size in dollars, the geographic loan dispersion, and the logarithm of the weighted average of income per capita in states of operation, where each state income per capita is weighted by the share of institution $i$ 's loan origination in this state out of total loan origination of institution $i$, as reported in HMDA. Standard errors in the parentheses are clustered by institution. Data Sources: Shadow banks' quarterly call report filings to state regulators, bank regulatory call report filings, and HMDA.

\begin{tabular}{|c|c|c|c|c|c|c|c|c|}
\hline \multirow{4}{*}{ Shadow Bank } & \multicolumn{2}{|c|}{$\begin{array}{c}\text { Shadow Bank vs } \\
\text { All Bank }\end{array}$} & \multicolumn{2}{|c|}{$\begin{array}{l}\text { Shadow Bank vs } \\
\text { OTD Bank I }\end{array}$} & \multicolumn{2}{|c|}{$\begin{array}{l}\text { Shadow Bank vs } \\
\text { OTD Bank II }\end{array}$} & \multicolumn{2}{|c|}{$\begin{array}{c}\text { Shadow Bank vs } \\
\text { Synthetic } \\
\text { Mortgage Bank }\end{array}$} \\
\hline & $(1)$ & $(2)$ & $(3)$ & $(4)$ & $(5)$ & $(6)$ & $(7)$ & $(8)$ \\
\hline & 11.97 & 16.44 & 12.57 & 10.11 & 12.07 & 9.34 & 28.84 & 28.04 \\
\hline & $(0.52)$ & $(1.03)$ & $(0.75)$ & $(1.76)$ & $(0.86)$ & $(1.73)$ & $(0.52)$ & $(0.94)$ \\
\hline Date FE & Yes & Yes & Yes & Yes & Yes & Yes & Yes & Yes \\
\hline Institution Controls & No & Yes & No & Yes & No & Yes & No & Yes \\
\hline Observations & 114,780 & 109,067 & 11,445 & 10,696 & 8,605 & 8,057 & 114,780 & 109,067 \\
\hline $\mathrm{R} 2$ & 0.094 & 0.111 & 0.286 & 0.316 & 0.209 & 0.263 & 0.381 & 0.397 \\
\hline Y-Variable Mean & 86.48 & 86.55 & 91.90 & 91.90 & 94.87 & 94.80 & 70.44 & 70.49 \\
\hline Shadow Banks & 98.09 & 98.06 & 98.10 & 98.08 & 98.09 & 98.06 & 98.09 & 98.06 \\
\hline Banks & 85.80 & 85.89 & 85.01 & 85.13 & 85.78 & 85.90 & 68.82 & 68.92 \\
\hline
\end{tabular}




\section{Table 7: Equity to Asset Ratio and Size - Shadow Banks vs Banks}

This table reports results of OLS regression of equity to asset ratio on shadow bank indicator, and its interaction with size. The size is measured by the logarithm of annual mortgage origination volume in dollars (Loan Volume). The sample consists of shadow banks and all banks (Column 1), shadow banks and OTD banks of version I (Column 2), shadow banks and OTD banks of version II (Column 3), shadow banks and synthetic mortgage banks which are constructed by replacing all bank assets with residential mortgages (Column 4). The OTD banks of version I are defined as banks whose percentage of mortgages sold in less than 1 year as recorded in HMDA in a given year is in the top five percent among all banks. The average percentage of mortgages sold among OTD banks I is $92.4 \%$, while the minimum percentage of mortgages sold is $85.5 \%$. The average percentage of mortgages sold of shadow banks is $94.4 \%$. In column (2) we also remove a few shadow banks whose percentage of mortgages sold is less than the OTD bank I threshold of $85.5 \%$. The OTD banks II are defined as banks whose shares of loans held for sale out of total loans held on balance sheet are greater than $10 \%$ based on their call report data. We note that $10 \%$ share of loans held for sale threshold is broadly consistent with the $85.5 \%$ minimum threshold of mortgages sold out of total originated among OTD banks I (see Section 2E). The synthetic mortgage bank sample is created by replacing all bank loans with mortgage loans while keeping all the other assets fixed. The year-quarter time fixed effects (Date $F E)$ are included in all specifications. Institution controls include the asset growth, the share of refinanced mortgages out of total mortgage origination volume, the share of government-insured mortgages out of total mortgage origination volume, the logarithm of annual mortgage origination volume in dollars, the geographic loan dispersion, and the logarithm of the weighted average of income per capita in states of operation, where each state income per capita is weighted by the share of institution $i$ 's loan origination in this state out of total loan origination of institution $i$, as reported in HMDA. The estimated coefficient of the interaction term of shadow bank indicator with loan volume is scaled by one standard deviation of loan volume. Standard errors in the parentheses are clustered by institution. Data Sources: Shadow banks' quarterly call report filings to state regulators, bank regulatory call report filings, and HMDA.

\begin{tabular}{lcccc}
\hline \hline & $\begin{array}{c}\text { Shadow Bank vs } \\
\text { All Bank }\end{array}$ & $\begin{array}{c}\text { Shadow Bank vs } \\
\text { OTD Bank I }\end{array}$ & $\begin{array}{c}\text { Shadow Bank vs } \\
\text { OTD Bank II }\end{array}$ & $\begin{array}{c}\text { Shadow Bank vs } \\
\text { Synthetic } \\
\text { Mortgage Bank }\end{array}$ \\
\cline { 2 - 5 } & $(1)$ & $(2)$ & $(3)$ & $(4)$ \\
\cline { 2 - 5 } Shadow Bank & 82.40 & 77.81 & 82.71 & 80.78 \\
Shadow Bank $\times$ Loan Volume & $(11.05)$ & $(11.99)$ & $(11.06)$ & $(11.06)$ \\
\hline Date FE & -6.70 & -6.24 & -6.73 & -6.63 \\
Institution Controls & $(1.03)$ & $(1.12)$ & $(1.03)$ & $(1.03)$ \\
Observations & Yes & Yes & Yes & Yes \\
R2 & Yes & Yes & Yes & Yes \\
Y-Variable Mean & 109,411 & 10,947 & 8,401 & 109,411 \\
\multicolumn{1}{c}{ Shadow Banks } & 0.304 & 0.320 & 0.268 & 0.277 \\
\multicolumn{1}{c}{ Banks } & 11.56 & 16.73 & 18.99 & 12.47 \\
\hline \hline
\end{tabular}




\section{Table 8: Uninsured Leverage and Size - Shadow Banks vs Banks}

This table reports results of OLS regression of uninsured leverage defined as the uninsured debt to asset ratio on size for shadow banks (panel a) and banks (panel b). The size is measured by the logarithm of annual mortgage origination volume in dollars (Loan Volume). For shadow banks all debt items as uninsured. For banks uninsured debt is defined as total debt less insured deposits. In panel (b) the sample consists of all banks (Column 1 and 2), OTD banks I (Column 3 and 4), OTD banks II (Column 5 and 6), and synthetic mortgage banks (Column 7 and 8). The OTD banks of version I are defined as banks whose percentage of mortgages sold in less than 1 year as recorded in HMDA in a given year is in the top five percent among all banks. The average percentage of mortgages sold among OTD banks I is $92.4 \%$, while the minimum percentage of mortgages sold is $85.5 \%$. The average percentage of mortgages sold of shadow banks is $94.4 \%$. The OTD banks II are defined as banks whose shares of loans held for sale out of total loans held on balance sheet are greater than $10 \%$ based on their call report data. We note that $10 \%$ share of loans held for sale threshold is broadly consistent with the $85.5 \%$ minimum threshold of mortgages sold out of total originated among OTD banks I (see Section 2E). The synthetic mortgage bank sample is created by replacing all bank loans with mortgage loans while keeping all the other assets fixed. The year-quarter time fixed effects (Date FE) are included in all specifications. Institution controls include the asset growth, the share of refinanced mortgages out of total mortgage origination volume, the share of government-insured mortgages out of total mortgage origination volume, the geographic loan dispersion, and the logarithm of the weighted average of income per capita in states of operation, where each state income per capita is weighted by the share of institution $i$ 's loan origination in this state out of total loan origination of institution $i$, as reported in HMDA. The estimated coefficient of loan volume is scaled by one standard deviation of loan volume. Standard errors in the parentheses are clustered by institution. Data Sources: Shadow banks' quarterly call report filings to state regulators, bank regulatory call report filings, and HMDA.

Panel A: Debt to asset ratio for shadow banks

\begin{tabular}{lcc}
\hline \hline & \multicolumn{2}{c}{ Shadow Bank } \\
\cline { 2 - 3 } Loan Volume & $(1)$ & $(2)$ \\
\cline { 2 - 3 } & 6.61 & 10.75 \\
& $(0.49)$ & $(1.62)$ \\
\hline Date FE & Yes & Yes \\
Institution Controls & No & Yes \\
Observations & 6,744 & 6,241 \\
R2 & 0.897 & 0.907 \\
Y-Variable Mean & 64.30 & 64.16 \\
\hline \hline
\end{tabular}

Panel B: Uninsured debt to asset ratio for banks

\begin{tabular}{lcccccccc}
\hline \hline & \multicolumn{2}{c}{ All Bank } & \multicolumn{2}{c}{ OTD Bank I } & \multicolumn{2}{c}{ OTD Bank II } & \multicolumn{2}{c}{ Synthetic } \\
Mortgage Bank
\end{tabular}




\section{Table 9: Uninsured Debt Cost and Size - Shadow Banks vs Banks}

This table reports regression results of average annual interest rate on shadow bank debt (Column 1 and 2), annual uninsured bank debt (Column 3 and 4), and an annual uninsured-insured debt interest rate spread for banks (Column 5 and 6), all in percentage points, on size measured by the logarithm of annual mortgage origination volume in dollars (Loan Volume). We note that all shadow bank debt is uninsured. The uninsuredinsured interest rate spread is defined as within bank difference between interest rate on uninsured and insured debt. The year fixed effects (Date FE) are included in all specifications. Institution controls include annual asset growth, the share of refinanced mortgages out of total mortgage origination volume, the share of governmentinsured mortgages out of total mortgage origination volume, the geographic loan dispersion, and the logarithm of the weighted average of income per capita in states of operation, where each state income per capita is weighted by the share of institution $i$ 's loan origination in this state out of total loan origination of institution $i$, as reported in HMDA. The estimated coefficient of loan volume is scaled by one standard deviation of loan volume. Standard errors in the parentheses are clustered by institution. Data Sources: Shadow banks' quarterly call report filings to state regulators, bank regulatory call report filings, and HMDA.

\begin{tabular}{lcccccc}
\hline \hline & \multicolumn{2}{c}{$\begin{array}{c}\text { Shadow Bank Sample } \\
\text { Interest Rate }\end{array}$} & \multicolumn{2}{c}{$\begin{array}{c}\text { Full Bank Sample } \\
\text { Interest Rate }\end{array}$} & \multicolumn{2}{c}{$\begin{array}{c}\text { Full Bank Sample } \\
\text { Uninsured-Insured Spread }\end{array}$} \\
\cline { 2 - 7 } & \multicolumn{1}{c}{$(1)$} & $(2)$ & $(3)$ & $(4)$ & $(5)$ & $(6)$ \\
\cline { 2 - 7 } Loan Volume & -1.10 & -0.98 & -0.21 & -0.23 & -0.28 & -0.30 \\
& $(0.12)$ & $(0.12)$ & $(0.01)$ & $(0.01)$ & $(0.01)$ & $(0.01)$ \\
\hline Institution Controls & No & Yes & No & Yes & No & Yes \\
Year FE & Yes & Yes & Yes & Yes & Yes & Yes \\
Observations & 2,015 & 1,823 & 27,270 & 27,137 & 27,270 & 27,137 \\
R2 & 0.080 & 0.081 & 0.320 & 0.344 & 0.268 & 0.299 \\
Y-Variable Mean & 4.42 & 3.97 & 2.33 & 2.33 & 1.25 & 1.25 \\
\hline \hline
\end{tabular}




\section{Figure 1: Sample Coverage}

This figure compares our sample coverage to the shadow bank loan origination coverage recorded in the HMDA data. Panel (a) plots the total shadow bank loan origination (in \$bn) with the loan origination from our sample coverage, by year. Panel (b) plots the histograms (frequency) of the logarithm of loan origination size for shadow banks in our sample as well as shadow banks in the HMDA data in 2017.

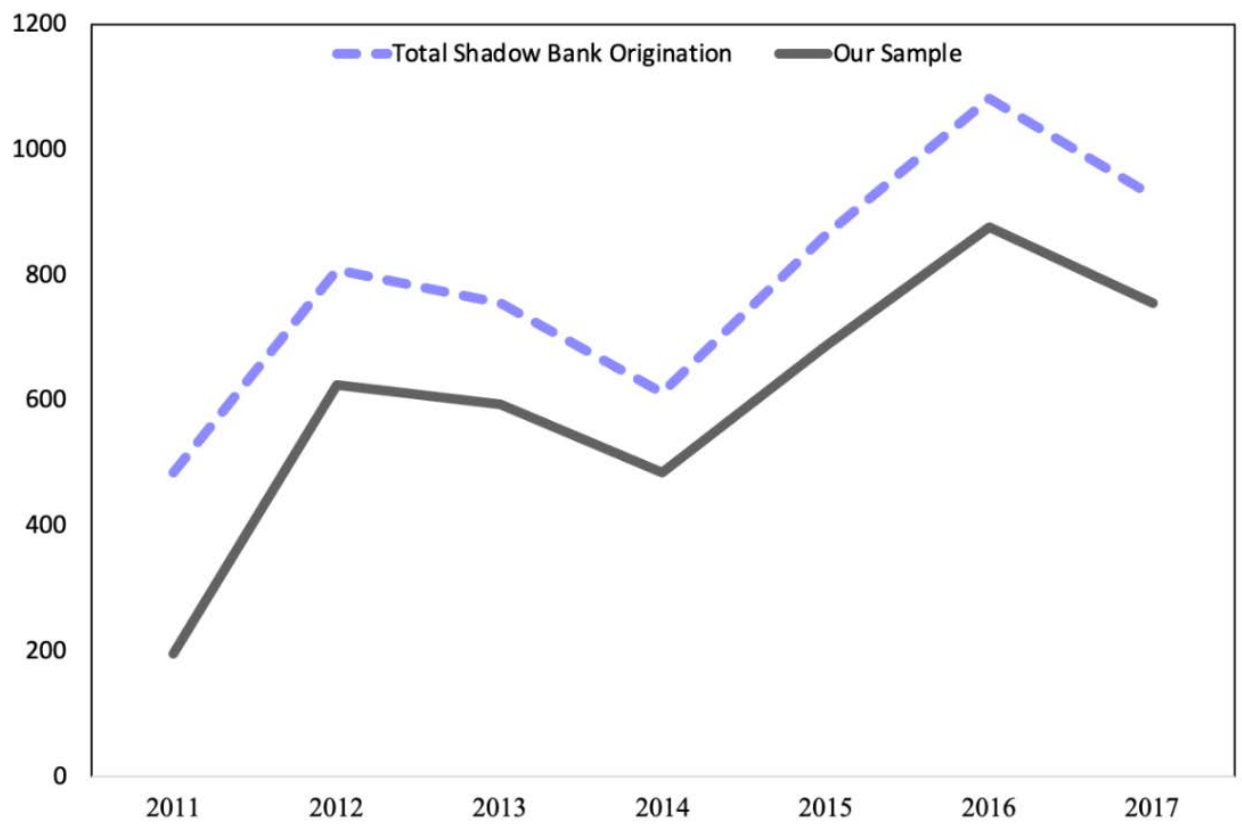

(a) Sample Coverage by Year

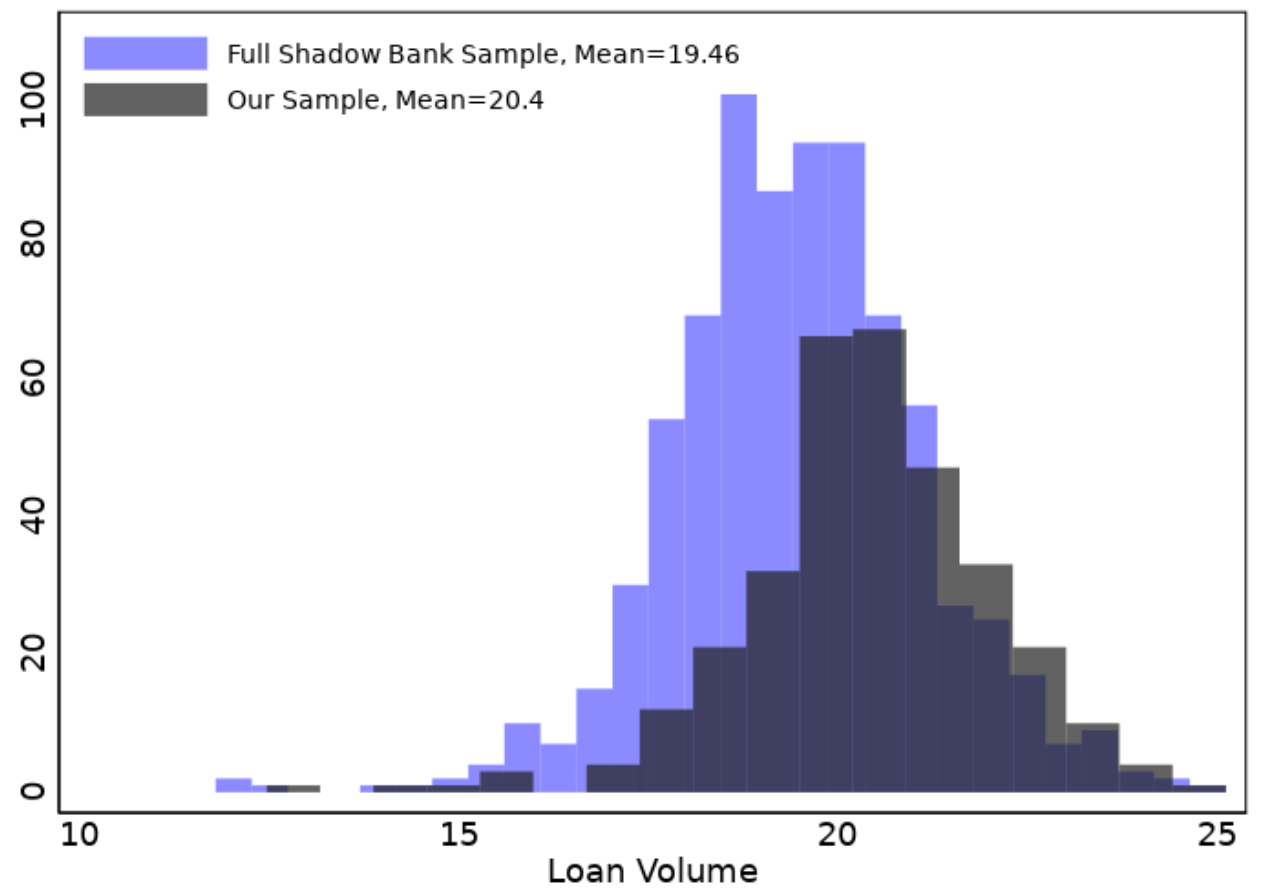

(b) 2017 Sample Size Distribution 


\section{Figure 2: Histograms for Shadow Bank and All Bank}

This figure plots the histograms (density) of the logarithm of annual loan origination volume in dollars (panel a) and the logarithm of assets in dollars (panel b) for shadow banks and banks in our sample. Data Sources: Shadow banks' quarterly call report filings to state regulators, bank regulatory call report filings, and HMDA.

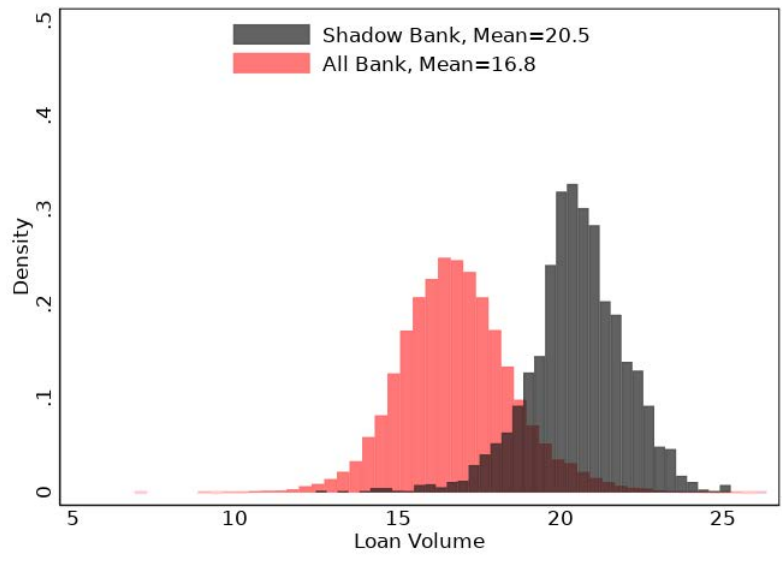

(a) Loan Volume Distribution

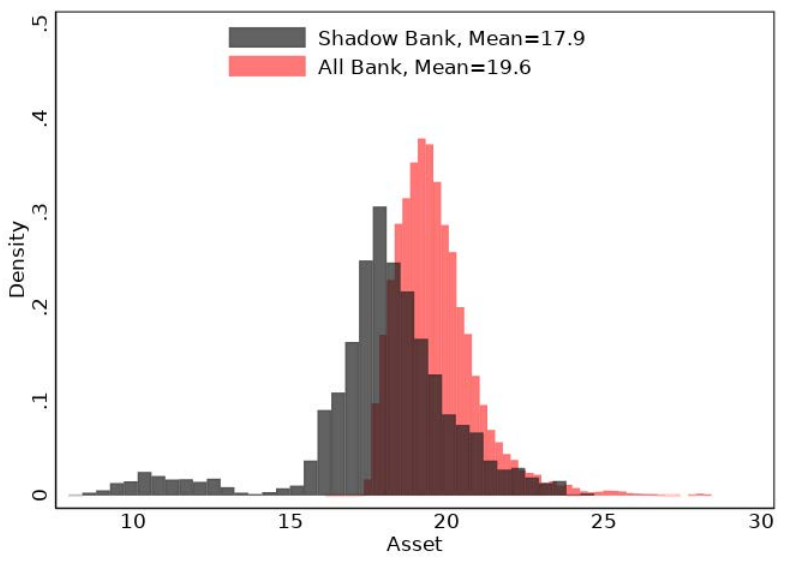

(b) Asset Distribution 


\section{Figure 3: Equity to Asset Ratio - Shadow Banks vs Banks}

This figure plots the histograms (density) of equity to asset ratio for shadow banks and banks. Panel (a) compares shadow banks to all banks, panel (b) shadow banks to OTD banks of version I, panel (c) shadow banks to OTD banks of version II, panel (d) shadow banks to synthetic mortgage banks. The OTD banks of version I are defined as banks whose percentage of mortgages sold in less than 1 year as recorded in HMDA is in the top decile among all banks. The average percentage of mortgages sold among OTD banks I is $92.4 \%$, while the minimum percentage of mortgages sold is $85.5 \%$. The average percentage of mortgages sold among shadow banks is $94.4 \%$. In panel (b) we also remove a few shadow banks whose percentage of mortgages sold is less than the OTD bank I threshold of $85.5 \%$. The OTD banks II are defined as banks whose shares of loans held for sale out of total loans held on balance sheet are greater than $10 \%$ based on their call report data. We note that $10 \%$ share of loans held for sale threshold is broadly consistent with about $86 \%$ threshold of mortgages sold out of total originated that we use to define OTD banks I (see Section 2.E). The synthetic mortgage bank sample is created by replacing all bank loans with mortgage loans while keeping all the other assets fixed. Data Sources: Shadow banks' quarterly call report filings to state regulators and bank regulatory call report filings.

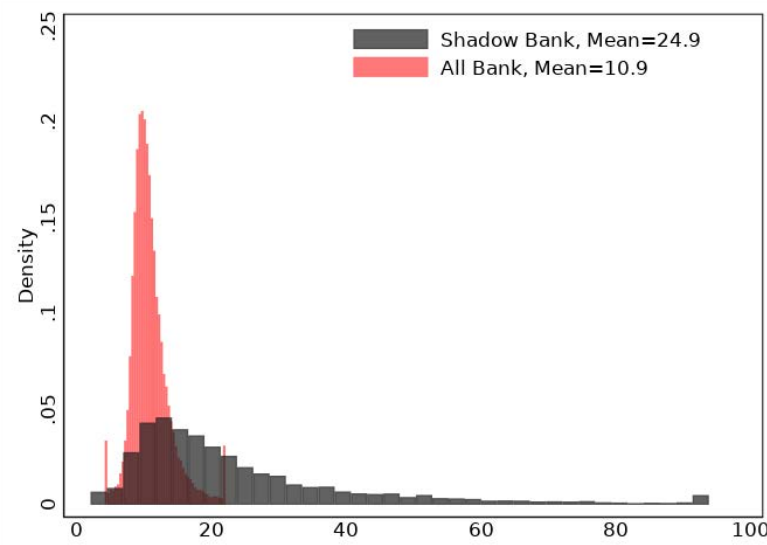

(a) Shadow Bank vs All Bank

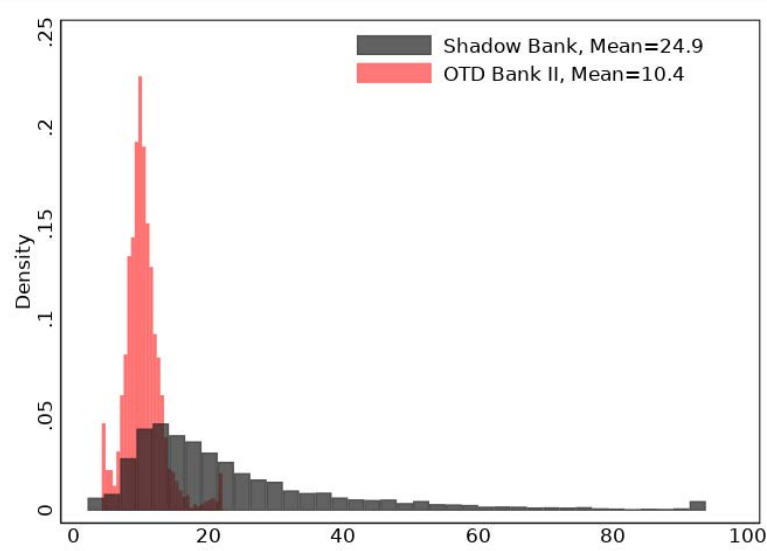

(c) Shadow Bank vs OTD Bank II

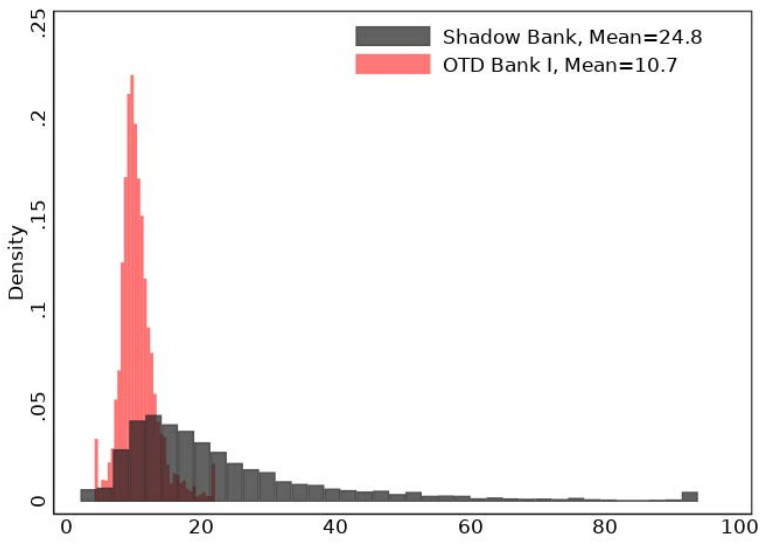

(b) Shadow Bank vs OTD Bank I

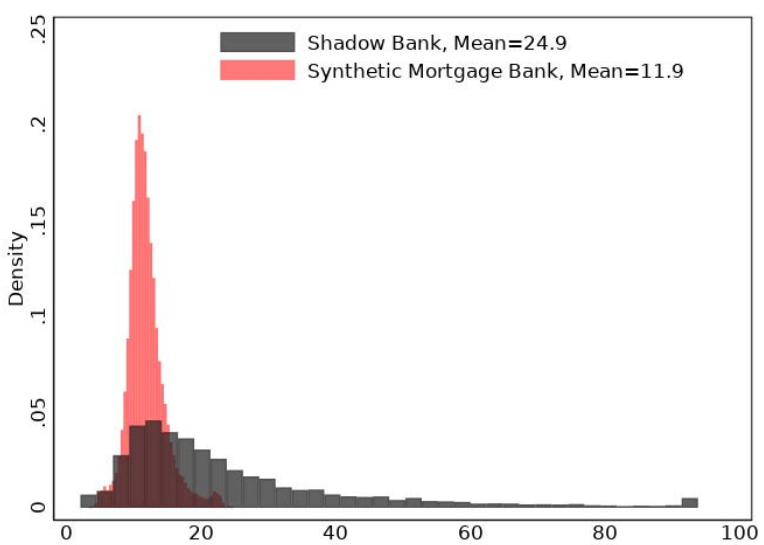

(d) Shadow Bank vs Synthetic Mortgage Bank 


\section{Figure 4: Equity to Asset Ratio over Time - Shadow Banks vs Banks}

This figure plots the time series of equity to asset ratio for shadow banks and banks. Panel (a) compares shadow banks to all banks, panel (b) shadow banks to OTD banks of version I, panel (c) shadow banks to OTD banks of version II, panel (d) shadow banks to synthetic mortgage banks which are constructed by replacing all bank assets with residential mortgages. The OTD banks of version I are defined as banks whose percentage of mortgages sold in less than 1 year as recorded in HMDA in a given year is in the top five percent among all banks. The average percentage of mortgages sold among OTD banks I is $92.4 \%$, while the minimum percentage of mortgages sold is $85.5 \%$. The average percentage of mortgages sold of shadow banks is $94.4 \%$. In panel (b) we also remove a few shadow banks whose percentage of mortgages sold is less than the OTD bank I threshold of $85.5 \%$. The OTD banks II are defined as banks whose shares of loans held for sale out of total loans held on balance sheet are greater than $10 \%$ based on their call report data. We note that $10 \%$ share of loans held for sale threshold is broadly consistent with the $85.5 \%$ minimum threshold of mortgages sold out of total originated among OTD banks I (see Section 2E). The synthetic mortgage bank sample is created by replacing all bank loans with mortgage loans while keeping all the other assets fixed. Data Sources: Shadow banks' quarterly call report filings to state regulators and bank regulatory call report filings.

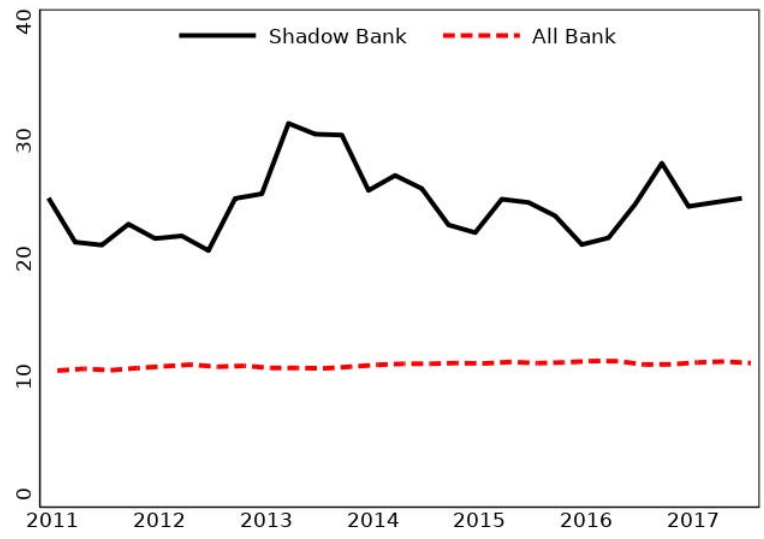

(a) Shadow Bank vs All Bank

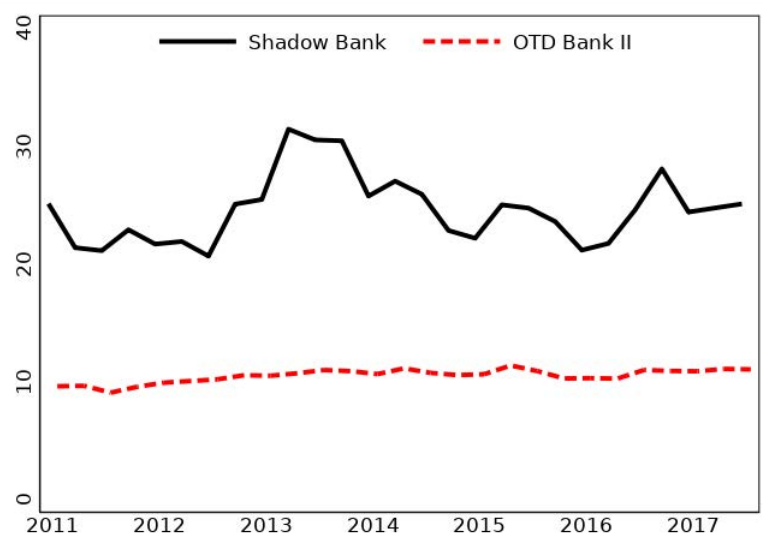

(c) Shadow Bank vs OTD Bank II

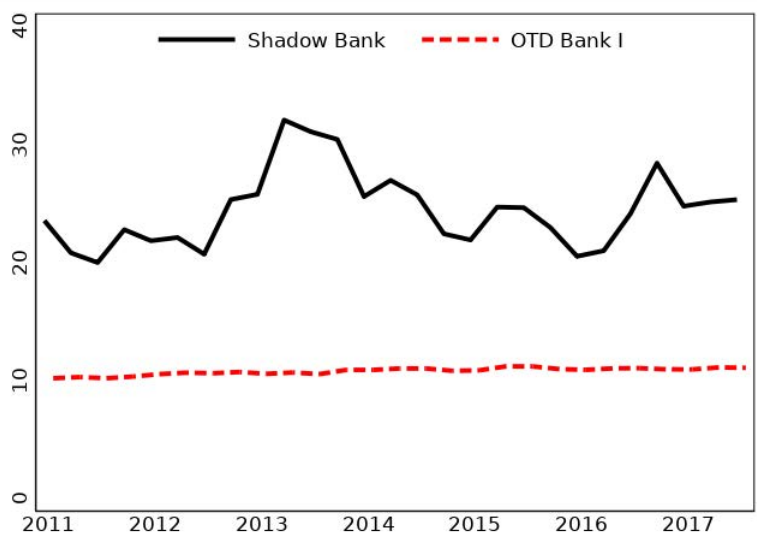

(b) Shadow Bank vs OTD Bank I

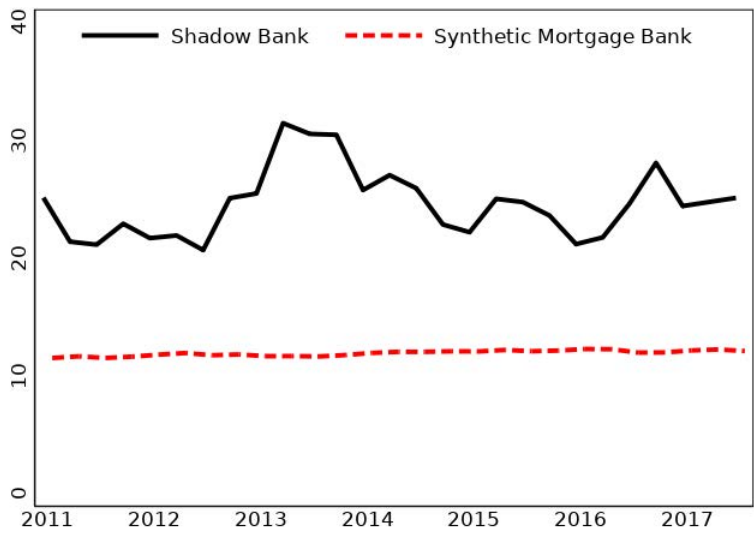

(d) Shadow Bank vs Synthetic Mortgage Bank 


\section{Figure 5: Tier 1 Capital Ratio - Shadow Banks vs Banks}

This figure plots the tier 1 capital ratio for shadow banks and banks. Panel (a) compares shadow banks to all banks, panel (b) shadow banks to OTD banks of type I, panel (c) shadow banks to OTD banks of type II, panel (d) shadow banks to synthetic mortgage banks. Since shadow banks do not report risk-based tier 1 capital ratios, we compute this ratio by applying the Basel III risk-based tier 1 capital ratio formula. Since we do not observe the detailed risk profiles for each type of assets held on the shadow banks' balance sheet, we use the upper bound and lower bound of shadow banks' tier 1 capital ratios, respectively. These bounds are computed as described in Section 2.D. The OTD banks of version I are defined as banks whose percentage of mortgages sold in less than 1 year as recorded in HMDA in a given year is in the top five percent among all banks. The average percentage of mortgages sold among OTD banks I is $92.4 \%$, while the minimum percentage of mortgages sold is $85.5 \%$. The average percentage of mortgages sold of shadow banks is $94.4 \%$. In panel (b) we also remove a few shadow banks whose percentage of mortgages sold is less than the OTD bank I threshold of $85.5 \%$. The OTD banks II are defined as banks whose shares of loans held for sale out of total loans held on balance sheet are greater than $10 \%$ based on their call report data. We note that $10 \%$ share of loans held for sale threshold is broadly consistent with the $85.5 \%$ minimum threshold of mortgages sold out of total originated among OTD banks I (see Section 2E). The synthetic mortgage bank sample is created by replacing all bank loans with mortgage loans while keeping all the other assets fixed. Data Sources: Shadow banks' quarterly call report filings to state regulators and bank regulatory call report filings.

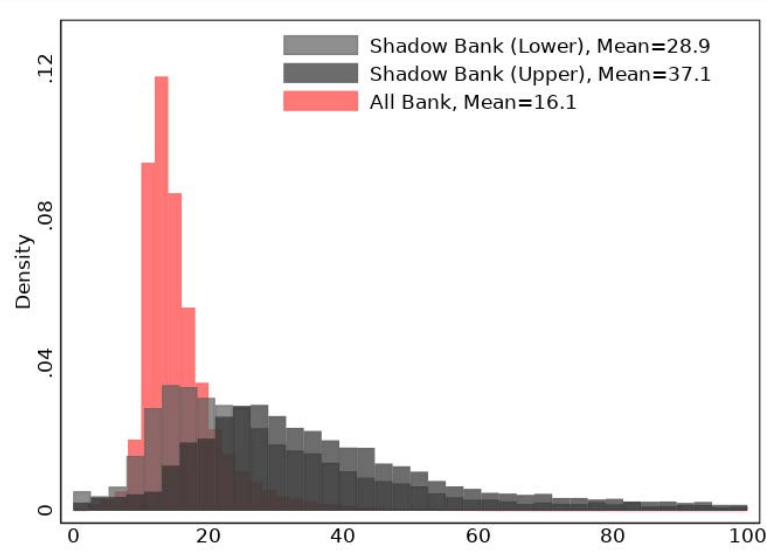

(a) Shadow Bank vs All Bank

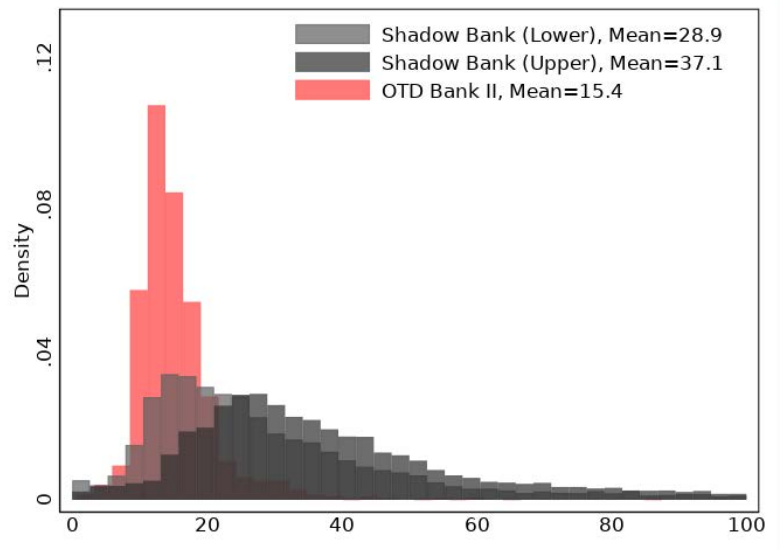

(c) Shadow Bank vs OTD Bank II

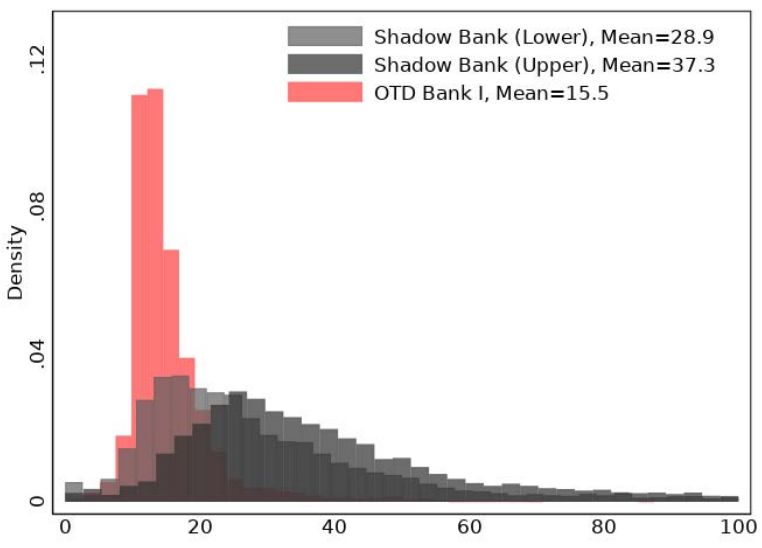

(b) Shadow Bank vs OTD Bank I

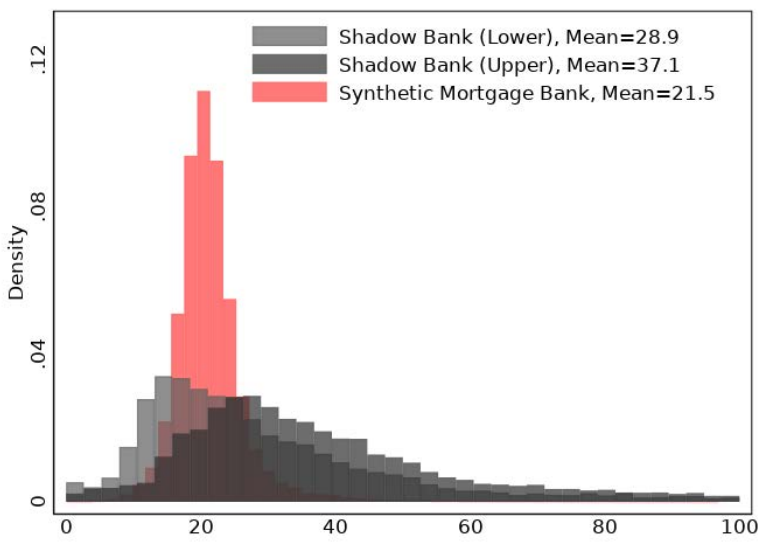

(d) Shadow Bank vs Synthetic Mortgage Bank 


\section{Figure 6: Short-Term Debt to Total Debt - Shadow Banks vs Banks}

This figure plots the histograms of short-term debt to total debt for shadow banks and banks. Panel (a) compares shadow banks to all banks, panel (b) shadow banks to OTD banks of version I, panel (c) shadow banks to OTD banks of version II, panel (d) shadow banks to synthetic mortgage banks. The OTD banks of version I are defined as banks whose percentage of mortgages sold in less than 1 year as recorded in HMDA in a given year is in the top five percent among all banks. The average percentage of mortgages sold among OTD banks I is $92.4 \%$, while the minimum percentage of mortgages sold is $85.5 \%$. The average percentage of mortgages sold of shadow banks is $94.4 \%$. In panel (b) we also remove a few shadow banks whose percentage of mortgages sold is less than the OTD bank I threshold of 85.5\%. The OTD banks II are defined as banks whose shares of loans held for sale out of total loans held on balance sheet are greater than $10 \%$ based on their call report data. We note that $10 \%$ share of loans held for sale threshold is broadly consistent with the $85.5 \%$ minimum threshold of mortgages sold out of total originated among OTD banks I (see Section 2E). The synthetic mortgage bank sample is created by replacing all bank loans with mortgage loans while keeping all the other assets fixed. Data Sources: Shadow banks' quarterly call report filings to state regulators and bank regulatory call report filings.

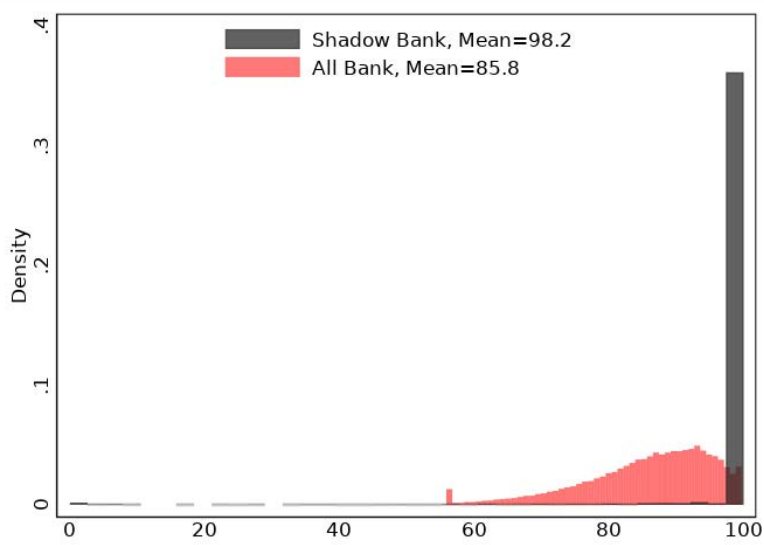

(a) Shadow Bank vs All Bank

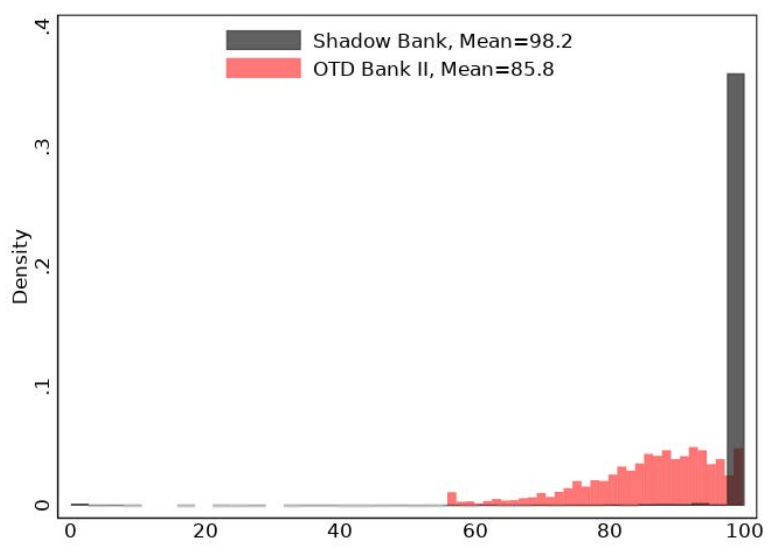

(c) Shadow Bank vs OTD Bank II

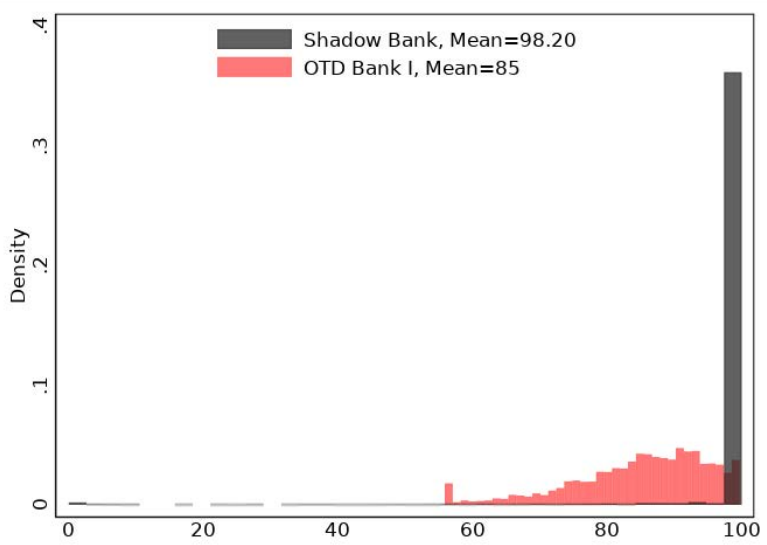

(b) Shadow Bank vs OTD Bank I

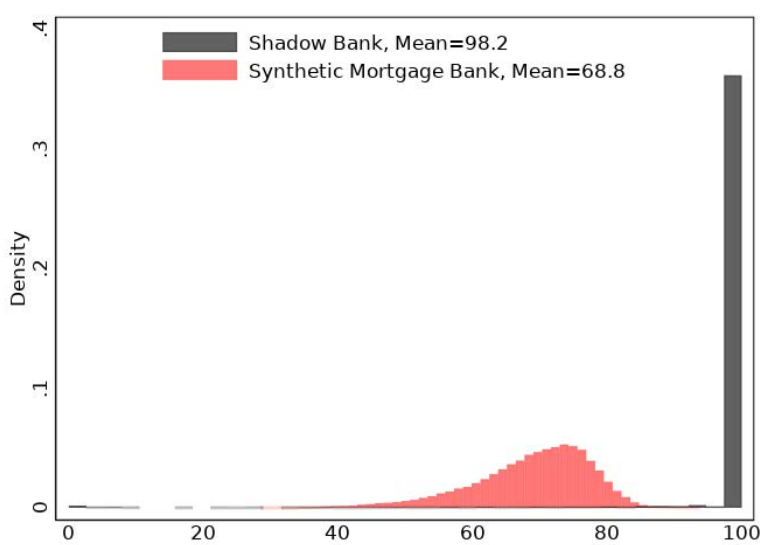

(d) Shadow Bank vs Synthetic Mortgage Bank 


\section{Figure 7: Equity to Asset Ratio and Size - Shadow Banks vs Banks}

This figure plots the equity to asset ratio of shadow banks and banks against the loan volume. Specifically, using a panel data set of quarterly observations from 2011 to 2017, we estimate the following specification for banks and shadow banks, respectively:

$$
\text { Ratio }_{i, t}=\Sigma_{b} \gamma_{b} I\left(\operatorname{Size}_{i, t} \in \text { Bin }_{b}\right)+\epsilon_{i, t}
$$

where Ratio $_{i, t}$ is the equity to asset ratio, $I\left(\operatorname{Size}_{i, t} \in\right.$ Bin $\left._{b}\right)$ is an indicator of whether bank (shadow bank) $i$ 's size falls within size bucket $\operatorname{Bin}_{b}$. The plotted coefficients of interest, $\gamma_{b}$, show how the equity to asset ratio vary nonparametrically across the size distribution, where size is measured by the logarithm of annual mortgage origination volume in dollars. Each size bin covers an incremental value of 0.25 in the size distribution. In other words, the difference between the largest firm's size and the smallest firm's size in each size bin is 0.25 . The shaded area shows the $95 \%$ confidence interval. Standard errors are clustered by institutions. Panel (a) compares shadow banks to all banks, panel (b) shadow banks to OTD banks of version I, panel (c) shadow banks to OTD banks of version II, panel (d) shadow banks to synthetic mortgage banks. The OTD banks of version I are defined as banks whose percentage of mortgages sold in less than 1 year as recorded in HMDA in a given year is in the top five percent among all banks. The average percentage of mortgages sold among OTD banks I is $92.4 \%$, while the minimum percentage of mortgages sold is $85.5 \%$. The average percentage of mortgages sold of shadow banks is $94.4 \%$. In panel (b) we also remove a few shadow banks whose percentage of mortgages sold is less than the OTD bank I threshold of 85.5\%. The OTD banks II are defined as banks whose shares of loans held for sale out of total loans held on balance sheet are greater than $10 \%$ based on their call report data. We note that $10 \%$ share of loans held for sale threshold is broadly consistent with the $85.5 \%$ minimum threshold of mortgages sold out of total originated among OTD banks I (see Section 2 E). The synthetic mortgage bank sample is created by replacing all bank loans with mortgage loans while keeping all the other assets fixed. Data Sources: Shadow banks' quarterly call report filings to state regulators, bank regulatory call report filings, and HMDA.

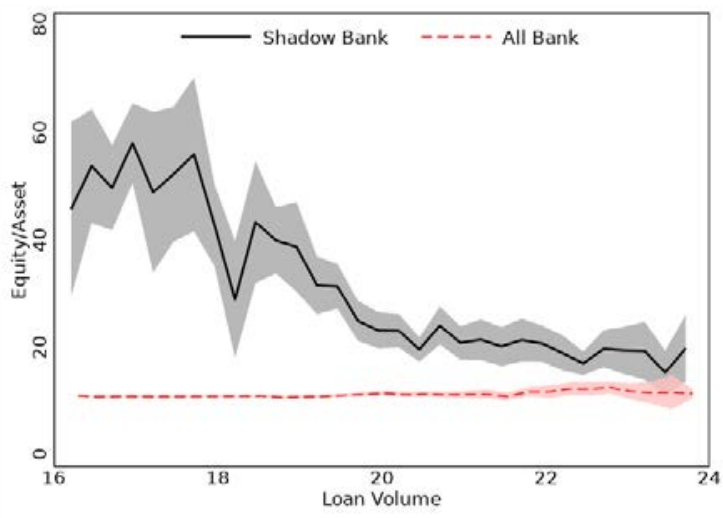

(a) Shadow Bank vs All Bank

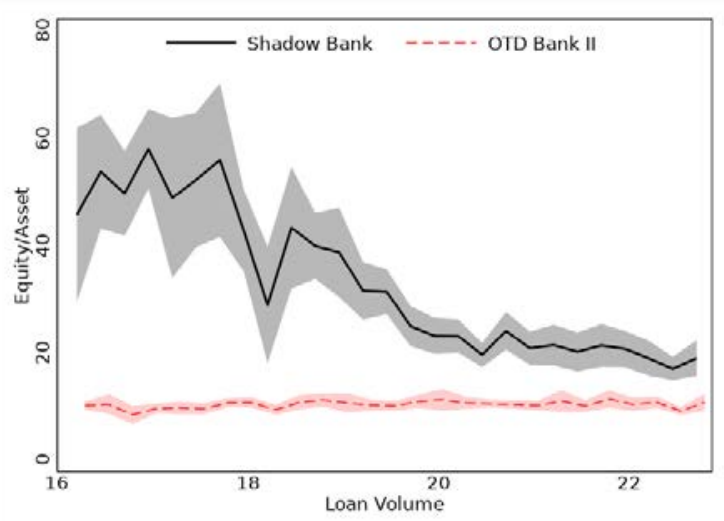

(c) Shadow Bank vs OTD Bank II

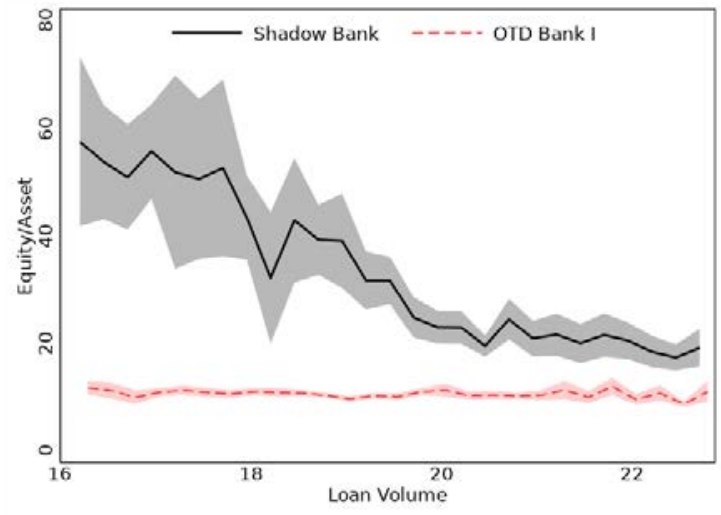

(b) Shadow Bank vs OTD Bank I

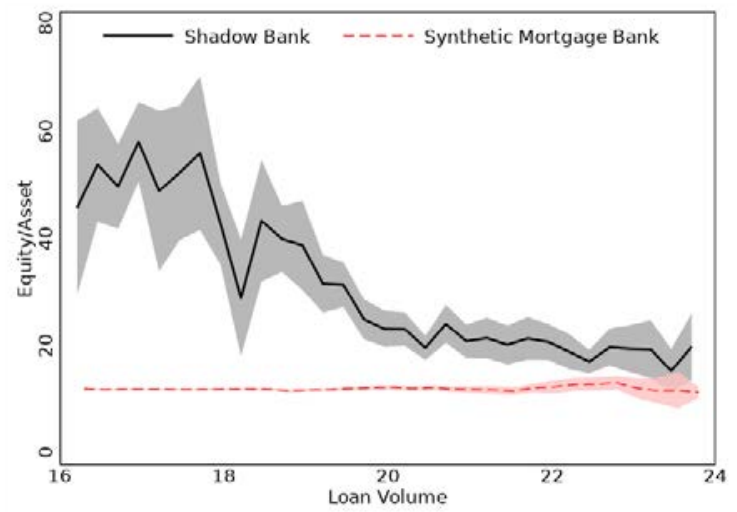

(d) Shadow Bank vs Synthetic Mortgage Bank 


\section{Figure 8: Uninsured and Insured Bank Leverage and Size}

This figure plots uninsured and insured bank debt to asset ratio against loan origination volume. For banks insured debt corresponds to sum of their deposits covered by the FDIC guarantees and uninsured debt is defined as total debt less insured deposits. Specifically, using a panel data set of quarterly observations from 2011 to 2017, we estimate the following specification for banks and shadow banks, respectively:

$$
\text { Ratio }_{i, t}=\Sigma_{b} \gamma_{b} I\left(\text { Size }_{i, t} \in \text { Bin }_{b}\right)+\epsilon_{i, t}
$$

where Ratio $_{i, t}$ is the uninsured and insured bank debt to asset ratio, respectively, $I\left(\operatorname{Size}_{i, t} \in \operatorname{Bin}_{b}\right)$ is an indicator of whether bank $i$ 's size falls within size bucket $\operatorname{Bin}_{b}$. The plotted coefficients of interest, $\gamma_{b}$, show how a given debt to asset ratios vary non-parametrically across the size distribution, where size is measured by the logarithm of annual mortgage origination volume in dollars. Each size bin covers an incremental value of 0.25 in the size distribution. In other words, the difference between the largest firm's size and the smallest firm's size in each size bin is 0.25 . The shaded area shows the $95 \%$ confidence interval. Standard errors are clustered by institutions. Panel (a) shows these results for all banks, panel (b) for OTD banks of version I, panel (c) for OTD banks of version II, panel (d) for synthetic mortgage banks. The OTD banks of version I are defined as banks whose percentage of mortgages sold in less than 1 year as recorded in HMDA in a given year is in the top five percent among all banks. The average percentage of mortgages sold among OTD banks I is $92.4 \%$, while the minimum percentage of mortgages sold is $85.5 \%$. The average percentage of mortgages sold of shadow banks is $94.4 \%$. The OTD banks II are defined as banks whose shares of loans held for sale out of total loans held on balance sheet are greater than $10 \%$ based on their call report data. We note that $10 \%$ share of loans held for sale threshold is broadly consistent with the $85.5 \%$ minimum threshold of mortgages sold out of total originated among OTD banks I (see Section 2E). The synthetic mortgage bank sample is created by replacing all bank loans with mortgage loans while keeping all the other assets fixed. Data Sources: Shadow banks' quarterly call report filings to state regulators, bank regulatory call report filings, and HMDA.

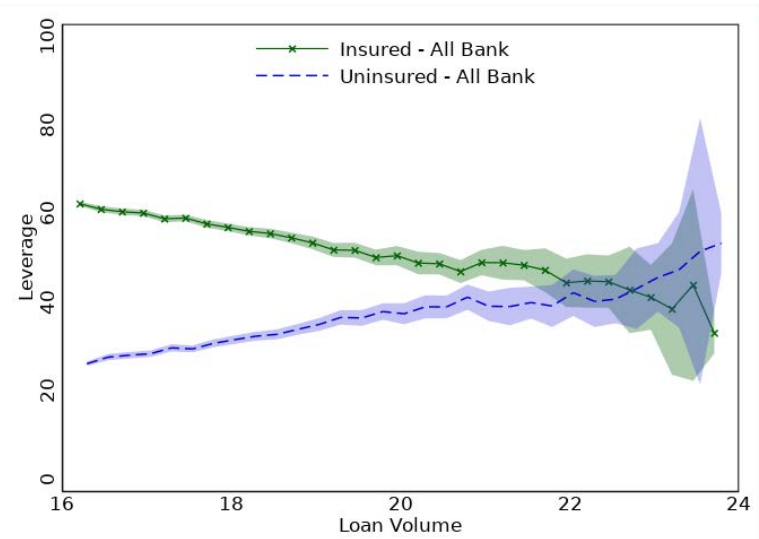

(a) All Bank

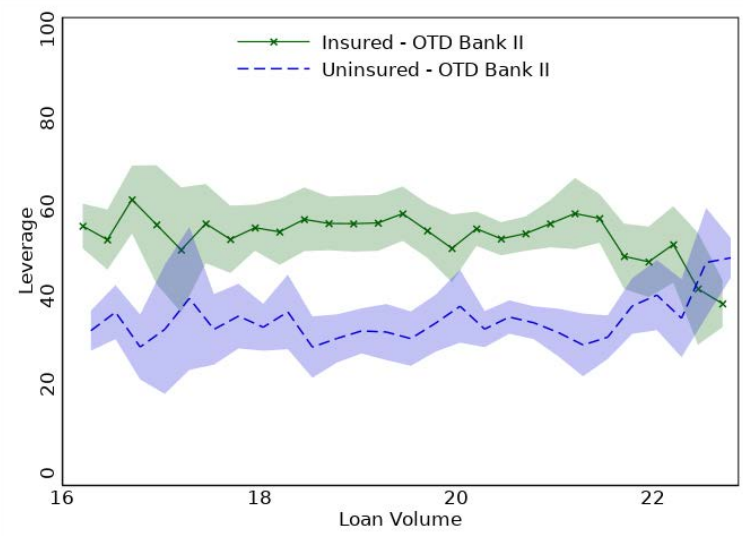

(c) OTD Bank II

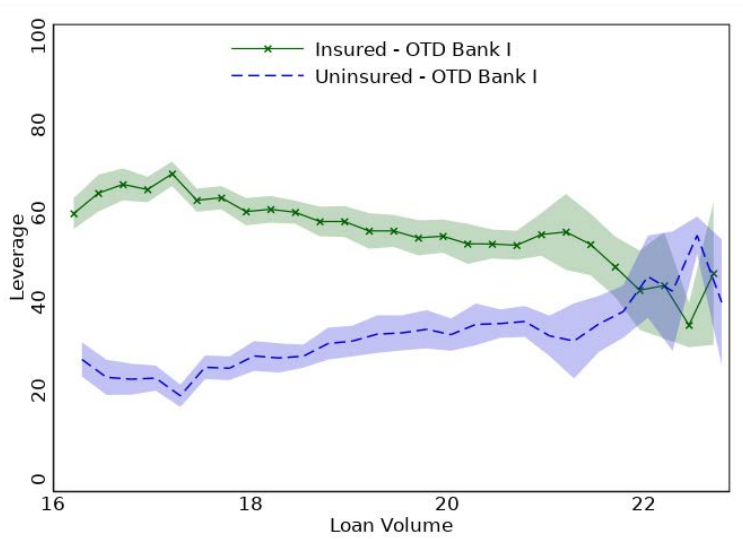

(b) OTD Bank I

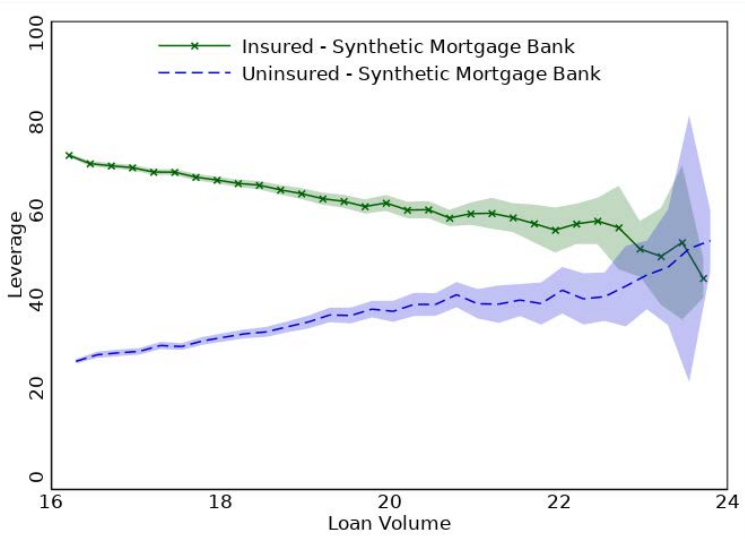

(d) Synthetic Mortgage Bank 


\section{Figure 9: Uninsured Leverage and Size - Shadow Banks vs Banks}

This figure plots uninsured debt to asset ratio against loan origination volume for banks and shadow banks. For banks the uninsured debt is defined as total debt less insured deposits. For shadow banks all debt is uninsured. Specifically, using a panel data set of quarterly observations from 2011 to 2017, we estimate the following specification for banks and shadow banks, respectively:

$$
\text { Ratio }_{i, t}=\Sigma_{b} \gamma_{b} I\left(\text { Size }_{i, t} \in \text { Bin }_{b}\right)+\epsilon_{i, t}
$$

where Ratio $_{i, t}$ is the uninsured and insured bank debt to asset ratio, respectively, $I\left(\operatorname{Size}_{i, t} \in\right.$ Bin $\left._{b}\right)$ is an indicator of whether bank $i$ 's size falls within size bucket $B_{i n}$. The plotted coefficients of interest, $\gamma_{b}$, show how a given debt to asset ratios vary non-parametrically across the size distribution, where size is measured by the logarithm of annual mortgage origination volume in dollars. Each size bin covers an incremental value of 0.25 in the size distribution. In other words, the difference between the largest firm's size and the smallest firm's size in each size bin is 0.25 . The shaded area shows the 95\% confidence interval. Standard errors are clustered by institutions. Panel (a) shows these results for shadow banks and all banks, panel (b) for shadow banks and OTD banks of version I, panel (c) for shadow banks and OTD banks of version II, panel (d) for shadow banks and synthetic mortgage banks. The OTD banks of version I are defined as banks whose percentage of mortgages sold in less than 1 year as recorded in HMDA in a given year is in the top five percent among all banks. The average percentage of mortgages sold among OTD banks I is $92.4 \%$, while the minimum percentage of mortgages sold is $85.5 \%$. The average percentage of mortgages sold of shadow banks is $94.4 \%$. The OTD banks II are defined as banks whose shares of loans held for sale out of total loans held on balance sheet are greater than $10 \%$ based on their call report data. We note that $10 \%$ share of loans held for sale threshold is broadly consistent with the $85.5 \%$ minimum threshold of mortgages sold out of total originated among OTD banks I (see Section 2E). The synthetic mortgage bank sample is created by replacing all bank loans with mortgage loans while keeping all the other assets fixed. Data Sources: Shadow banks' quarterly call report filings to state regulators, bank regulatory call report filings, and HMDA.

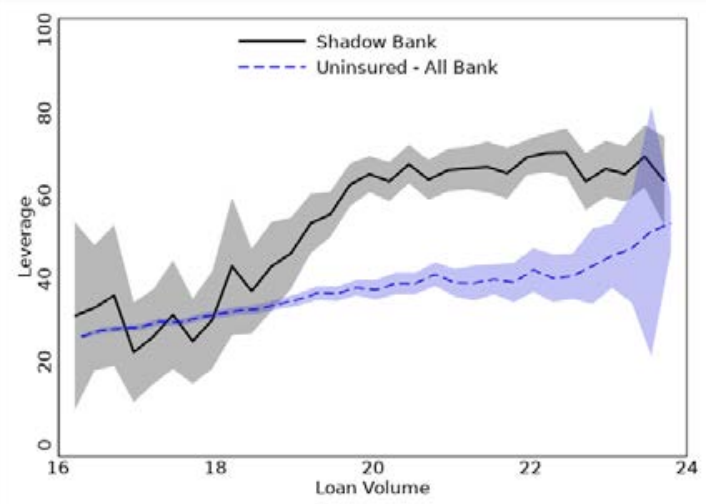

(a) Shadow Banks vs All Bank

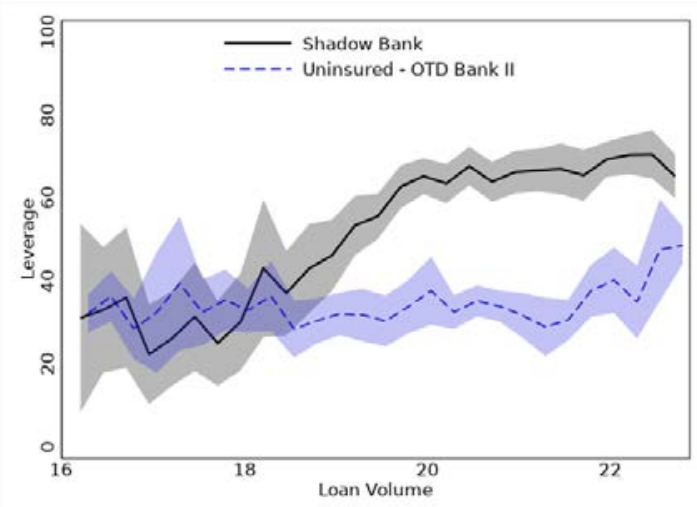

(c) Shadow Bank vs OTD Bank II

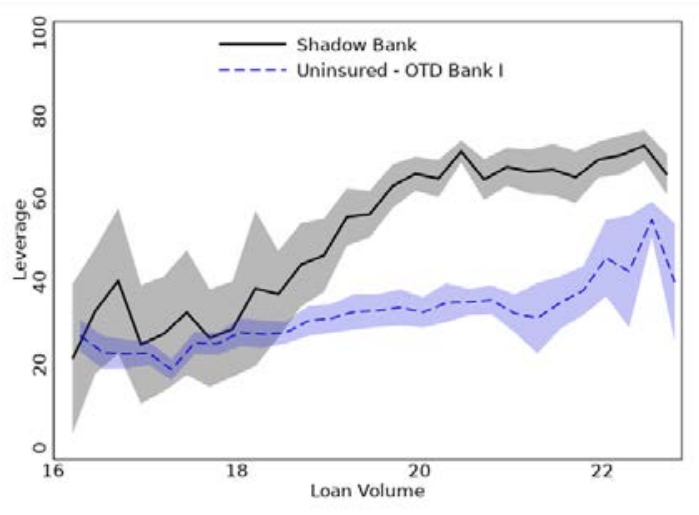

(b) Shadow Bank vs OTD Bank I

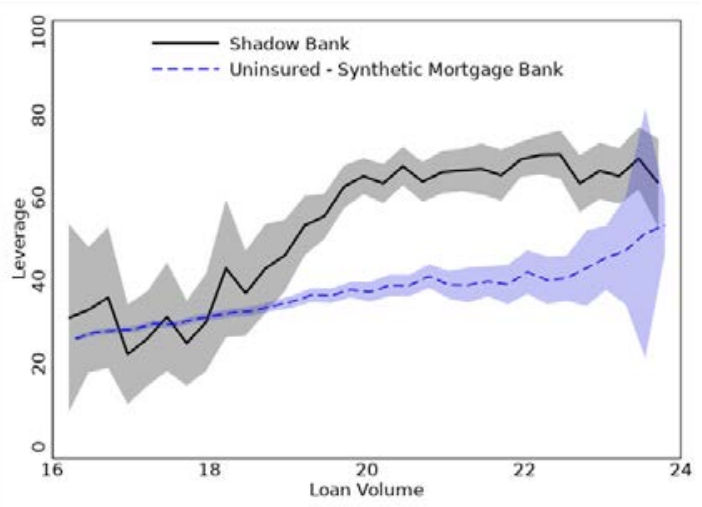

(d) Shadow Bank vs Synthetic Mortgage Bank 


\section{Figure 10: Debt Funding Cost and Size - Shadow Banks vs Banks}

This figure shows average annual interest rate (in \%) on debt against loan origination volume. Panel (a) shows these statistics for shadow banks. We note that all shadow bank debt is uninsured. Panel (b) shows the results for the average annual interest rate for the uninsured and insured bank debt. Panel (c) shows these patterns for annual uninsuredinsured interest rate spread for banks, defined as within bank difference between interest rate on uninsured and insured debt. Specifically, using a panel data set of quarterly observations from 2011 to 2017, we estimate the following specification for banks and shadow banks, respectively:

$$
\text { Ratio }_{i, t}=\Sigma_{b} \gamma_{b} I\left(\text { Size }_{i, t} \in \text { Bin }_{b}\right)+\epsilon_{i, t}
$$

where Ratio $_{i, t}$ is the annual uninsured and insured short-term debt interest rate and the annual uninsured-insured interest rate spread, respectively, $I\left(\right.$ Size $_{i, t} \in$ Bin $\left._{b}\right)$ is an indicator of whether bank (shadow bank) $i$ 's size falls within size bucket $\operatorname{Bin}_{b}$. The plotted coefficients of interest, $\gamma_{b}$, show how these funding ratios vary non-parametrically across the size distribution, where size is measured by the logarithm of annual mortgage origination volume in dollars. Each size bin covers an incremental value of 0.25 in the size distribution. In other words, the difference between the largest firm's size and the smallest firm's size in each size bin is 0.25 . The shaded area shows the $95 \%$ confidence interval. Standard errors are clustered by institutions. Data Sources: Shadow banks' quarterly call report filings to state regulators, bank regulatory call report filings, and HMDA.

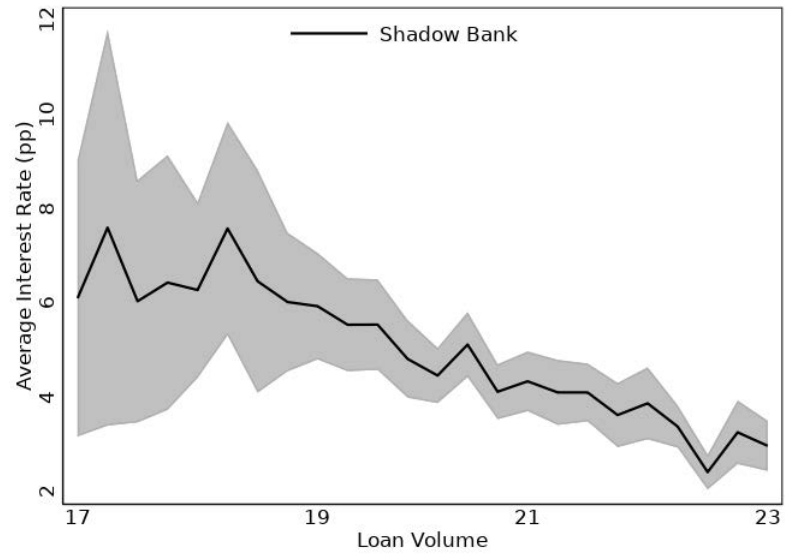

(a) Shadow Bank Short-Term Debt Cost

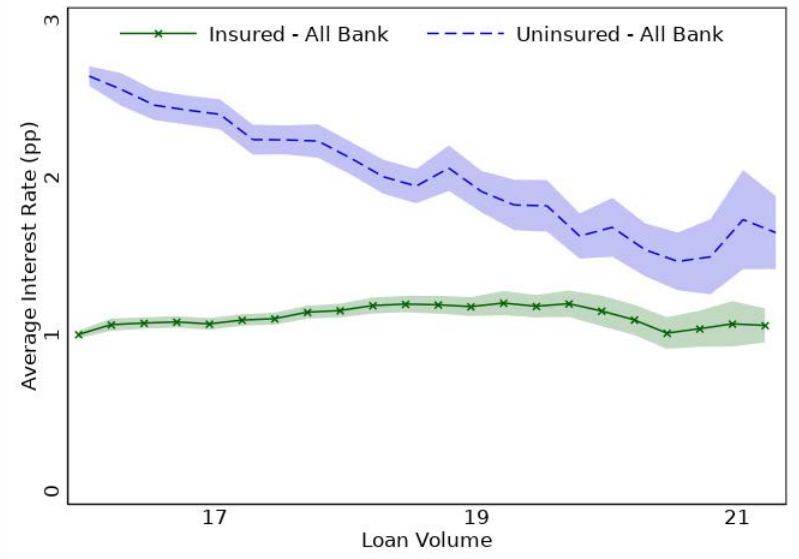

(b) Bank Debt Cost

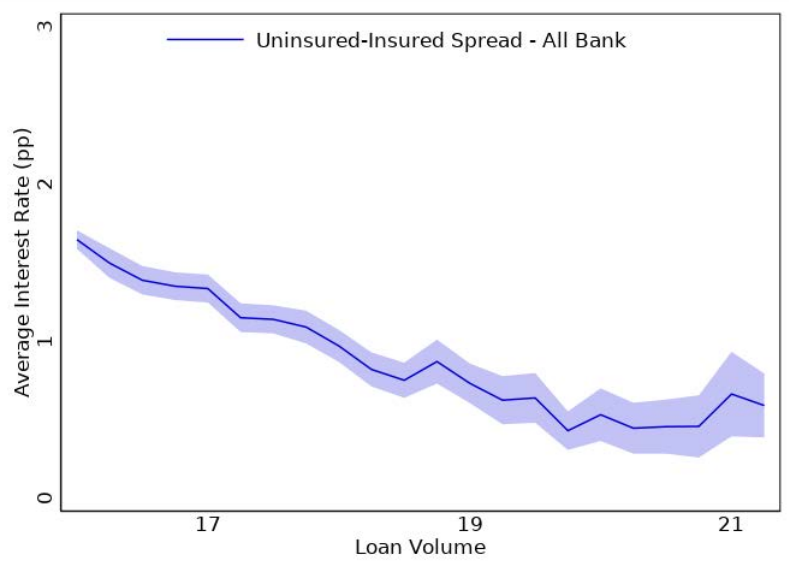

(c) Bank Uninsured-Insured Debt Spread 


\section{Appendix A1: Asset and Loan Characteristics - Shadow Banks vs Banks}

Panel (a) shows comparable categories of asset composition that are consistently reported in the shadow bank and bank call reports. Column (1) of this table reports the mean asset composition of shadow banks active in the US mortgage market in our sample ranging from 2011 Q1 to 2017 Q4 and the banks. We restrict attention to mortgage companies that are required to file HMDA reports and originate mortgage loans. This restriction leaves us with 429 shadow banks that have a license in the two states that provided us data. Column (2) shows these results for all 4,822 banks in our sample, column (3) for 549 OTD banks of version I, and Column (4) for 257 OTD banks of version II. The OTD banks of version I are defined as banks whose percentage of mortgages sold in less than 1 year as recorded in HMDA in a given year is in the top five percent among all banks. The average percentage of mortgages sold among OTD banks I is $92.4 \%$, while the minimum percentage of mortgages sold is $85.5 \%$. The average percentage of mortgages sold of shadow banks is $94.4 \%$. The OTD banks II are defined as banks whose shares of loans held for sale out of total loans held on balance sheet are greater than $10 \%$ based on their call report data. We note that $10 \%$ share of loans held for sale threshold is broadly consistent with the $85.5 \%$ minimum threshold of mortgages sold out of total originated among OTD banks I (see Section 2E). Among shadow banks all reported loans below are real estate loans. Among all bank sample on average $78 \%$ of all loans on balance sheet are real estate loans. Among OTD Banks I about $79 \%$ of loans are real estate loans. Among OTD Banks II about $82 \%$ of loans are real estate loans. Panel (b) shows the fraction of residential loans that are sold for shadow banks and three bank comparison groups based on the 20112017 HMDA data files. Panel (c) visually compares the characteristics of shadow bank and bank loans based on Fannie Mae and Freddie Mac loan acquisition files covering our sample period. Data Sources: Shadow banks' quarterly call report filings to state regulators, bank call reports. HMDA, Fannie Mae and Freddie Mac loan acquisition data.

Panel A: Asset composition as a percentage of total assets - shadow banks vs banks

\begin{tabular}{lcccc}
\hline & Shadow Banks & All Bank & OTD Bank I & OTD Bank II \\
\hline Cash & $11.7 \%$ & $8.5 \%$ & $9.2 \%$ & $8.7 \%$ \\
Securities & $0.3 \%$ & $20.5 \%$ & $16.8 \%$ & $12.6 \%$ \\
Loans & $67.3 \%$ & $65.2 \%$ & $67.2 \%$ & $71.5 \%$ \\
Real Estate Owned & $0.3 \%$ & $0.7 \%$ & $0.8 \%$ & $0.8 \%$ \\
Building and Properties & $2.0 \%$ & $1.9 \%$ & $2.0 \%$ & $1.7 \%$ \\
Good will and Intangible Assets & $0.3 \%$ & $0.5 \%$ & $0.8 \%$ & $1.2 \%$ \\
\hline No. of Institutions & 429 & 4,822 & 549 & 257 \\
\hline \hline
\end{tabular}

Panel B: Residential loan characteristics and a percentage of loans sold - shadow banks vs banks (HMDA)

\begin{tabular}{lcccc}
\hline \hline & Shadow Banks & All Bank & OTD Bank I & OTD Bank II \\
\hline Borrower Income $(\$ \mathrm{~K})$ & 101.6 & 129.9 & 109.8 & 114.9 \\
Loan Amount $(\$ \mathrm{~K})$ & 225.8 & 253.5 & 227.8 & 225.9 \\
Percentage Loans Sold & $93.5 \%$ & $60.9 \%$ & $92.1 \%$ & $88.6 \%$ \\
\hline \hline
\end{tabular}

Panel C: Characteristics of residential loans - shadow banks vs banks (GSE loans)

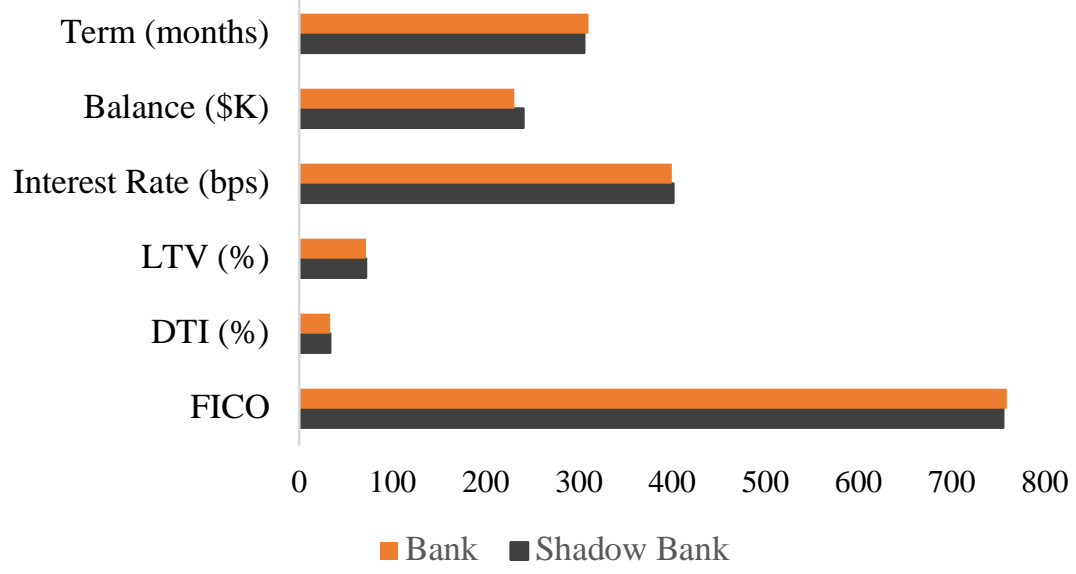




\section{Appendix A2: Percentage of Loans Sold and Loans Held for Sale to Total Loans for Banks}

This figure shows the relation between two empirical measures that we use to construct two variants of OTD banks: the percentage of residential mortgage sold (Percent Sold) based on HMDA data and the ratio of loans held for sale to total loans (based on call reports). The percent sold scale is divided in twenty bins of equal size in terms of number of banks. The OTD banks of version I are defined as banks whose percentage of mortgages sold in less than 1 year as recorded in HMDA in a given year is in the top five percent among all banks (greater than $85.5 \%$ ). As we observe banks that sell more mortgages have on average higher ratio of loans held for sale to total loans (correlation between two measures shown on the figure below equals 0.82). Data Sources: Bank call reports, HMDA.

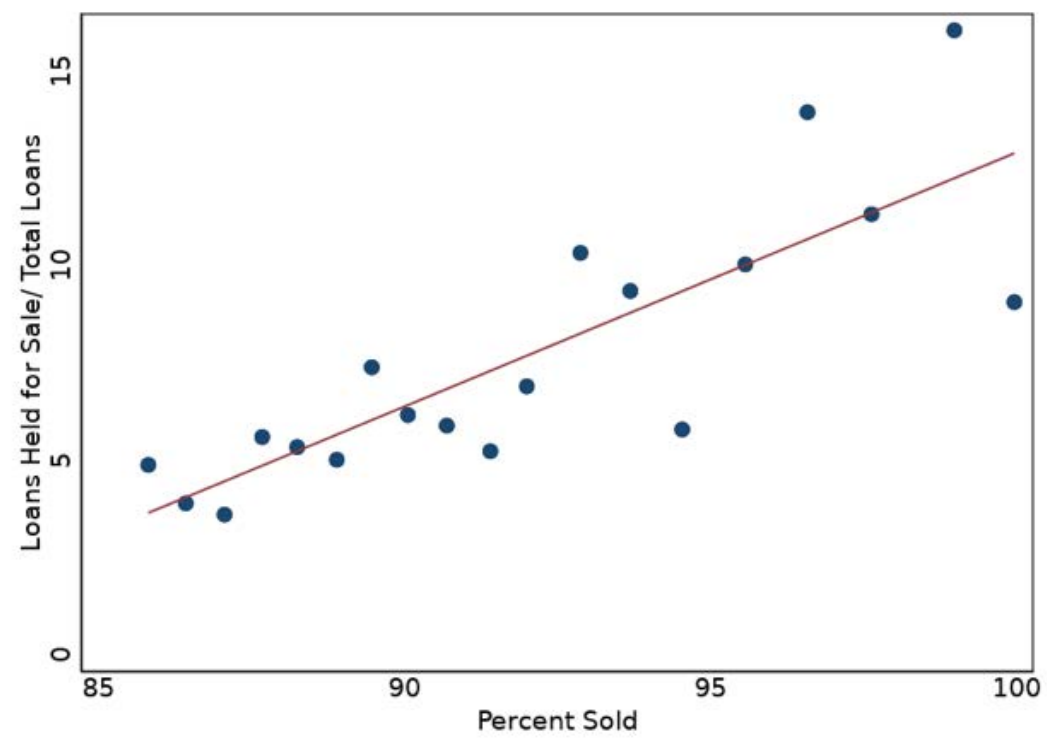




\section{Appendix A3: Equity to Asset Ratio - Lender Fixed Effects}

This figure plots the histograms of the estimated lender fixed effects (FEs) from the equity to asset ratio specification similar to one in Table 4, Column (2) but estimated separately for shadow banks and banks. Panel (a) shows the FEs based on the OLS estimates, while panel (b) shows the estimated FEs after Bayesian shrinkage. Data Sources: Shadow banks' quarterly call report filings to state regulators, bank regulatory call report filing, and HMDA.

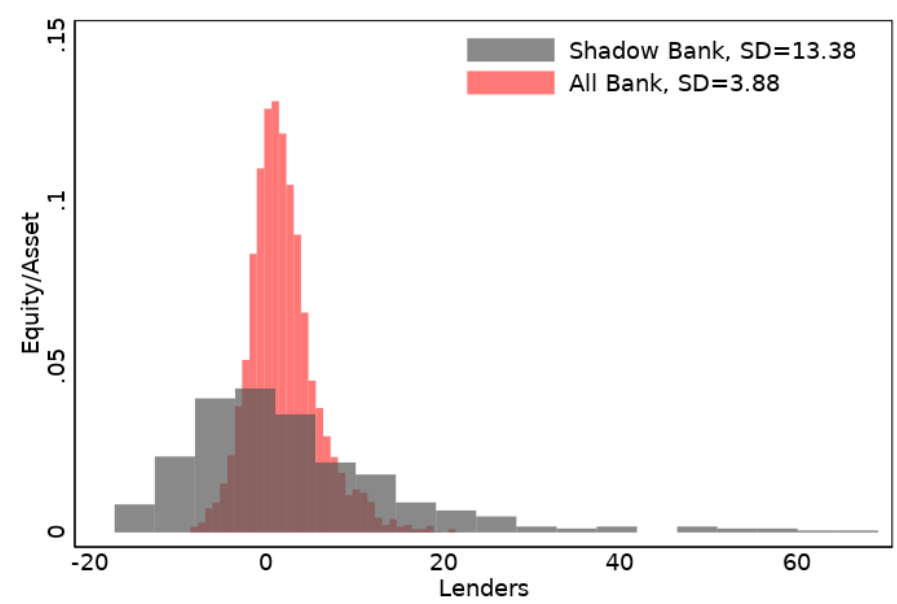

(a) Lender FEs: Shadow Banks vs Banks

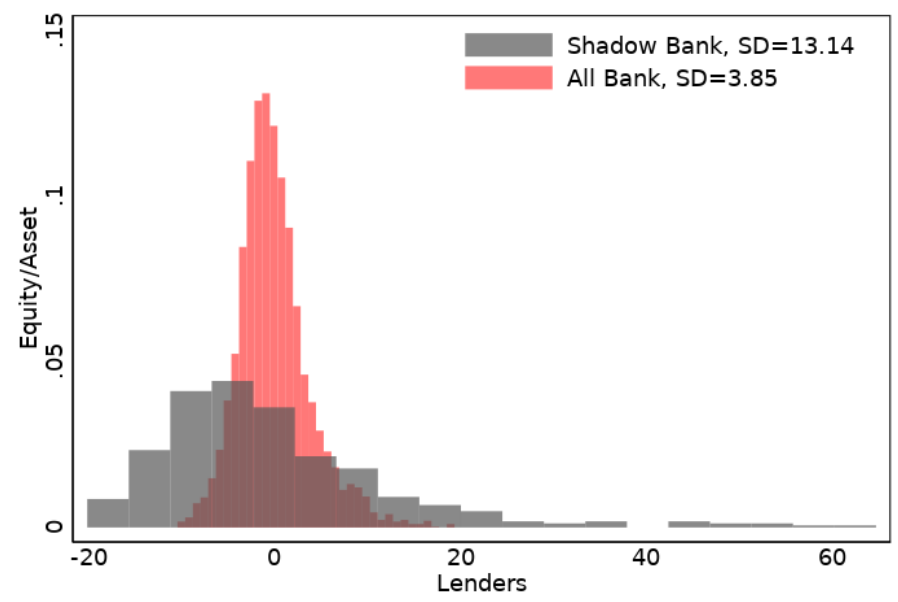

(b) Lender FEs (Shrinkage Estimator): Shadow Banks vs Banks 


\section{Appendix A4: Number of Providers of Warehouse Lines of Credit to Shadow Banks}

This figure plots the histogram (density) of the number of creditors providing the short-term warehouse lines of credit to a given shadow bank. These lines of credit account for most of the shadow banks' debt. Data Sources: Shadow banks' quarterly call report filings.

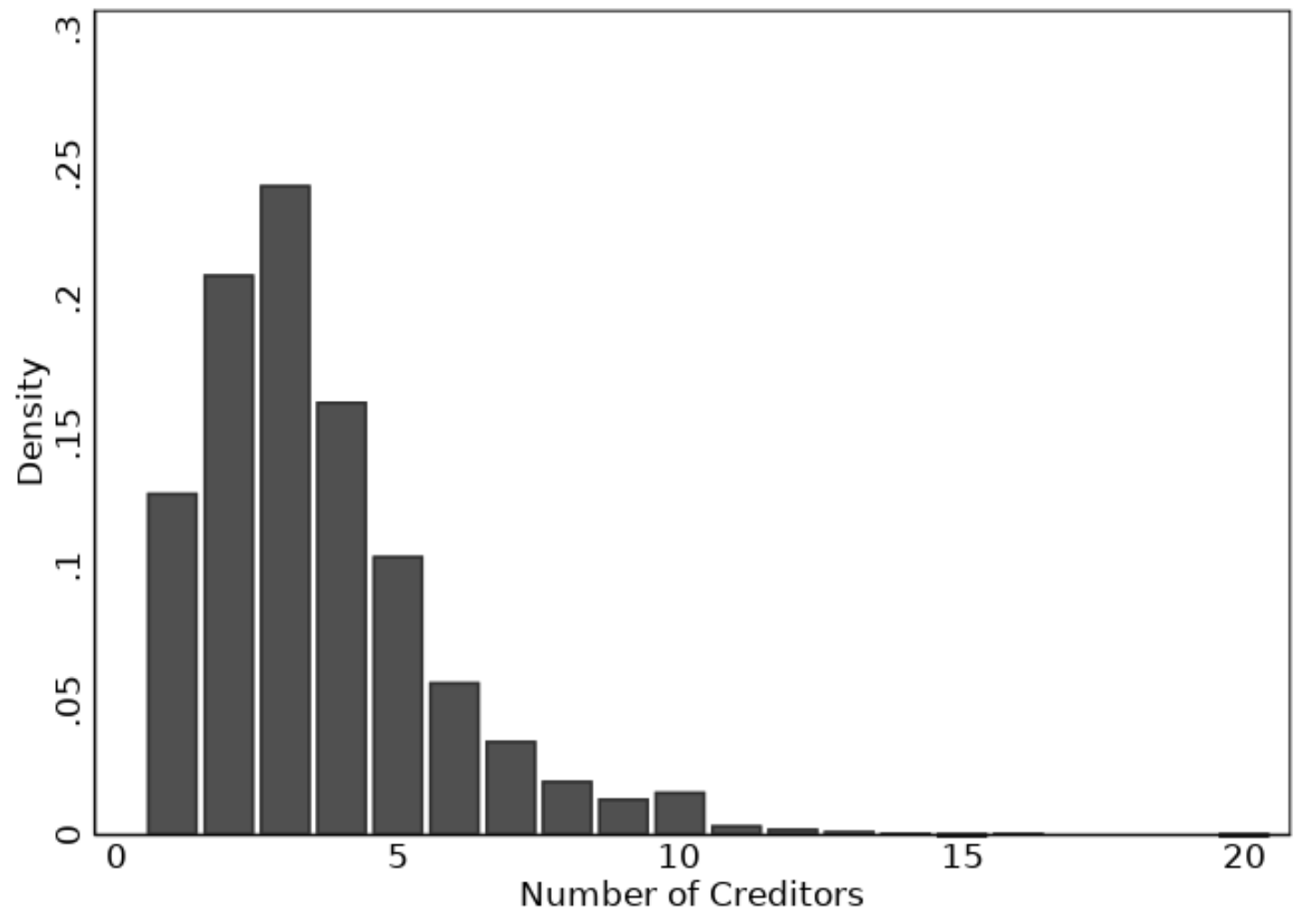




\section{Appendix A5: Tier 1 Capital Ratio and Size - Shadow Banks vs Banks}

This figure plots the risk-based tier 1 capital ratio of shadow banks (lower and upper bound) and risk-based tier 1 capital ratio banks against the loan volume. Specifically, using a panel data set of quarterly observations from 2011 to 2017, we estimate the following specification for banks and shadow banks, respectively:

$$
\text { Ratio }_{i, t}=\Sigma_{b} \gamma_{b} I\left(\text { Size }_{i, t} \in \text { Bin }_{b}\right)+\epsilon_{i, t}
$$

where Ratio $_{i, t}$ is the tier 1 capital ratio ratio, $I\left(\right.$ Size $_{i, t} \in$ Bin $_{b}$ ) is an indicator of whether bank (shadow bank) $i$ 's size falls within size bucket $B i n_{b}$. The plotted coefficients of interest, $\gamma_{b}$, show how the funding ratio vary nonparametrically across the size distribution, where size is measured by the logarithm of annual mortgage origination volume in dollars. Each size bin covers an incremental value of 0.25 in the size distribution. In other words, the difference between the largest firm's size and the smallest firm's size in each size bin is 0.25 . The shaded area shows the 95\% confidence interval. Standard errors are clustered by institutions. Panel (a) compares shadow banks to all banks, panel (b) shadow banks to OTD banks of version I, panel (c) shadow banks to OTD banks of version II, panel (d) shadow banks to synthetic mortgage banks. The OTD banks of version I are defined as banks whose percentage of mortgages sold in less than 1 year as recorded in HMDA in a given year is in the top five percent among all banks. The average percentage of mortgages sold among OTD banks I is $92.4 \%$, while the minimum percentage of mortgages sold is $85.5 \%$. The average percentage of mortgages sold of shadow banks is $94.4 \%$. In panel (b) we also remove a few shadow banks whose percentage of mortgages sold is less than the OTD bank I threshold of $85.5 \%$. The OTD banks II are defined as banks whose shares of loans held for sale out of total loans held on balance sheet are greater than $10 \%$ based on their call report data. We note that $10 \%$ share of loans held for sale threshold is broadly consistent with the $85.5 \%$ minimum threshold of mortgages sold out of total originated among OTD banks I (see Section 2E). The synthetic mortgage bank sample is created by replacing all bank loans with mortgage loans while keeping all the other assets fixed. Data Sources: Shadow banks' quarterly call report filings to state regulators, bank regulatory call report filings, and HMDA.

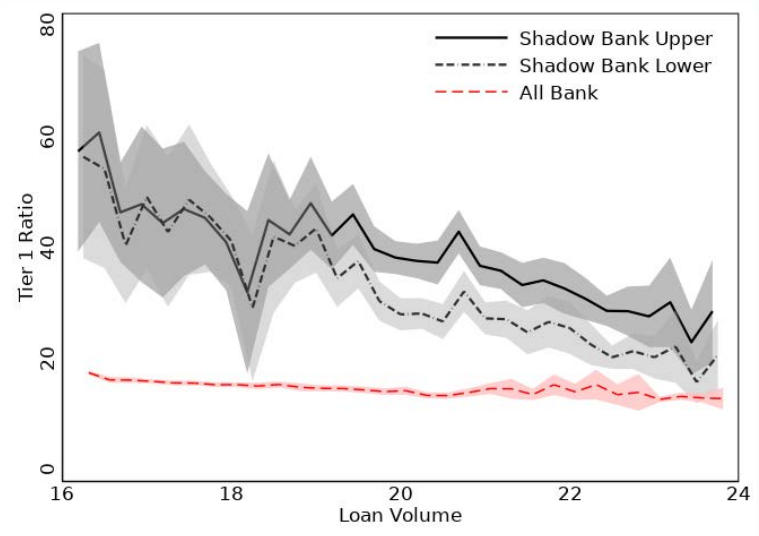

(a) All Bank

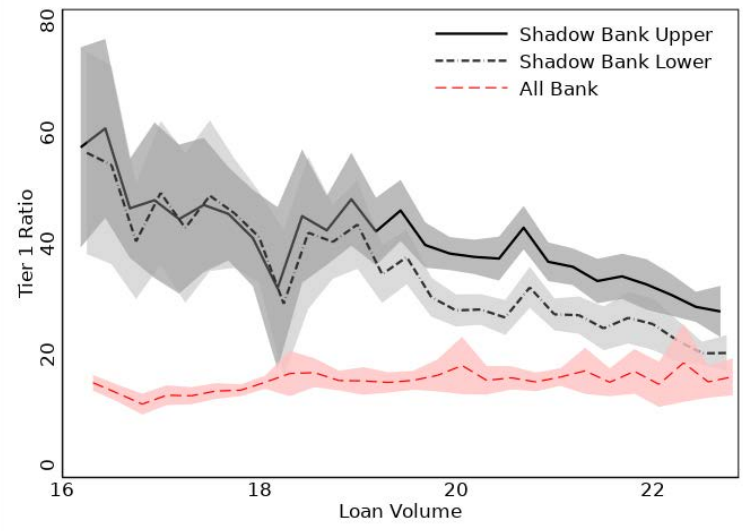

(c) OTD Bank II

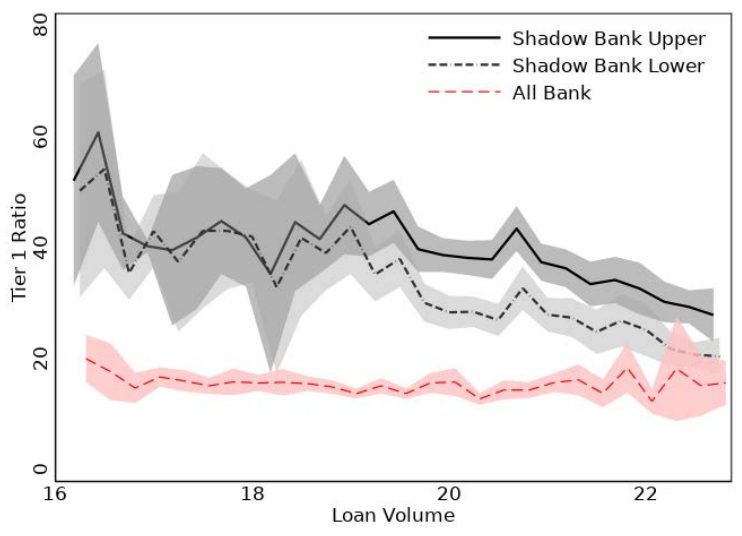

(b) OTD Bank I

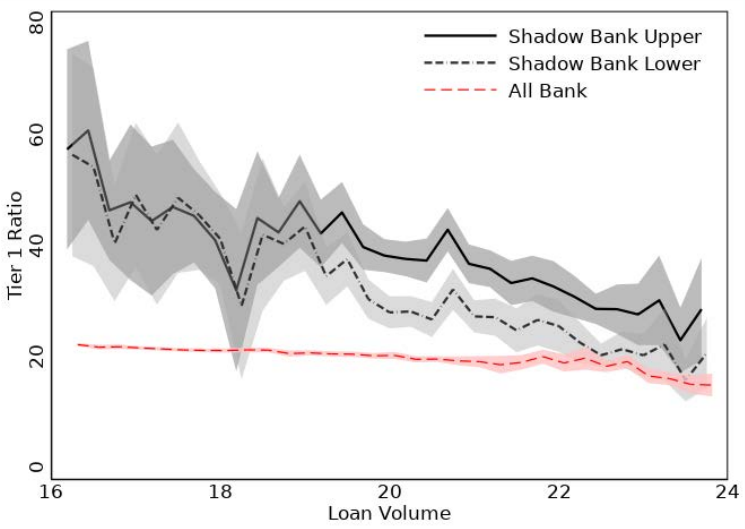

(d) Synthetic Mortgage Bank 


\section{Appendix A6: Loan Volume and Assets - Shadow Banks and Banks}

This figure plots relation between our two size measures for financial institutions: loan volume (logarithm of annual loan origination volume in dollars) and assets (logarithm of assets in dollars). Panel (a) shows the results for shadow banks while panel (b) shows the results for banks. The loan volume scale is divided in twenty bins of equal size in terms of number of institutions. The correlation of loan volume with size shown on the figures below equals 0.90 for shadow banks and 0.96 for banks.

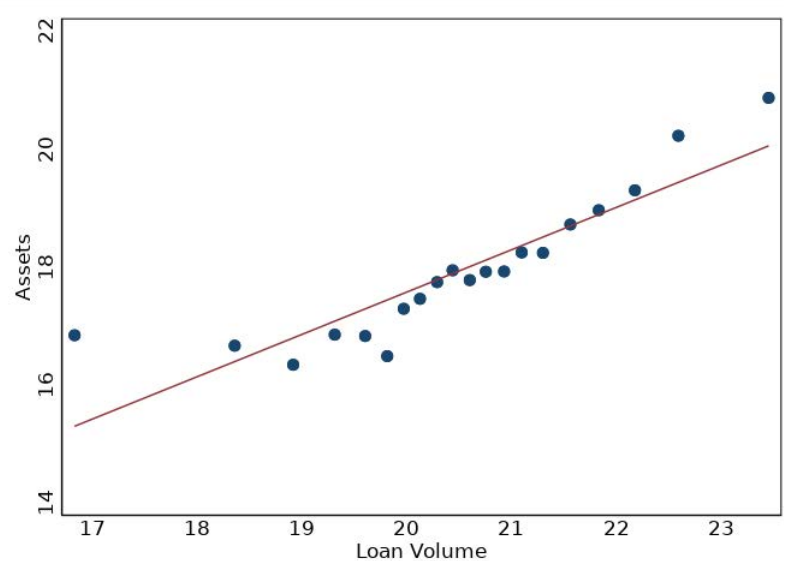

(a) Shadow banks

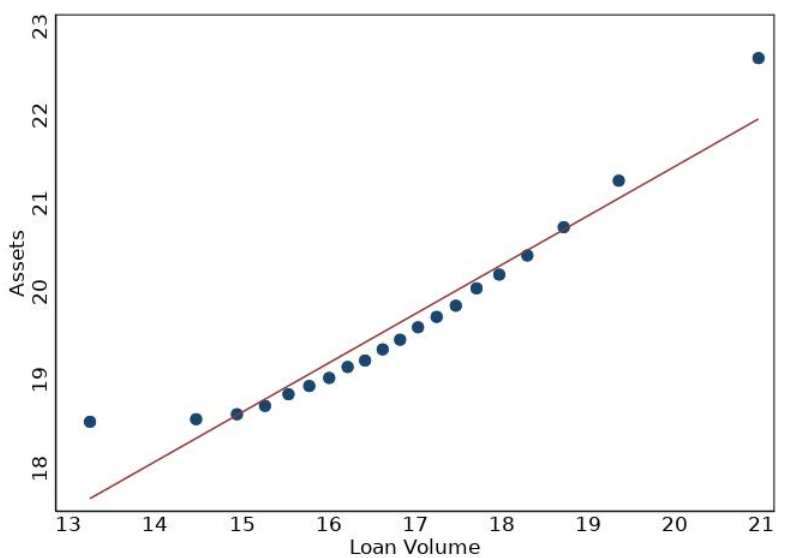

(b) Banks 


\section{Appendix A7: Equity to Asset Ratio and Size (Assets) - Shadow Banks vs Banks}

This figure plots the equity to asset ratio of shadow banks and banks against the lender's assets. Specifically, using a panel data set of quarterly observations from 2011 to 2017, we estimate the following specification for banks and shadow banks, respectively:

$$
\text { Ratio }_{i, t}=\Sigma_{b} \gamma_{b} I\left(\operatorname{Size}_{i, t} \in \text { Bin }_{b}\right)+\epsilon_{i, t}
$$

where Ratio $_{i, t}$ is the equity to asset ratio, $I\left(\operatorname{Size}_{i, t} \in \operatorname{Bin}_{b}\right)$ is an indicator of whether bank (shadow bank) $i$ 's size falls within size bucket $B i n_{b}$. The plotted coefficients of interest, $\gamma_{b}$, show how the equity to asset ratio vary nonparametrically across the size distribution, where size is measured by the logarithm of assets in dollars. Each size bin covers an incremental value of 0.25 in the size distribution. In other words, the difference between the largest firm's size and the smallest firm's size in each size bin is 0.25 . The shaded area shows the $95 \%$ confidence interval. Standard errors are clustered by institutions. Panel (a) compares shadow banks to all banks, panel (b) shadow banks to OTD banks of version I, panel (c) shadow banks to OTD banks of version II, panel (d) shadow banks to synthetic mortgage banks. The OTD banks of version I are defined as banks whose percentage of mortgages sold in less than 1 year as recorded in HMDA in a given year is in the top five percent among all banks. The average percentage of mortgages sold among OTD banks I is $92.4 \%$, while the minimum percentage of mortgages sold is $85.5 \%$. The average percentage of mortgages sold of shadow banks is $94.4 \%$. In panel (b) we also remove a few shadow banks whose percentage of mortgages sold is less than the OTD bank I threshold of $85.5 \%$. The OTD banks II are defined as banks whose shares of loans held for sale out of total loans held on balance sheet are greater than $10 \%$ based on their call report data. We note that $10 \%$ share of loans held for sale threshold is broadly consistent with the $85.5 \%$ minimum threshold of mortgages sold out of total originated among OTD banks I (see Section 2E). The synthetic mortgage bank sample is created by replacing all bank loans with mortgage loans while keeping all the other assets fixed. Data Sources: Shadow banks' quarterly call report filings to state regulators, bank regulatory call report filings, and HMDA.

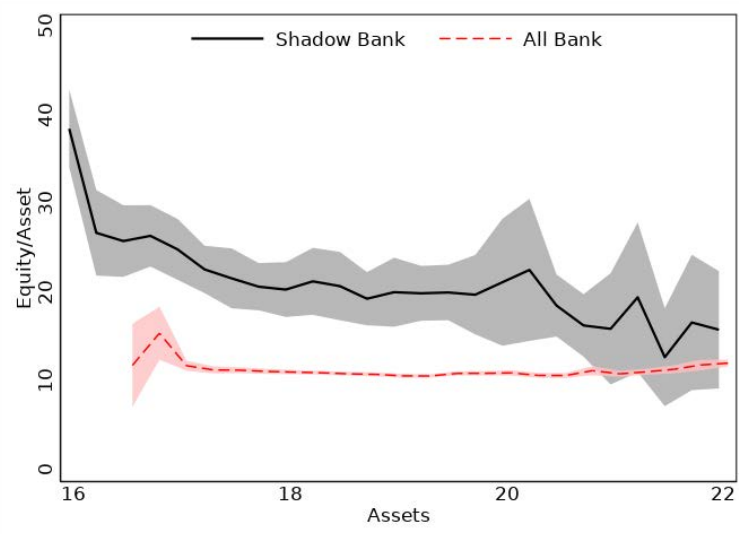

(a) Shadow Bank vs All Bank

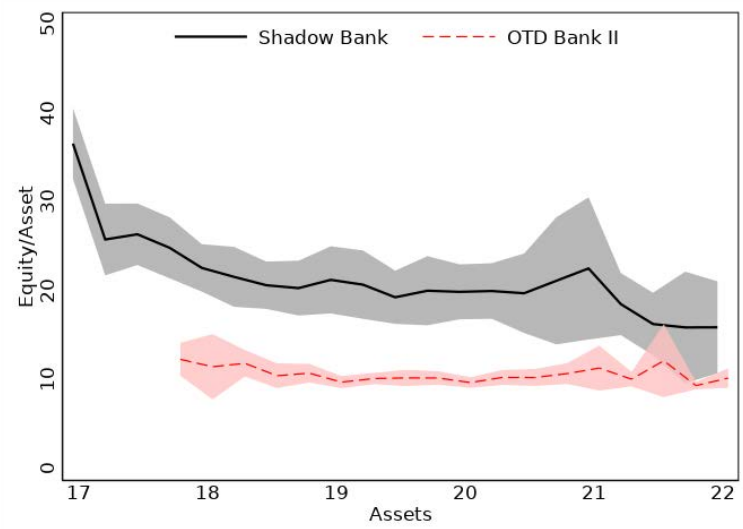

(c) Shadow Bank vs OTD Bank II

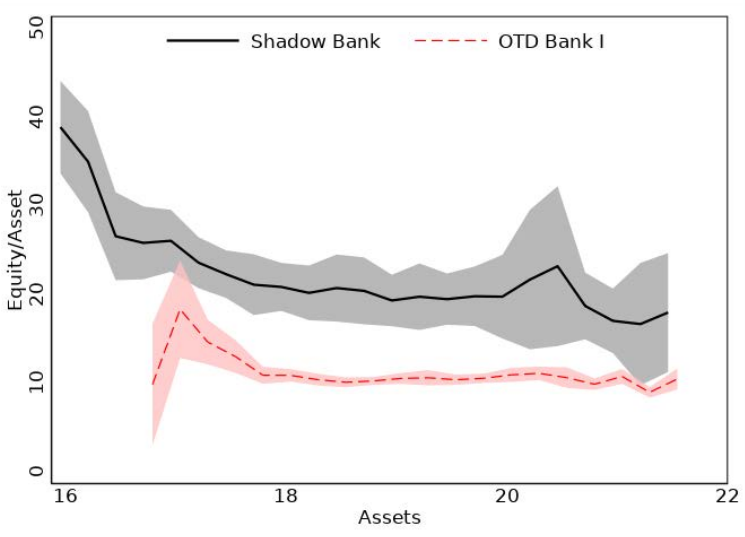

(b) Shadow Bank vs OTD Bank I

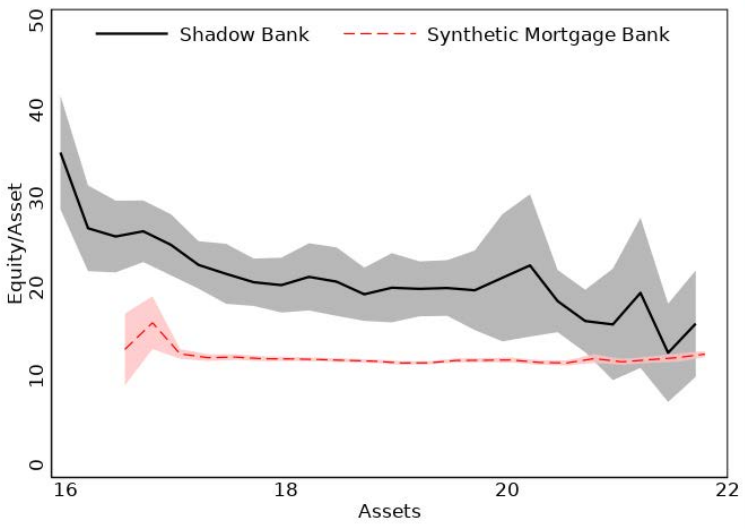

(d) Shadow Bank vs Synthetic Mortgage Bank 


\section{Appendix A8: Tier 1 Capital Ratio and Size (Assets) - Shadow Banks vs Banks}

This figure plots the risk-based tier 1 capital ratio of shadow banks (lower and upper bound) and risk-based tier 1 capital ratio banks against the assets. Specifically, using a panel data set of quarterly observations from 2011 to 2017 , we estimate the following specification for banks and shadow banks, respectively:

$$
\text { Ratio }_{i, t}=\Sigma_{b} \gamma_{b} I\left(\text { Size }_{i, t} \in \text { Bin }_{b}\right)+\epsilon_{i, t}
$$

where Ratio $_{i, t}$ is the tier 1 capital ratio ratio, $I\left(\operatorname{Size}_{i, t} \in B_{i n_{b}}\right)$ is an indicator of whether bank (shadow bank) $i$ 's size falls within size bucket Bin $_{b}$. The plotted coefficients of interest, $\gamma_{b}$, show how the funding ratio vary nonparametrically across the size distribution, where size is measured by the logarithm of assets in dollars. Each size bin covers an incremental value of 0.25 in the size distribution. In other words, the difference between the largest firm's size and the smallest firm's size in each size bin is 0.25 . The shaded area shows the $95 \%$ confidence interval. Standard errors are clustered by institutions. Panel (a) compares shadow banks to all banks, panel (b) shadow banks to OTD banks of version I, panel (c) shadow banks to OTD banks of version II, panel (d) shadow banks to synthetic mortgage banks. The OTD banks of version I are defined as banks whose percentage of mortgages sold in less than 1 year as recorded in HMDA in a given year is in the top five percent among all banks. The average percentage of mortgages sold among OTD banks $\mathrm{I}$ is $92.4 \%$, while the minimum percentage of mortgages sold is $85.5 \%$. The average percentage of mortgages sold of shadow banks is $94.4 \%$. In panel (b) we also remove a few shadow banks whose percentage of mortgages sold is less than the OTD bank I threshold of 85.5\%. The OTD banks II are defined as banks whose shares of loans held for sale out of total loans held on balance sheet are greater than $10 \%$ based on their call report data. We note that $10 \%$ share of loans held for sale threshold is broadly consistent with the $85.5 \%$ minimum threshold of mortgages sold out of total originated among OTD banks I (see Section 2E). The synthetic mortgage bank sample is created by replacing all bank loans with mortgage loans while keeping all the other assets fixed. Data Sources: Shadow banks' quarterly call report filings to state regulators, bank regulatory call report filings, and HMDA.

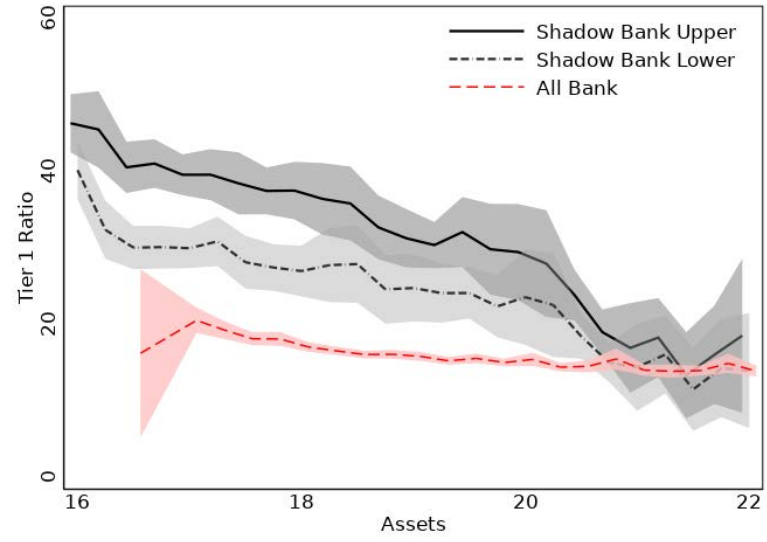

(a) All Bank

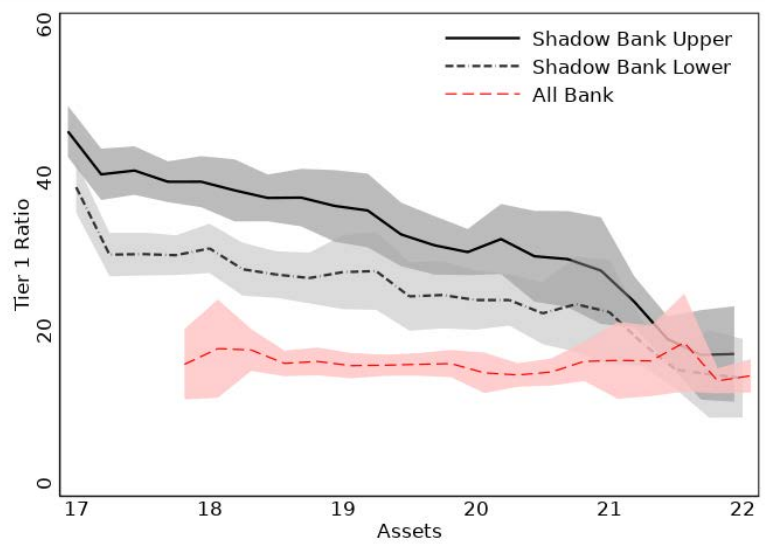

(c) OTD Bank II

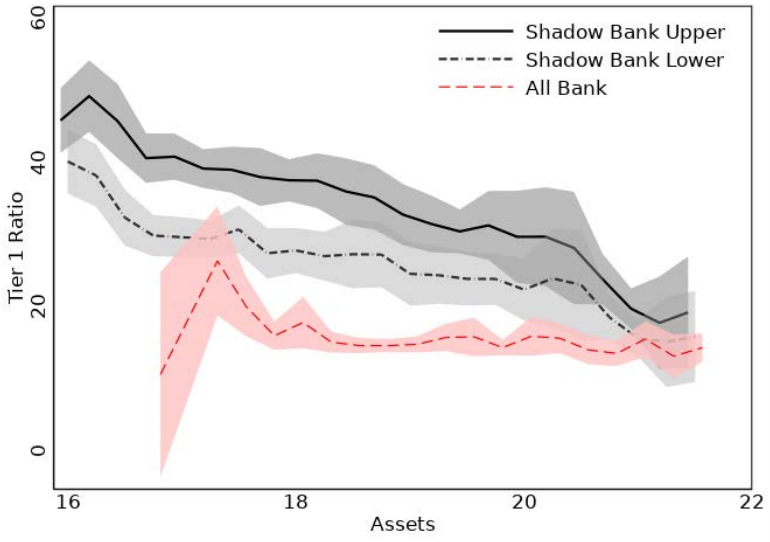

(b) OTD Bank I

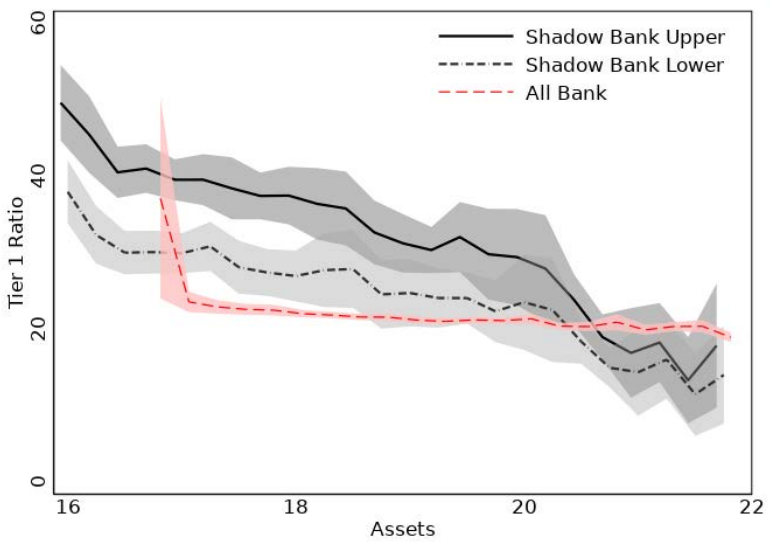

(d) Synthetic Mortgage Bank 


\section{Appendix A9: Tier 1 Capital Ratio and Size - Shadow Banks vs Banks}

This table reports results of OLS regression of the risk-based tier 1 capital ratio on shadow bank indicator, and its interaction with size. The size is measured by the logarithm of annual mortgage origination volume in dollars (Loan Volume). The sample consists of shadow banks and all banks (Column 1), shadow banks and OTD banks of version I (Column 2), shadow banks and OTD banks of version II (Column 3), shadow banks and synthetic mortgage banks which are constructed by replacing all bank assets with residential mortgages (Column 4). Since shadow banks do not report risk-based tier 1 capital ratios, we compute this ratio by applying the Basel III risk-based tier 1 capital ratio formula. Since we do not observe the detailed risk profiles for each type of assets held on the shadow banks' balance sheet, we use the upper bound and lower bound of shadow banks' tier 1 capital ratios in panel (a) and (b), respectively. These bounds are computed as described in Section 2.D. The OTD banks of version I are defined as banks whose percentage of mortgages sold in less than 1 year as recorded in HMDA in a given year is in the top five percent among all banks. The average percentage of mortgages sold among OTD banks I is $92.4 \%$, while the minimum percentage of mortgages sold is $85.5 \%$. The average percentage of mortgages sold of shadow banks is 94.4\%. In column (2) we also remove a few shadow banks whose percentage of mortgages sold is less than the OTD bank I threshold of $85.5 \%$. The OTD banks II are defined as banks whose shares of loans held for sale out of total loans held on balance sheet are greater than $10 \%$ based on their call report data. We note that $10 \%$ share of loans held for sale threshold is broadly consistent with the $85.5 \%$ minimum threshold of mortgages sold out of total originated among OTD banks I (see Section 2E). The synthetic mortgage bank sample is created by replacing all bank loans with mortgage loans while keeping all the other assets fixed. The year-quarter time fixed effects (Date $F E)$ are included in all specifications. Institution controls include the asset growth, the share of refinanced mortgages out of total mortgage origination volume, the share of government-insured mortgages out of total mortgage origination volume, the logarithm of annual mortgage origination volume in dollars, the geographic loan dispersion, and the logarithm of the weighted average of income per capita in states of operation, where each state income per capita is weighted by the share of institution $i$ 's loan origination in this state out of total loan origination of institution $i$, as reported in HMDA. The estimated coefficient of the interaction term of shadow bank indicator with loan volume is scaled by one standard deviation of loan volume. Standard errors in the parentheses are clustered by institution. Data Sources: Shadow banks' quarterly call report filings to state regulators, bank regulatory call report filings, and HMDA.

Panel A: Tier 1 capital ratio (upper bound)

\begin{tabular}{lcccc}
\hline \hline & $\begin{array}{c}\text { Shadow Bank vs } \\
\text { All Bank }\end{array}$ & $\begin{array}{c}\text { Shadow Bank vs } \\
\text { OTD Bank I }\end{array}$ & $\begin{array}{c}\text { Shadow Bank vs } \\
\text { OTD Bank II }\end{array}$ & $\begin{array}{c}\text { Shadow Bank vs } \\
\text { Synthetic } \\
\text { Mortgage Bank }\end{array}$ \\
\cline { 2 - 5 } & $(1)$ & $(2)$ & $(3)$ & $(4)$ \\
Shadow Bank & 85.28 & 86.92 & 107.68 & 82.78 \\
Shadow Bank $\times$ Loan Volume & $(12.11)$ & $(13.43)$ & $(12.38)$ & $(12.12)$ \\
\hline Date FE & -5.81 & -6.01 & -8.21 & -6.18 \\
Institution Controls & $(1.14)$ & $(1.28)$ & $(1.18)$ & $(1.14)$ \\
Observations & Yes & Yes & Yes & Yes \\
R2 & Yes & Yes & Yes & Yes \\
Y-Variable Mean & 109,411 & 10,947 & 8,401 & 109,411 \\
\multicolumn{1}{c}{ Shadow Banks } & 0.291 & 0.408 & 0.311 & 0.238 \\
\multicolumn{1}{c}{ Banks } & 17.33 & 27.18 & 31.59 & 22.37 \\
\hline \hline
\end{tabular}




\section{Appendix A9: Tier 1 Capital Ratio and Size - Shadow Banks vs Banks [continued]}

Panel B: Tier 1 capital ratio (lower bound)

\begin{tabular}{lcccc}
\hline \hline & $\begin{array}{c}\text { Shadow Bank vs } \\
\text { All Bank }\end{array}$ & $\begin{array}{c}\text { Shadow Bank vs } \\
\text { OTD Bank I }\end{array}$ & $\begin{array}{c}\text { Shadow Bank vs } \\
\text { OTD Bank II }\end{array}$ & $\begin{array}{c}\text { Shadow Bank vs } \\
\text { Synthetic } \\
\text { Mortgage Bank }\end{array}$ \\
\cline { 2 - 5 } & $(1)$ & $(2)$ & $(3)$ & $(4)$ \\
\cline { 2 - 5 } Shadow Bank & 69.47 & 61.27 & 80.60 & 66.97 \\
Shadow Bank $\times$ Loan Volume & $(11.27)$ & $(12.14)$ & $(11.84)$ & $(11.28)$ \\
\hline Date FE & -5.33 & -4.59 & -6.62 & -5.70 \\
Institution Controls & $(1.05)$ & $(1.15)$ & $(1.11)$ & $(1.05)$ \\
Observations & Yes & Yes & Yes & Yes \\
R2 & Yes & Yes & Yes & Yes \\
Y-Variable Mean & 109,411 & 10,947 & 8,401 & 109,411 \\
$\quad$ Shadow Banks & 0.143 & 0.250 & 0.208 & 0.086 \\
Banks & 16.77 & 21.85 & 24.20 & 21.80 \\
\hline \hline
\end{tabular}




\section{Appendix A10: Equity to Asset Ratio and Size (Assets) - Shadow Banks vs Banks}

This table reports results of OLS regression of equity to asset ratio on shadow bank indicator, and its interaction with size. The size is measured by the logarithm of assets in dollars (Assets). The sample consists of shadow banks and all banks (Column 1), shadow banks and OTD banks of version I (Column 2), shadow banks and OTD banks of version II (Column 3), shadow banks and synthetic mortgage banks which are constructed by replacing all bank assets with residential mortgages (Column 4). The OTD banks of version I are defined as banks whose percentage of mortgages sold in less than 1 year as recorded in HMDA in a given year is in the top five percent among all banks. The average percentage of mortgages sold among OTD banks I is $92.4 \%$, while the minimum percentage of mortgages sold is $85.5 \%$. The average percentage of mortgages sold of shadow banks is $94.4 \%$. In column (2) we also remove a few shadow banks whose percentage of mortgages sold is less than the OTD bank I threshold of $85.5 \%$. The OTD banks II are defined as banks whose shares of loans held for sale out of total loans held on balance sheet are greater than $10 \%$ based on their call report data. We note that $10 \%$ share of loans held for sale threshold is broadly consistent with the $85.5 \%$ minimum threshold of mortgages sold out of total originated among OTD banks I (see Section 2E). The synthetic mortgage bank sample is created by replacing all bank loans with mortgage loans while keeping all the other assets fixed. The year-quarter time fixed effects (Date $F E$ ) are included in all specifications. Institution controls include the asset growth, the share of refinanced mortgages out of total mortgage origination volume, the share of government-insured mortgages out of total mortgage origination volume, the logarithm of assets in dollars, the geographic loan dispersion, and the logarithm of the weighted average of income per capita in states of operation, where each state income per capita is weighted by the share of institution $i$ 's loan origination in this state out of total loan origination of institution $i$, as reported in HMDA. The estimated coefficient of the interaction term of shadow bank indicator with assets is scaled by one standard deviation of assets. Standard errors in the parentheses are clustered by institution. Data Sources: Shadow banks' quarterly call report filings to state regulators, bank regulatory call report filings, and HMDA.

\begin{tabular}{lcccc}
\hline \hline & $\begin{array}{c}\text { Shadow Bank vs } \\
\text { All Bank }\end{array}$ & $\begin{array}{c}\text { Shadow Bank vs } \\
\text { OTD Bank I }\end{array}$ & $\begin{array}{c}\text { Shadow Bank vs } \\
\text { OTD Bank II }\end{array}$ & $\begin{array}{c}\text { Shadow Bank vs } \\
\text { Synthetic } \\
\text { Mortgage Bank }\end{array}$ \\
\cline { 2 - 5 } & $(1)$ & $(2)$ & $(3)$ & $(4)$ \\
\cline { 2 - 5 } Shadow Bank & 36.14 & 27.74 & 28.55 & 33.68 \\
Shadow Bank $\times$ Assets & $(5.34)$ & $(6.49)$ & $(7.48)$ & $(5.34)$ \\
\hline Institution Controls & -1.95 & -1.34 & -1.41 & -1.84 \\
Year FE & $(0.41)$ & $(0.49)$ & $(0.57)$ & $(0.41)$ \\
Observations & Yes & Yes & Yes & Yes \\
R2 & Yes & Yes & Yes & Yes \\
Y-Variable Mean & 109,411 & 10,947 & 8,401 & 109,411 \\
Y-Var Mean SBs & 0.277 & 0.276 & 0.218 & 0.248 \\
Y-Var Mean Bs & 11.56 & 16.73 & 18.99 & 12.47 \\
\hline \hline
\end{tabular}




\section{Appendix A11: Tier 1 Capital Ratio and Size (Assets) - Shadow Banks vs Banks}

This table reports results of OLS regression of the risk-based tier 1 capital ratio on shadow bank indicator, and its interaction with size. The size is measured by the logarithm of assets in dollars (Assets). The sample consists of shadow banks and all banks (Column 1), shadow banks and OTD banks of version I (Column 2), shadow banks and OTD banks of version II (Column 3), shadow banks and synthetic mortgage banks which are constructed by replacing all bank assets with residential mortgages (Column 4). Since shadow banks do not report risk-based tier 1 capital ratios, we compute this ratio by applying the Basel III risk-based tier 1 capital ratio formula. Since we do not observe the detailed risk profiles for each type of assets held on the shadow banks' balance sheet, we use the upper bound and lower bound of shadow banks' tier 1 capital ratios in panel (a) and (b), respectively. These bounds are computed as described in Section 2.D. The OTD banks of version I are defined as banks whose percentage of mortgages sold in less than 1 year as recorded in HMDA in a given year is in the top five percent among all banks. The average percentage of mortgages sold among OTD banks I is $92.4 \%$, while the minimum percentage of mortgages sold is $85.5 \%$. The average percentage of mortgages sold of shadow banks is $94.4 \%$. In column (2) we also remove a few shadow banks whose percentage of mortgages sold is less than the OTD bank I threshold of $85.5 \%$. The OTD banks II are defined as banks whose shares of loans held for sale out of total loans held on balance sheet are greater than $10 \%$ based on their call report data. We note that $10 \%$ share of loans held for sale threshold is broadly consistent with the $85.5 \%$ minimum threshold of mortgages sold out of total originated among OTD banks I (see Section 2E). The synthetic mortgage bank sample is created by replacing all bank loans with mortgage loans while keeping all the other assets fixed. The year-quarter time fixed effects (Date $F E$ ) are included in all specifications. Institution controls include the asset growth, the share of refinanced mortgages out of total mortgage origination volume, the share of government-insured mortgages out of total mortgage origination volume, the logarithm of assets in dollars, the lender's geographic loan dispersion, and the logarithm of the weighted average of income per capita in states of operation, where each state income per capita is weighted by the share of institution $i$ 's loan origination in this state out of total loan origination of institution $i$, as reported in HMDA. The estimated coefficient of the interaction term of shadow bank indicator with assets is scaled by one standard deviation of assets. Standard errors in the parentheses are clustered by institution. Data Sources: Shadow banks' quarterly call report filings to state regulators, bank regulatory call report filings, and HMDA.

Panel A: Tier 1 capital ratio (upper bound)

\begin{tabular}{lcccc}
\hline \hline & $\begin{array}{c}\text { Shadow Bank vs } \\
\text { All Bank }\end{array}$ & $\begin{array}{c}\text { Shadow Bank vs } \\
\text { OTD Bank I }\end{array}$ & $\begin{array}{c}\text { Shadow Bank vs } \\
\text { OTD Bank II }\end{array}$ & $\begin{array}{c}\text { Shadow Bank vs } \\
\text { Synthetic } \\
\text { Mortgage Bank }\end{array}$ \\
\cline { 2 - 5 } Shadow Bank & $(1)$ & $(2)$ & $(3)$ & $(4)$ \\
\cline { 2 - 5 } Shadow Bank $\times$ Assets & 45.57 & 41.30 & 57.49 & 42.21 \\
& $(6.49)$ & $(10.41)$ & $(9.69)$ & $(6.48)$ \\
Date FE & -1.97 & -1.62 & -2.88 & -2.18 \\
Institution Controls & $(0.50)$ & $(0.78)$ & $(0.73)$ & $(0.50)$ \\
Observations & Yes & Yes & Yes & Yes \\
R2 & Yes & Yes & Yes & Yes \\
Y-Variable Mean & 109,411 & 10,947 & 8,401 & 109,411 \\
\multicolumn{1}{c}{ Shadow Banks } & 0.294 & 0.407 & 0.311 & 0.243 \\
\multicolumn{1}{c}{ Banks } & 17.33 & 27.18 & 31.59 & 22.37 \\
\hline \hline
\end{tabular}




\section{Appendix A11: Tier 1 Capital Ratio and Size (Assets) - Shadow Banks vs Banks [continued]}

Panel B: Tier 1 capital ratio (lower bound)

\begin{tabular}{lcccc}
\hline \hline & $\begin{array}{c}\text { Shadow Bank vs } \\
\text { All Bank }\end{array}$ & $\begin{array}{c}\text { Shadow Bank vs } \\
\text { OTD Bank I }\end{array}$ & $\begin{array}{c}\text { Shadow Bank vs } \\
\text { OTD Bank II }\end{array}$ & $\begin{array}{c}\text { Shadow Bank vs } \\
\text { Synthetic } \\
\text { Mortgage Bank }\end{array}$ \\
\cline { 2 - 5 } & $(1)$ & $(2)$ & $(3)$ & $(4)$ \\
\cline { 2 - 5 } Shadow Bank & 25.93 & 23.71 & 39.17 & 22.57 \\
Shadow Bank $\times$ Assets & $(5.31)$ & $(9.83)$ & $(8.61)$ & $(5.28)$ \\
\hline Date FE & -1.26 & -1.10 & -2.31 & -1.47 \\
Institution Controls & $(0.41)$ & $(0.72)$ & $(0.64)$ & $(0.41)$ \\
Observations & Yes & Yes & Yes & Yes \\
R2 & Yes & Yes & Yes & Yes \\
Y-Variable Mean & 109,411 & 10,947 & 8,401 & 109,411 \\
$\quad$ Shadow Banks & 0.139 & 0.240 & 0.194 & 0.082 \\
Banks & 16.77 & 21.85 & 24.20 & 21.80 \\
\hline \hline
\end{tabular}




\section{Appendix A12: Uninsured Bank Leverage and Size (Assets)}

This table reports results of OLS regression of uninsured leverage defined as the uninsured debt to asset ratio on size for shadow banks (panel a) and banks (panel b). The size is measured by the logarithm of assets in dollars (Loan Volume). For shadow banks all debt items are uninsured. For banks uninsured debt is defined as total debt less insured deposits. In panel (b) the sample consists of all banks (Column 1 and 2), OTD banks I (Column 3 and 4), OTD banks II (Column 5 and 6), and synthetic mortgage banks (Column 7 and 8). The OTD banks of version I are defined as banks whose percentage of mortgages sold in less than 1 year as recorded in HMDA in a given year is in the top five percent among all banks. The average percentage of mortgages sold among OTD banks I is $92.4 \%$, while the minimum percentage of mortgages sold is $85.5 \%$. The average percentage of mortgages sold of shadow banks is $94.4 \%$. The OTD banks II are defined as banks whose shares of loans held for sale out of total loans held on balance sheet are greater than $10 \%$ based on their call report data. We note that $10 \%$ share of loans held for sale threshold is broadly consistent with the $85.5 \%$ minimum threshold of mortgages sold out of total originated among OTD banks I (see Section 2E). The synthetic mortgage bank sample is created by replacing all bank loans with mortgage loans while keeping all the other assets fixed. The year-quarter time fixed effects (Date $F E)$ are included in all specifications. Institution controls include the lender's geographic loan dispersion, asset growth, the share of refinanced mortgages out of total mortgage origination volume, the share of government-insured mortgages out of total mortgage origination volume, and the logarithm of the weighted average of income per capita in states of operation, where each state income per capita is weighted by the share of institution $i$ 's loan origination in this state out of total loan origination of institution $i$, as reported in HMDA. The estimated coefficient of assets is scaled by one standard deviation of assets. Standard errors in the parentheses are clustered by institution. Data Sources: Shadow banks' quarterly call report filings to state regulators, bank regulatory call report filings, and HMDA.

Panel A: Debt to asset ratio for shadow banks

\begin{tabular}{lcc}
\hline & \multicolumn{2}{c}{ Shadow Bank } \\
\cline { 2 - 3 } Assets & $(1)$ & $(2)$ \\
\cline { 2 - 3 } & 2.03 & 0.79 \\
& $(0.58)$ & $(0.95)$ \\
\hline Date FE & Yes & Yes \\
Institution Controls & No & Yes \\
Observations & 6,744 & 6,241 \\
R2 & 0.884 & 0.896 \\
Y-Variable Mean & 64.30 & 64.16 \\
\hline \hline
\end{tabular}

Panel B: Uninsured debt to asset ratio for banks

\begin{tabular}{lcccccccc}
\hline \hline & \multicolumn{2}{c}{ All Bank } & \multicolumn{2}{c}{ OTD Bank I } & \multicolumn{2}{c}{ OTD Bank II } & \multicolumn{2}{c}{$\begin{array}{c}\text { Synthetic } \\
\text { Mortgage Bank }\end{array}$} \\
\cline { 2 - 10 } & $(1)$ & $(2)$ & $(3)$ & $(4)$ & $(5)$ & $(6)$ & $(7)$ & $(8)$ \\
\cline { 2 - 10 } Assets & 2.43 & 6.03 & 2.29 & 5.58 & 2.79 & 4.46 & 2.43 & 6.03 \\
& $(0.03)$ & $(0.23)$ & $(0.09)$ & $(0.86)$ & $(0.29)$ & $(1.03)$ & $(0.03)$ & $(0.23)$ \\
\hline Date FE & Yes & Yes & Yes & Yes & Yes & Yes & Yes & Yes \\
Institution Controls & No & Yes & No & Yes & No & Yes & No & Yes \\
Observations & 108,423 & 103,170 & 5,422 & 5,107 & 2.248 & 2,160 & 108,423 & 103,170 \\
R2 & 0.864 & 0.882 & 0.858 & 0.871 & 0.864 & 0.879 & 0.864 & 0.882 \\
Y-Variable Mean & 29.48 & 29.63 & 29.99 & 30.22 & 33.68 & 33.82 & 29.48 & 29.63 \\
\hline \hline
\end{tabular}




\section{Appendix A13: Uninsured Debt Cost and Size (Assets) - Shadow Banks vs Banks}

This table reports regression results of average annual interest rate on shadow bank debt (Column 1 and 2), uninsured bank debt (Column 3 and 4), and an annual uninsured-insured debt interest rate spread for banks (Column 5 and 6), all in percentage points, on size measured by the logarithm of assets in dollars (Loan Volume). We note that all shadow bank debt is uninsured. The annual uninsured-insured interest rate spread is defined as within bank difference between interest rate on uninsured and insured debt. The year fixed effects (Date FE) are included in all specifications. Institution controls include annual asset growth, the share of refinanced mortgages out of total mortgage origination volume, the share of government-insured mortgages out of total mortgage origination volume, the geographic loan dispersion, and the logarithm of the weighted average of income per capita in states of operation, where each state income per capita is weighted by the share of institution $i$ 's loan origination in this state out of total loan origination of institution $i$, as reported in HMDA. The estimated coefficient of assets is scaled by one standard deviation of assets. Standard errors in the parentheses are clustered by institution. Data Sources: Shadow banks' quarterly call report filings to state regulators, bank regulatory call report filings, and HMDA.

\begin{tabular}{lcccccc}
\hline \hline & \multicolumn{2}{c}{$\begin{array}{c}\text { Shadow Bank Sample } \\
\text { Interest Rate }\end{array}$} & \multicolumn{2}{c}{$\begin{array}{c}\text { Full Bank Sample } \\
\text { Interest Rate }\end{array}$} & \multicolumn{2}{c}{$\begin{array}{c}\text { Full Bank Sample } \\
\text { Uninsured-Insured Spread }\end{array}$} \\
\cline { 2 - 7 } & $(1)$ & $(2)$ & $(3)$ & $(4)$ & $(5)$ & $(6)$ \\
\cline { 2 - 7 } Assets & -0.22 & -0.11 & -0.38 & -0.41 & -0.43 & -0.45 \\
& $(0.06)$ & $(0.06)$ & $(0.01)$ & $(0.01)$ & $(0.01)$ & $(0.01)$ \\
\hline Institution Controls & No & Yes & No & Yes & No & Yes \\
Year FE & Yes & Yes & Yes & Yes & Yes & Yes \\
Observations & 2,015 & 1,823 & 27,270 & 27,137 & 27,270 & 27,137 \\
R2 & 0.029 & 0.030 & 0.348 & 0.374 & 0.301 & 0.332 \\
Y-Variable Mean & 4.42 & 3.97 & 2.33 & 2.33 & 1.25 & 1.25 \\
\hline \hline
\end{tabular}




\section{Appendix B: External Validity - Bank Financing Prior to the Deposit Insurance Appendix B1: Bank Leverage Prior to the Deposit Insurance in the United States}

This figure plots the US bank leverage across bank size for US banks active in 1928. Since this time period precedes the establishment of the FDIC fund all bank financing including deposits is uninsured, similarly to modern shadow banks. The size is measured by the logarithm of bank assets. First, these pre-deposit insurance banks are substantially better capitalized than modern banks, with average equity to assets of about 18pp, which is close to the capitalization of shadow banks in our sample. Second, we observe that the extent of cross-sectional dispersion of US banks in the pre-deposit insurance period much closer to those of modern shadow banks and much larger than those of modern banks. Third, consistent with our findings about modern shadow banks, bank leverage (capitalization) increases (decreases) with size for pre-deposit insurance banks. Data Sources: Hand-collected data on funding ratios of more than six thousand US banks active in 1928 provided to us by Aldunate, Jenter, Korteweg, and Koudijs (2019).

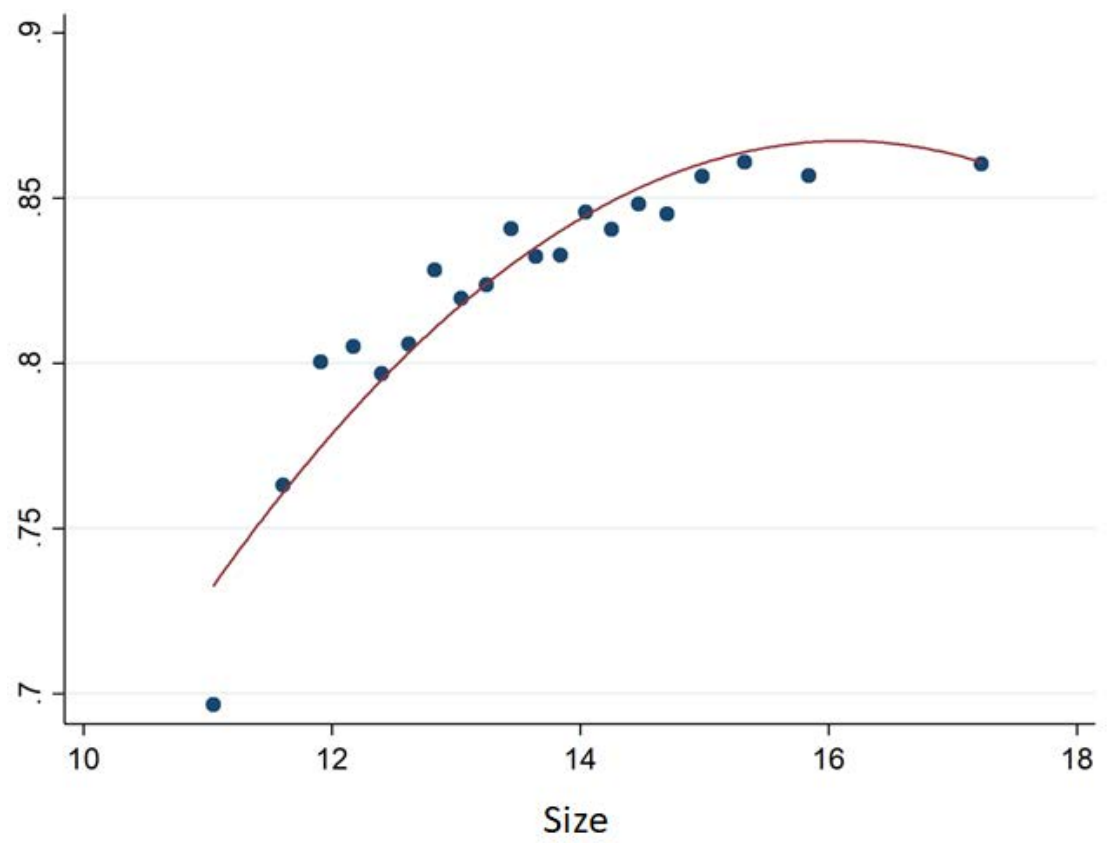




\section{Appendix B2: German Bank Capitalization Prior to the Deposit Insurance}

Panel (a) of this figure plots the distribution (density) of equity to asset ratio for German banks in the period preceding the establishment of deposit insurance. We observe that the extent of cross-sectional dispersion of German bank capitalization in the pre-deposit insurance period is similar to those of modern shadow banks and much larger than those of modern banks. Panel (b) plots the equity to asset ratio across size for German banks in the period preceding the establishment of deposit insurance. The size is measured by the logarithm of bank assets. We observe that consistent with our findings about modern shadow banks, bank leverage (capitalization) increases (decreases) with size. Data Sources: Hand-collected data from the Federal German Archives on 181 unique banks active in 1928-1933 period provided to us by Blickle, Brunnermeier, and Luck (2019).

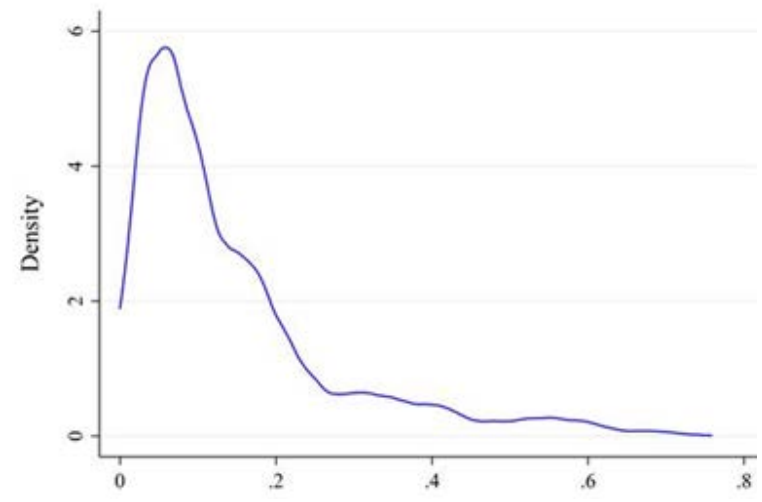

(a) Distribution of Equity to Asset Ratio

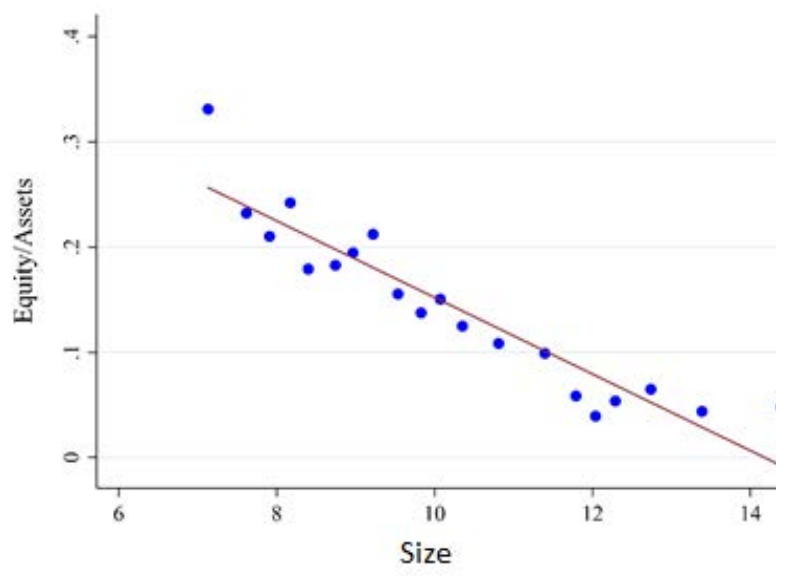

(b) Equity to Asset Ratio and Size 